\title{
GROUND BEETLES (COLEOPTERA, CARABIDAE) IN FUMAROLE FIELDS OF KUNASHIR ISLAND, KURIL ARCHIPELAGO, RUSSIA
}

\author{
Kirill Vladimirovich Makarov ${ }^{1}$, Yurit Nikolaevich Sundukov ${ }^{2}$ \\ and Andrey Vladimirovich Matalin ${ }^{1,3}$ \\ ${ }^{1}$ Moscow State Pedagogical University, Institute of Biology \& Chemistry \\ Zoology E Ecology Department, Kibalchicha str. 6, build. 3, Moscow 129164, Russia \\ E-mail: kvmac@inbox.ru, https://orcid.org/0000-0002-9184-7869 \\ ${ }^{2}$ Federal Scientific Center of East Asia Terrestrial Biodiversity, Zoology Department \\ Laboratory of Entomology, Pr. 100-letiya Vladivostoka 159, 690022 Vladivostok, Russia \\ E-mail:yun-sundukov@mail.ru https://orcid.org/0000-0003-3312-4029 \\ ${ }^{3}$ Pirogov Russian National Research Medical University, Biology Department \\ Ostrovitianova Str. 1, 117997 Moscow, Russia \\ E-mail: andrei-matalin@yandex.ru,https://orcid.org/0000-0002-7790-8709
}

Five species of ground beetles are permanent inhabitants of the fumarola fields on Kunashir Island: Cicindela (Cicindela) sachalinensis A. Morawitz, 1862; Cylindera (Eugrapha) elisae (Motschulsky, 1859); Bembidion (Ocydromus) dolorosum (Motschulsky, 1860); B. (Peryphanes) sanatum Bates, 1883, and Poecilus (Poecilus) samurai (Lutshnik, 1916). These species respond differently to extreme conditions. In some species, the size is decreased (C. elisae, B. dolorosum), but is increased in P. samurai; in B. dolorosum, the pigmentation is decreased, while increased in others (C. sachalinensis, C. elisae, P. samurai). The degree of these variations depends neither on taxonomic relations nor the adaptation time. The areas of moderate thermal activity of Kunashir volcanoes could have served as refugia during the colder climatic periods. Based on data on the variability and barcoding of $B$. dolorosum, the following new synonymy is established: Bembidion (Ocydromus) dolorosum (Motschulsky, 1860) = Bembidion (Ocydromus) negrei Habu, 1958, syn. nov. = Bembidion (Peryphus) kuznetsovi Lafer, 2002, syn. nov.

Keywords: adaptation, Carabidae, extreme conditions, isolation, Russian Far East, volcano.

\section{INTRODUCTION}

The Kunashir Island is the southernmost and one of the largest within the Greater Kuril Chain. It is $123 \mathrm{~km}$ long, 7-30 km wide, and has an area of $1490 \mathrm{~km}^{2}$. The island consists of three mountain blocks formed by four active volcanoes: Tyatya (1819 m) and Ruruy (1485 m) in the north, Mendeleev (889 $\mathrm{m})$ in the centre, and Golovnin $(541 \mathrm{~m})$ in the south. These blocks are separated by the South Kuril and Sernovodsk isthmuses, composed of quaternary marine sediments and volcanic-sedimentary folded Neogene rocks.

Volcanism played and continues to play the leading role in influencing the landscapes on the island. Due to residual volcanism, the soil, water and air in the fumarole fields are enriched with sulfurous compounds; the vegetation 
is strongly depressed and degraded, while the temperature of the soil and above-soil air is markedly increased. As a result, the original landscapes are destroyed, while pioneer or modified habitats are formed.

Although Kunashir Island is the most biodiverse one of the Kuril Archipelago, the study of its carabid fauna started relatively recently: the first information appeared only in the second half of the 20th century (Konakov 1956, HabU 1967, Kuwayama 1967, Kryzhanovskij 1968). These publications contain data about 24 ground beetle species, 20 of which were listed by Kuwayama (1967).

Further research during the last quarter of the 20th century increased the taxonomic diversity of Carabidae of the island to 119 species (KrYvolutsKaja 1973, Kryzhanovskij et al. 1975, 1995, Lafer 1989, 1992). Taking into account all recorded and still unpublished data, the carabid fauna of Kunashir Island currently amounts to at least 180 species (Sundukov, 2001, 2008, 2011, MAKarov et al. 2013, 2019a-b, Makarov \& Sundukov 2011, 2014, 2016, Sundukov \& Makarov 2016, 2019). However, there are no publications on the carabid fauna of the fumarole fields of Kunashir. Only one paper, reports three species on the fumarole fields of the volcanoes of the South Kurils Cicindela sachalinensis A. Morawitz, 1862, Cylindera elisae (Motschulsky, 1859), and Carabus blaptoides rugipennis Motschulsky, 1861 (Konakov 1956).

Thus, the adaptive responses of Carabidae to the extreme conditions of the fumarole fields on Kunashir Island remain to be described, and this is the main objective of the present paper.

\section{MATERIAL AND METHODS}

\section{Research area}

According to the geological morphogenetic classification (Fedorchenкo et al. 1989), active Kunashir volcanoes belong to three types: Tyatya is a single stratovolcano, Ruruy and Mendeleev are isolated "cluster" stratovolcanoes, while Golovnin is a caldera pumicepyroclastic volcano destroyed mainly by erosion and denudation. The latter three volcanoes are presently at a hydrothermal-solfataric stage of activity. Thus, denuded fumarole fields occupy the slopes or calderas of volcanic edifices, with several rivers and streams flowing from there. The temperature of these streams reaches $100{ }^{\circ} \mathrm{C}$, sulphate and sulphate-chloride waters are acidic (minimal pH ca. 2.0), while hydro-carbonate-sulphate sodium-calcium waters are subneutral ( $\mathrm{pH}$ up to 8.5). A detailed description of the studied solfatara fields is given in Appendix 1.

\section{Ground beetle collections}

This study is based on the material taken on Kunashir Island during nine field seasons. The first and third authors, together with I. V. Melnik, A. A. Zaitsev and A. S. Prosvirov (all from Moscow), captured beetles in 2008, 2009, 2011, 2013 and 2017. The second author, together with L. A. Sundukova (Lazo, Primorsky Territory), collected insects from 
mid-May to mid-October 2013-2018. Over that time, more than 200 sites were surveyed (Appendices: Fig. A1) with the following details:

Ruruy Volcano - Neskuchenskie Streams (7-12 August 2013); Dal'nie Streams (21-23 June 2017, 4-9 August 2017).

Mendeleev Volcano - Northeastern solfatara field (19 June 1990, 18 June 2011; 23-24 June 2016, 3-4 August 2016, 22 September 2016, 8 June 2017, 14-16 July 2017).

Golovnin Volcano - caldera (24 June 2008; 11 July 2009; 28 May 2011; 24-28 July 2011; 7-9 June 2013; 14-20 July 2015; 2-11 September 2015; 23-25 June 2016; 30 June-8 July 2016; 23-25 July 2016; 5-10 July 2017; 22-24 June 2018; 16-18 July 2018).

The ground beetles were mainly hand-collected, with occasional pitfall trapping and night sampling. The material was fixed with ethyl acetate or for molecular studies, in $96 \%$ alcohol.

During the entire research period, 15,748 adults belonging to 165 species of ground beetles were collected. Besides, 644 specimens of 44 carabid species from the collection of D. N. Kochetkov (Arkhara, Amur Region), as well as 99 adults of 15 carabid species from the collections of the Federal Scientific Center of East Asia Terrestrial Biodiversity, Far Eastern Branch of the Russian Academy of Sciences, Vladivostok (FEB) and the Zoological Institute of the Russian Academy of Science, St. Petersburg (ZISP) were also studied. Most of the collected individuals are kept in the collections of the FEB and Moscow State Pedagogical University, Moscow (MPU); several specimens were transferred to the collections of the Zoological Museum of the Moscow State University, Moscow (ZMMU) and ZISP. The details are as follows (all labels are shown in Appendix 2.):

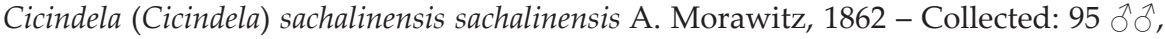

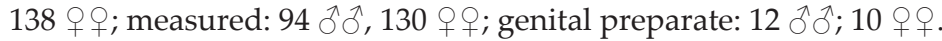

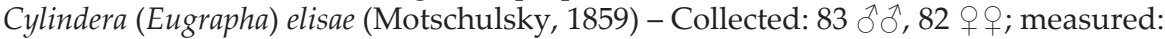
$83 \hat{\jmath} \hat{\jmath}, 82$ 우; genital preparate: $29 \hat{\jmath}$ ô; 6 우.

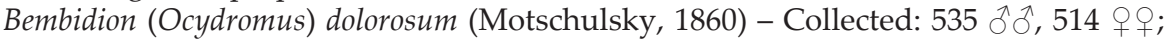

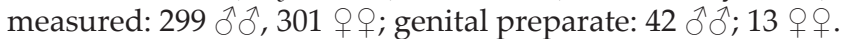

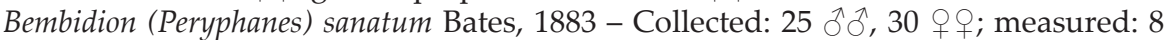

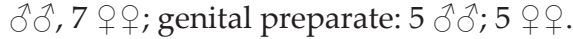

Poecilus (Poecilus) samurai (Lutshnik, 1916) - Collected: 67 के $\hat{\sigma}, 54$ 우우; measured: 50 $\hat{\partial} \hat{\sigma}, 37$ q 0 ; genital preparate: $9 \hat{\delta} \widehat{\partial}$.

Specimens were examined under MBS-1 or Leica M165C stereoscope, the slides of male genitalia studied under a Zeiss Axio Scope.A1 microscope, and photographed with a Canon EOS 5D Mark III camera with a Canon MP-E $65 \mathrm{~mm}$ macro lens, or a Canon EOS 6D camera attached to a Zeiss Axio Scope.A1 microscope. In both cases, the extended focus technique was used, and photos were processed using the Zerene Stacker software. For preparing the slides, the aedeagi of some male specimens were consistently kept in $10 \%$ $\mathrm{KOH}(24 \mathrm{~h}$.), $4 \%$ acetic acid ( $5 \mathrm{~min}$.) and cold water (5 min.), and then mounted with Hoyer fluid or Euparal (D 1.05) media.

\section{DNA extraction and amplification}

The genetic studies were carried out at the Natural History Museum, University of Oslo. DNA was extracted from the prothorax, hind legs or testis accessory gland from specimens previously fixed in absolute alcohol, using the Qiagen DNeasy Blood \& Tissue Kit $^{\circledR}$ (QIAGEN, Hilden, Germany) following the manufacturer's protocol for animal tissue, 
with minor modifications (ELven et al. 2010). The voucher specimens and the DNA extracts are deposited in the collection of MPU.

Samples were incubated in lysis buffer ATL and proteinase $\mathrm{K}$ at $55^{\circ} \mathrm{C}$ for $24 \mathrm{~h}$. A region of $\sim 700 \mathrm{bp}$ from the mitochondrial cytochrome oxidase subunit I (COI) was amplified with both forward primer LCO 1490 and reverse primer HCO 2198 (Folmer et al. 1994). PCR was performed in a $25 \mu$ reaction volume using $14 \mu \mathrm{l}$ Master Mix $1\left(8.76 \mu \mathrm{l} \mathrm{dsH_{2 }} \mathrm{O}_{\text {, }}\right.$ $0.24 \mu \mathrm{l}$ BSA, $2.5 \mu \mathrm{l}$ GeneAmp dNTP Mix, $1.25 \mu \mathrm{l}$ of each primer), $8 \mu$ l Master Mix 2 (5.375

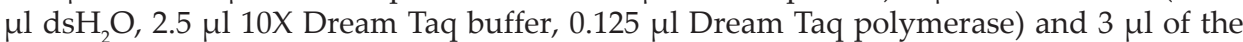
respective DNA extract.

The general PCR profile consisted of an initial activation step at $95^{\circ} \mathrm{C}$ for $2 \mathrm{~min}$, followed by 34 amplification cycles consisting of $95^{\circ} \mathrm{C}$ for $30 \mathrm{~s}$ (denaturation), $49^{\circ} \mathrm{C}$ for $30 \mathrm{~s}$ (annealing) and $72{ }^{\circ} \mathrm{C}$ for $1 \mathrm{~min}$ (extension), and a final extension step of $72{ }^{\circ} \mathrm{C}$ for $10 \mathrm{~min}$. The success of the PCR was ascertained in a 1\% agarose gel in TAE buffer, and FastRuler Low Range DNA Ladder was used as the molecular weight marker.

The PCR products were purified using ExoSAP $45^{\circledR}$ protocol (USB Corporation, Cleveland, Ohio, USA), and then all fragments were sequenced in both directions either externally by the StarSEQ (Mainz, Germany).

\section{Sequence alignment}

The nucleotide sequences obtained were manually edited to correct possible sequencing errors and to delete low-resolution terminal segments using the Unipro UGENE v33.0 (Окоnеснniкov et al. 2012) and then aligned in MEGA-X v10.1.6 using the MUSCLE algorithm (Kumar et al. 2018). Ambiguously aligned regions were excluded from the downstream analyses. The edited nucleotide sequences were deposited in GenBank under accession numbers MW240488-MW240502.

\section{Phylogenetic analysis}

To clarify the taxonomic status of the particular populations of Cylindera (Eugrapha) elisae (Motschulsky, 1859) from different Kunashir Island localities, additional C. elisae sequences from GenBank from various localities in Japan, Korea and Taiwan were used, and the sequences from GenBank corresponding to specimens of $C$. (E.) bonina (Nakane et Kurosawa, 1959) were also applied to the analysis as outgroup. A haplotype network to visualize the relationships among haplotypes for the C. elisae sequence dataset was calculated using PopART v.1.7 (Leigh \& Bryant 2015). A Minimum spanning network was constructed with default settings for the aligned haplotype sequences (BANDELT et al. 1999).

To confirm the conspecificity of Bemdidion (Ocydromus) dolorosum (Motschulsky, 1860) and B. (Ocydromus) negrei Habu, 1958, additional sequences from GenBank corresponding to ten species of the subgenus Ocydromus Clairville, 1806 were also included (see Appendix 3).

The evolutionary analysis was inferred by using the Maximum Likelihood method and Kimura 2-parameter model (Kimura 1980, TAmura et al. 2012). Initial tree(s) for the heuristic search were automatically obtained by applying Neighbor-Join and BioNJ algorithms to a matrix of pairwise distances estimated using the Maximum Composite Likelihood (MCL) approach, and then selecting the topology with the superior log likelihood value. This analysis involved 113 nucleotide sequences. A total of 849 positions were in the final dataset. Evolutionary analyses were conducted in MEGA X (KumAr et al. 2018). 


\section{Measurements}

The measurements (in $\mathrm{mm}$ ) were made with an ocular-micrometer mounted on a Leica M165c (Carl Zeiss) stereo microscope, as follows: CI - confidence interval; EL greatest length of elytra; EW - greatest width of elytra; Lae - length of the aedeagus; Llm2 - length of lamina 2; Lms - length of main sclerite; PLm - length of pronotum, measured along the median line; PW - greatest width of pronotum; TL - total body length without labrum (from anterior margin of clypeus to the elytral apex along the suture). The nomenclature of the sclerites of the male internal sac in Bembidion follows BeLousov and Sokolov (1996), as well as Neri and Vigna TAglianti (2010).

\section{Data analysis}

Statistical analysis was performed using the PAST v4.0 software (HAmmer et al. 2001). The significance was determined by Tukey's and Mann-Whitney $U$-test for independent variables, with a $95 \%$ confidence interval. If statistically significant differences were found, pairwise Dunn's a posteriori tests were additionally executed. Frequencies of colour variants were analysed by Mann-Whitney and $\chi^{2}$ tests. The influence of temperature and $\mathrm{pH}$ was assessed using a multivariate multiple linear regression analysis.

\section{RESULTS AND DISCUSSION}

A total of 846 specimens belonging to 29 species of ground beetles (Appendix 4) were collected in the fumarole fields, but only five species (780 specimens) were permanent inhabitants of these unusual habitats.

\section{Cicindela (Cicindela) sachalinensis sachalinensis}

Cicindela sachalinensis occurs in eastern and central China, Korea, eastern Mongolia, the Russian Far East, and Japan (Wiesner 1992, Puchкov \& Matalin 2003, 2017). Among the five subspecies, the nominal one is known exclusively from insular habitats of Sakhalin, Moneron, Iturup, Kunashir, Shikotan (Kryzhanovskij et al. 1975, 1995, LAFER 1978, 1999, MaKarov et al. 2020), Hokkaido and Honshu (Wiesner 1992, Puchkov \& Matalin 2003, 2017). This species is widely distributed over the Kunashir Island (Appendices: Fig. A13) and is mostly observed in habitats without or only with scant plant cover (Kryzhanovskij et al. 1975, LAFER 1978, 1999, MaKarov et al. 2019b, this paper). It was present in almost all fumarola fields studied (Appendices: Fig. A8) but recorded in high numbers only in Golovnin Volcano on the fumaroles of the central domes. The specimens inhabiting the fumarole fields were similar in size to specimens from other habitats, except for the significantly smaller females (Figs 9A, B). On the fumaroles, significantly more $(\mathrm{p}<<0.01)$ dark-pigmented adults were collected (Fig. 8A, Appendices: Figs A18, A19). 


\section{Cylindera (Eugrapha) elisae}

Cylindera elisae is an Asiatic tiger beetle occurring from the Amur River valley through Mongolia, Korea and China (Puchкov \& Matalin 2003, 2017) to northern Vietnam (WIESNER et al. 2017), and also in Sakhalin, Kunashir, Taiwan and various Japanese islands. On Kunashir Island, this species is found only on fumarole fields of two volcanoes (Appendices: Figs A9, A12). One form, C. e. kunashirensis Pütz et Wiesner, 1994, inhabits the valley of Kislaya River on the Mendeleev Volcano (KrYZHAnovskij et al. 1975, LAfER 1978, PüTZ \& Wiesner 1994, Sabirov et al. 2014, Makarov et al. 2019b, Sundukov \& MaKAROv 2019), while a different form populates the Neskuchenskiye Streams on the Ruruy Volcano (Makarov et al. 2019b, Sundukov \& Makarov 2019). The specimens from these localities are well distinguishable by size, the proportions of the labrum, and elytral coloration. Thus, C. e. kunashirensis is smaller: in males, $\mathrm{TL}=8.74 \mathrm{~mm}[\mathrm{CI}=7.8-9.2 \mathrm{~mm}]$ vs. $9.38 \mathrm{~mm}[\mathrm{CI}=8.55-10.05 \mathrm{~mm}]$ in the specimens from the Ruruy Volcano ( $\mathrm{p} \ll 0.01$ ), in females, $\mathrm{TL}=9.81 \mathrm{~mm}$ $[\mathrm{CI}=8.6-10.6 \mathrm{~mm}]$ vs. $10.19[\mathrm{CI}=8.8-11.3 \mathrm{~mm}]$ in specimens from the Ruruy Volcano $(\mathrm{p}<0.05)$. Besides, C. e. kunashirensis shows a significantly $(\mathrm{p}<<0.001)$ narrower labrum, darker elytra (Figs $1 \mathrm{~A}-\mathrm{F}$ ), and darker elytral punctation. The barcoding technique also verified the distinction of C. e. kunashirensis. According to the data obtained, specimens from the Kislaya River formed a compact cluster clearly separated from most other local forms of C. elisae (.2), their haplotypes being separated from the basic one by 206 mutational steps. By the white pattern on the elytra (Figs 1B, H), as well as the shape of the aedeagus (Figs 1G-L), specimens from the Ruruy Volcano are more similar to those from Sakhalin and the continental Russian Far East than to C. e. novitia, the latter inhabiting northern Hokkaido. All these observations allow us to conclude that the Ruruy specimens belong to the nominative subspecies. Interestingly, in the Japanese sub-prefecture of Nemuro, where the eastern coast of the Shiretoko Peninsula is $24-43 \mathrm{~km}$ from the Kunashir Island, C. elisae has not yet been recorded (Кімото \& Yasuda 1995).

\section{Bembidion (Ocydromus) dolorosum}

Bembidion dolorosum is widespread in Japan (Hokkaido, Honshu), also inhabiting southern Sakhalin (north to Dolinsk, 47 $19^{\prime}$ ) and Moneron Island, as well as the southern Kuriles (Urup, Iturup, Kunashir, Shikotan, and islands of the Lesser Kuril Chain) (NAKANe 1963, INOuYe 1971, KrYZHANOvsKiJ et al. 1975, Watanabe 1989, Lafer 1998, 2002a, 2006, Yoshitake et al. 2011, Sundukov 2017, Sundukov \& Makarov 2013, 2016, Makarov et al. 2019b). On Kunashir Island, it occurs on the banks of almost all rocky or sandy rivers and streams 
(Appendices: Fig. A14), in all fumarola fields studied (Appendices: Figs A2, A4, A6), sometimes in very high numbers. In fumarolas, we observed it feeding on small dead insects, mostly flies (Appendices: Figs A10, A11).
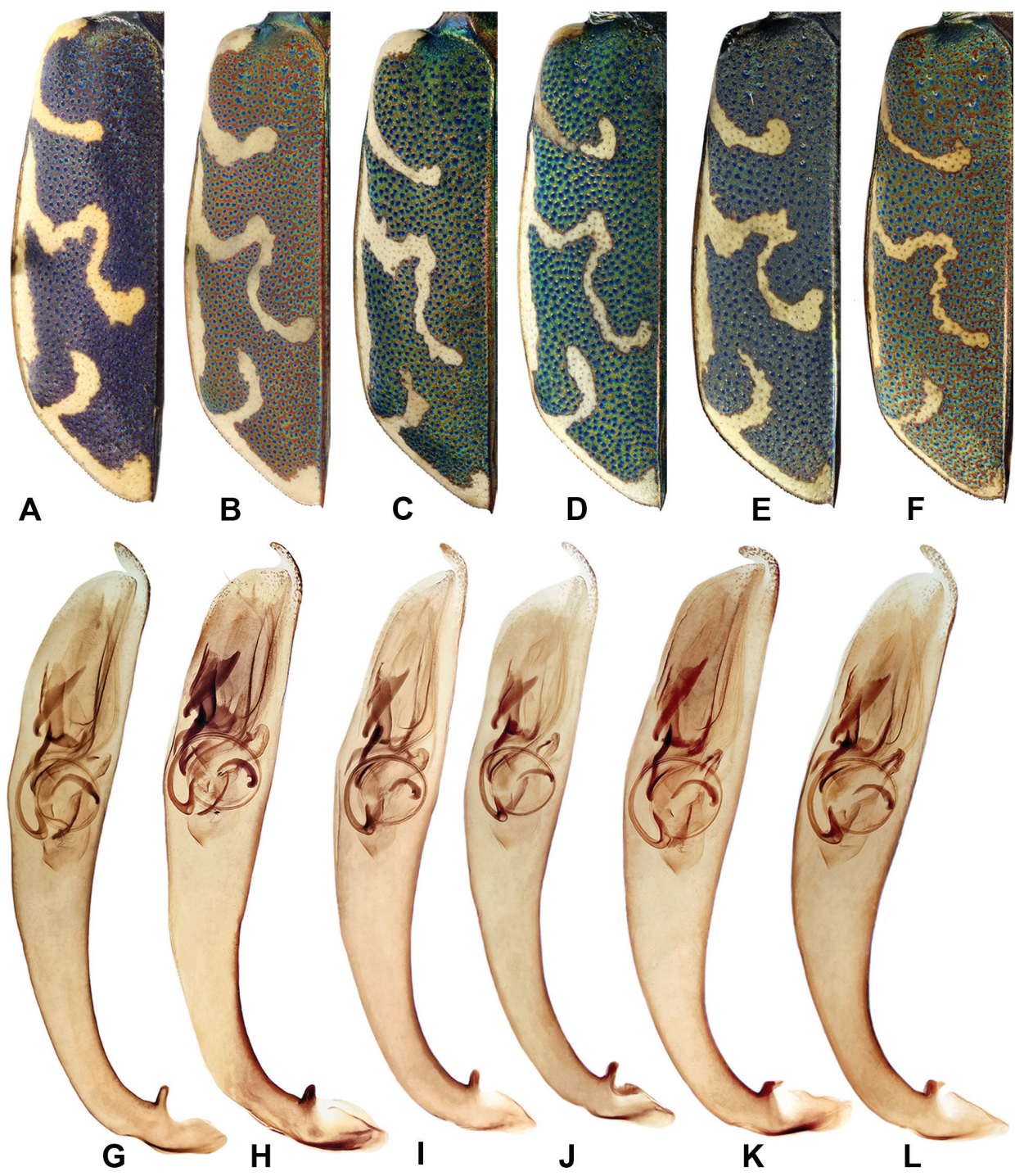

Fig. 1. Males of C. elisae: $A, G=C$. elisae kunashirensis (Kunashir Isl., Kislyi Stream); B-D, $\mathrm{H}-\mathrm{J}=$ C. elisae elisae (B, H = Kunashir Isl., Neskuchenskie Streams; C = Sakhalin Isl., Susuya River; D = Khabarovsky Krai, Korsakovo; I = Sungari River; J = Primorsky Krai, Kedrovaya Pad' National Reserve); E, $\mathrm{K}=\mathrm{C}$. elisae novitia (Japan, Ishigaki); F, L = C. elisae mikurana (Japan, Kozushima); A-F = left elytron; G-L = aedeagus, left lateral view 
In the northern part of the distribution area (Sakhalin and Kuril Islands), B. dolorosum is characterized by moderate variability and a clear-cut sexual dimorphism (Figs 10A, B). In males, $\mathrm{TL}=5.19 \mathrm{~mm}[\mathrm{CI}=5.14-5.23 \mathrm{~mm}]$, in females, $\mathrm{TL}=5.35 \mathrm{~mm}[\mathrm{CI}=5.30-5.39 \mathrm{~mm}]$. The proportions of the head and pronotum are slightly variable. The differences between the populations from different islands are usually not significant, only the males from Yuriy Island and the females from Sakhalin Island in most cases differ significantly.

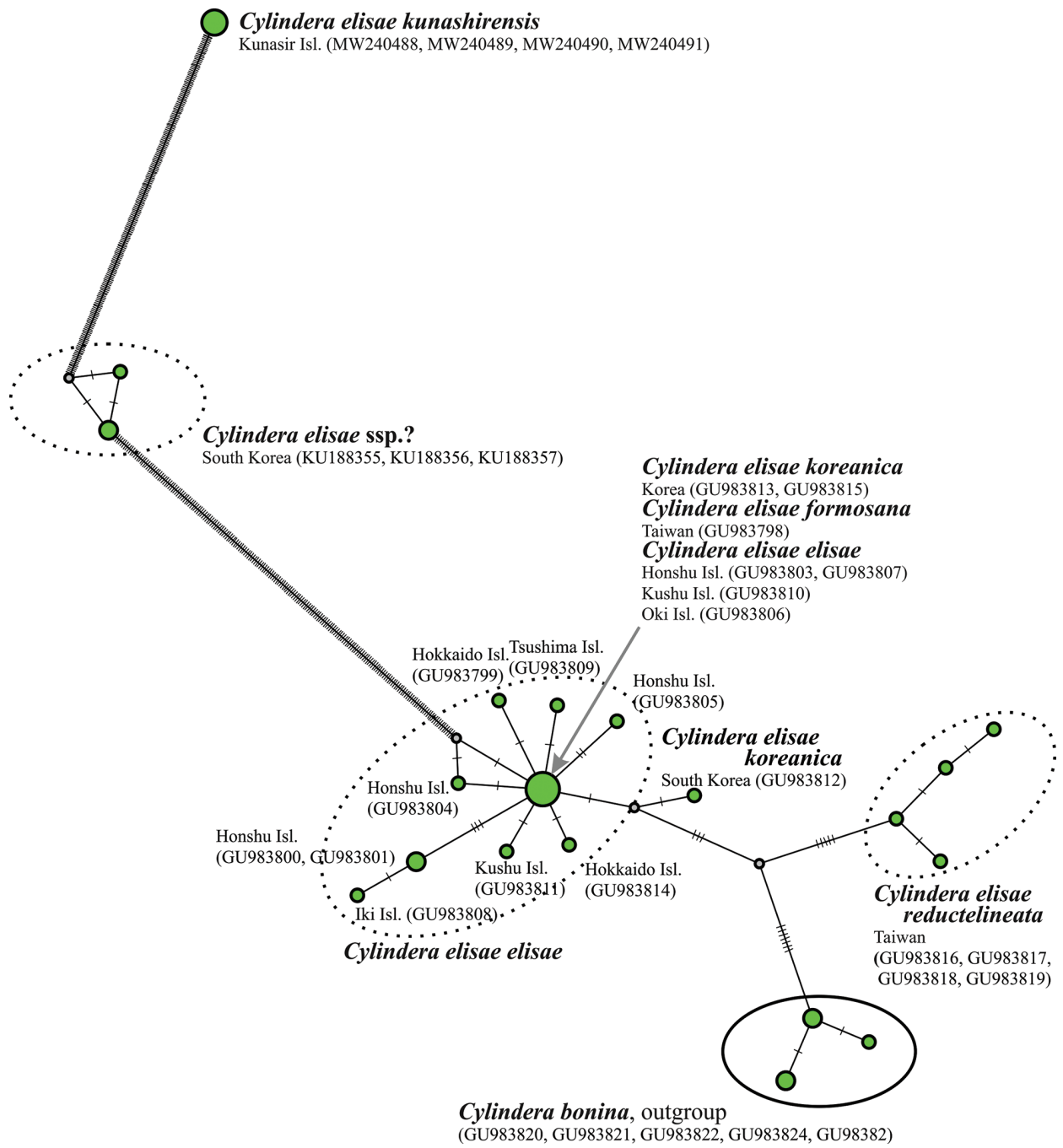

Fig. 2. Position of Cylindera elisae kunashirensis in the Cylindera elisae haplotype network (minimum spanning network, mutations show as hatch marks, GenBank accession numbers for each isolate indicated in brackets) 
Specimens living in the fumarole fields of the Kunashir Island are significantly $(\mathrm{p}<0.01)$ smaller than elsewhere; in males, $\mathrm{TL}=4.76 \mathrm{~mm}[\mathrm{CI}=4.69-4.82$ $\mathrm{mm}]$, in females, $\mathrm{TL}=4.87 \mathrm{~mm}[\mathrm{CI}=4.81-4.94 \mathrm{~mm}]$, and the sexual dimorphism is less pronounced. Beetles from the fumarole fields also differ by a decreased elytral pigmentation (Fig. 3, Appendices: Figs A10, A20-A39, A40-A64), an increased pronotum and elytra (Figs 10C, D), as well as by shorter claws and the ventro-apical setae of the tarsomeres (Appendices: Figs A65-A67).

These demonstrate clinal variability, because the body size, coloration and main body proportions gradually changed under an environmental acid-
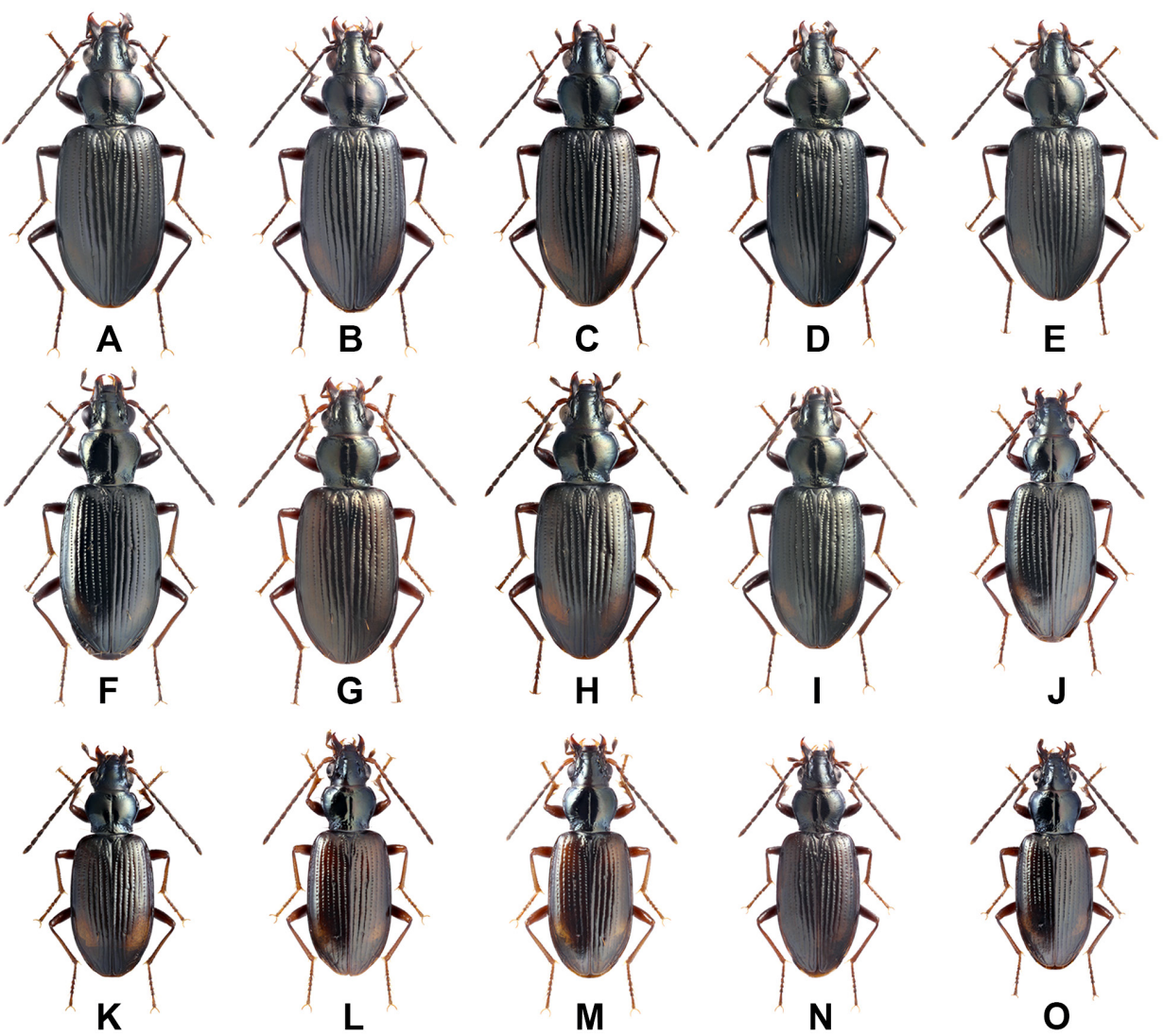

Fig. 3. Variability B. dolorosum, females: A = Kunashir Isl., mouth of the Ozernaya River; B = Kunashir Isl., mouth of the Mednyi Stream; C = Sakhalin Isl., near Khomutovo; D = Sakhalin Isl., Rogatka River; E = Kunashir Isl., caldera of Golovnin Volcano, near cordon Ozernyi; F = Yuriy Isl., Shirokaya Bay; G = Kunashir Isl., Mendeleev Volcano, mouth of Kislyi Stream; H, K = Kunashir Isl., Dokuchaeva Mt. Ridge, solfatara field "Bolshoye"; I = Shikotan Isl., Tserkovnaya Bay; J, L, O = Kunashir Isl., caldera of Golovnin Volcano, solfatara field "Cherepakhovoye"; M = Kunashir Isl., Mendeleev Volcano, source of Kislyi Stream; $\mathrm{N}=$ Kunashir Isl., caldera of Golovnin Volcano, Kipyashcheye Lake (loc. typ. B. kuznetsovi) 

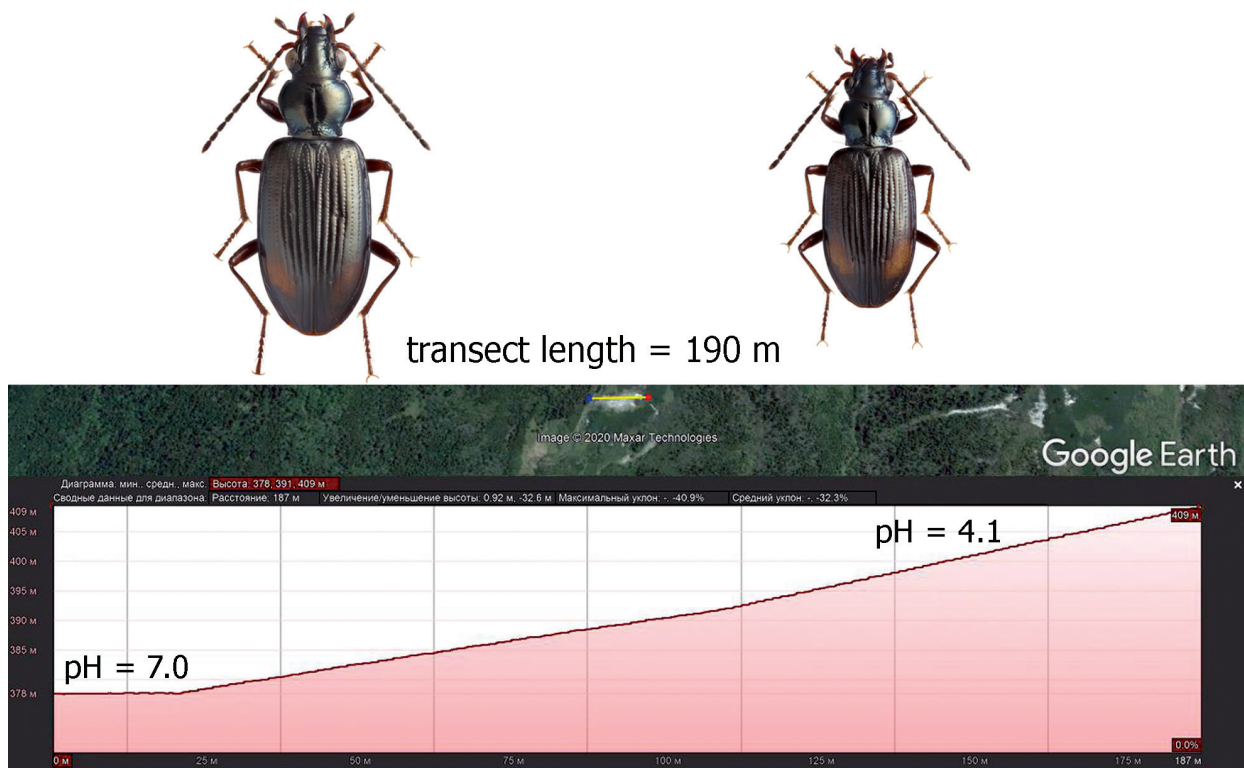

A
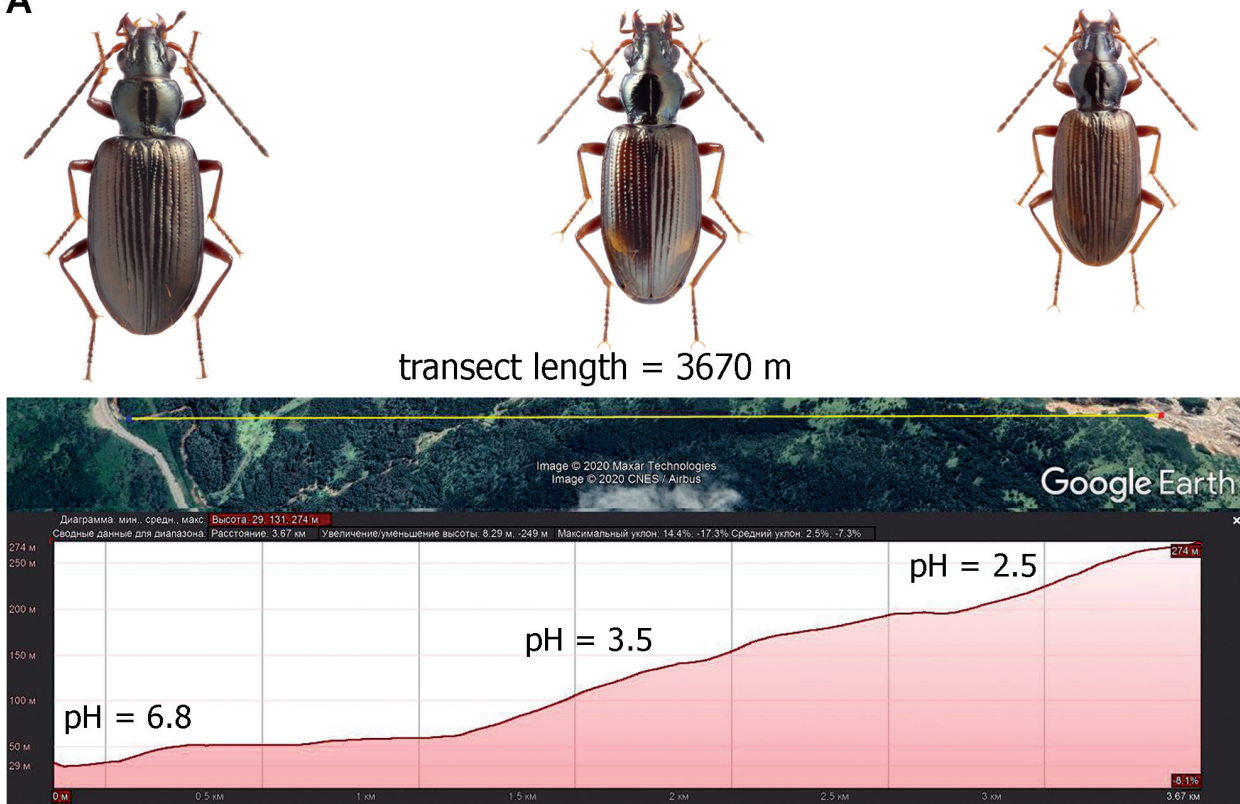

B

Fig. 4. Size and color variability $B$. dolorosum with an increase in the acidity of watercourses: A = Kunashir Isl., Dokuchaeva Mt. Ridge, solfatara field "Bolshoye"; B = Kunashir Isl., Mendeleev Volcano, Kislyi Stream 
ity gradient. Along transects with a moderate gradient, these changes are relatively small (Fig. 4A), but is more pronounced under greater range (Fig. 4B). There was a significant dependence of body length and the proportions of the pronotum on both temperature and water acidity (multiple linear regression, Wilks lambda $=0.4075 ; \mathrm{F}=84.12 ; \mathrm{p}=1.401 \times \mathrm{E}-56$; see Appendix 5).

Interestingly, the structure of the aedeagus also varied. In males living under increased temperature and acidity, the aedeagus became relatively enlarged, vs. the endophallus sclerites (main sclerite $=$ sclerite principale and lamina 2 = lama paracopulatrice) relatively shortened (Figs 5, 6; Appendices: Figs A68A88, A89-A94).

The COI sequences of the specimens inhabiting the fumarola fields and other habitats were identical or differed only by 1-2 mutation steps. All specimens formed a compact cluster on the Ocydromus phylogenetic tree (Appen-

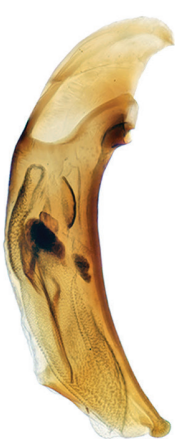

A

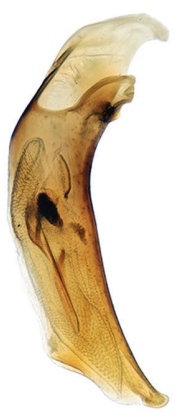

H

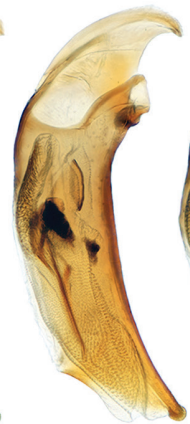

B

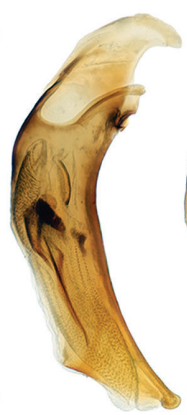

I

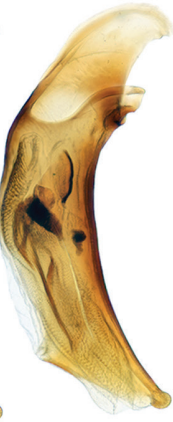

C

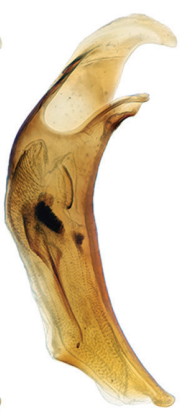

J

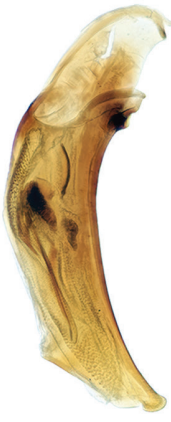

D

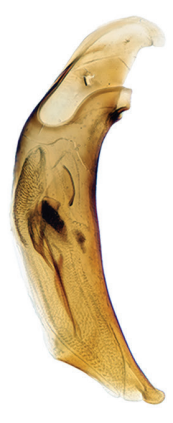

K

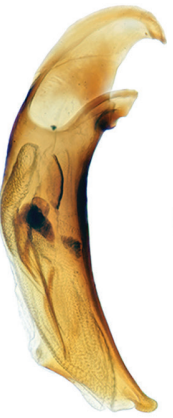

E

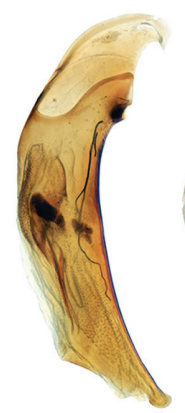

L

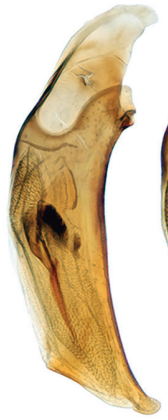

F

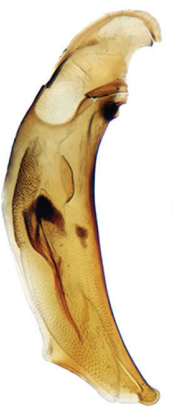

M

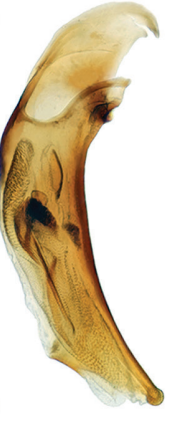

G

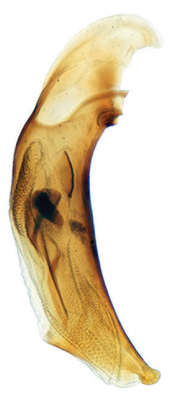

N

Fig. 5. Variability of the shape and size of the aedeagus B. dolorosum: A, E = Shikotan Isl., Tserkovnaya Bay; B = Kunashir Isl., Zmeinyy (Stolbovskoy) Stream; C = Kunashir Isl., mouth of the Ozernaya River; D = Kunashir Isl., Mendeleev Volcano, mouth of Kislyi Stream; F, H, K = Kunashir Isl., Mendeleev Volcano, source of Kislyi Stream; G = Kunashir Isl., caldera of Golovnin Volcano, Kipyashcheye Lake (loc. typ. B. kuznetsovi); I, J = Yuriy Isl., Shirokaya Bay; L, N = Kunashir Isl., caldera of Golovnin Volcano, solfatara field "Cherepakhovoye"; M = Kunashir Isl., Dokuchaeva Mt. Ridge, solfatara field "Bolshoye" 
dices: Fig. A95). D. Maddison (pers. comm.) has sequenced six genes (COI, 28S, wingless, CAD, topoisomerase, and Muscle-Specific Protein 300 (MSP)) for one specimen of the B. dolorosum form (from the Shiretoko Peninsula, Hokkaido Isl.) and one specimen we provided of the fumarole from the caldera of Golovnin Volcano, Kunashir Isl. These two specimens had identical sequences in COI, 28S, and differed by a single base (among 487 bases) in wingless, one base (among 767 total bases) in CAD, four bases (among 876 bases) in topoisomerase, and two bases (among 765 bases) in MSP.

Note. LAfer (2002b) described Bembidion (Peryphus) kuznetsovi from the bank of Lake Kipyashcheye and compared his new species to Bembidion (Pery-
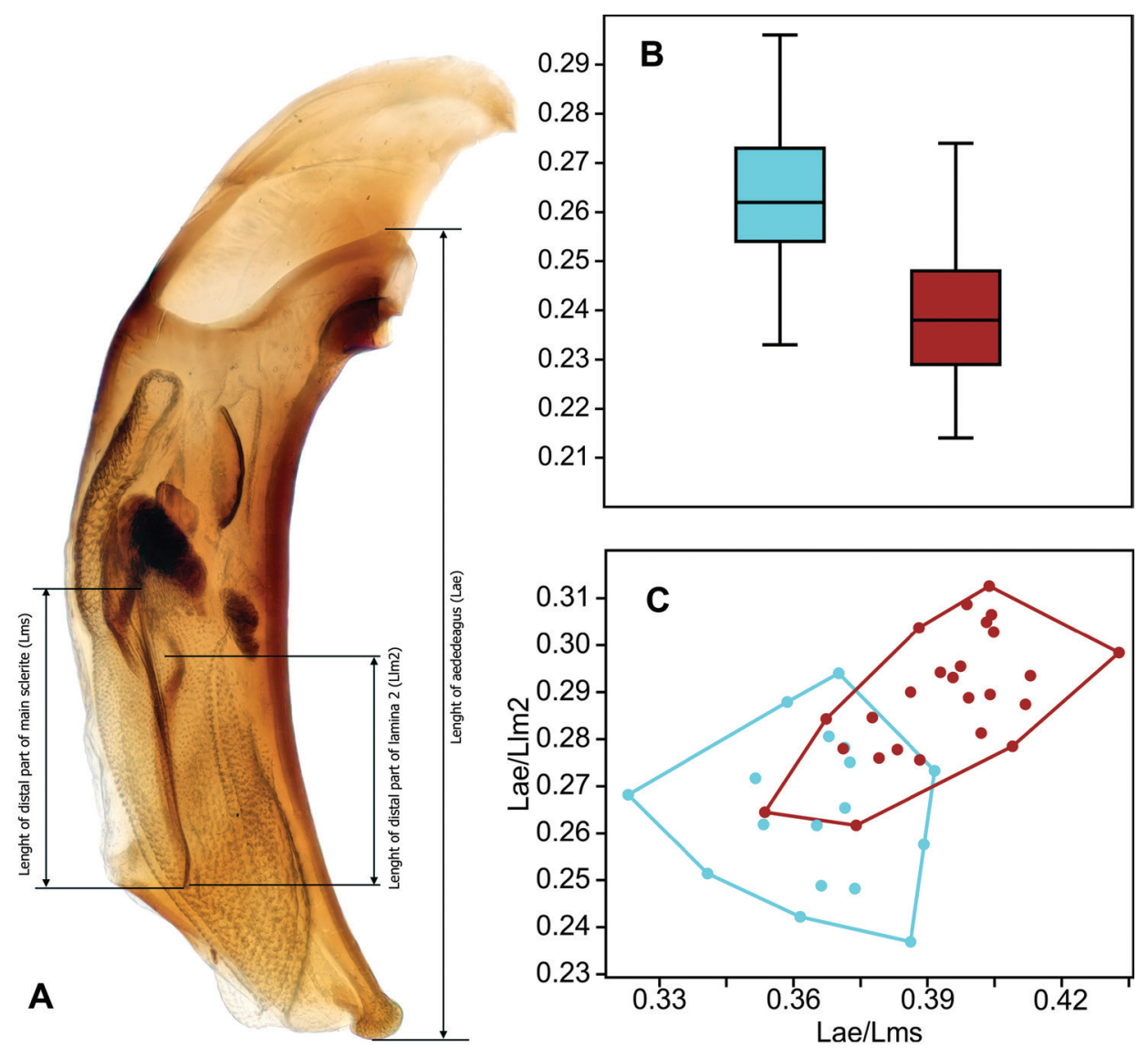

Fig. 6. Variability of the proportions of the aedeagus and its sclerites in B. dolorosum: $\mathrm{A}=$ measurement scheme; $\mathrm{B}=$ relative length of the aedeagus; $\mathrm{C}=$ relative length of main sclerite and lamina 2. Cyan = individuals inhabiting solfataric fields, brown = living under ordinary conditions 
phus) poppii pohlai Kirschenhofer, 1984 and Bembidion (Terminophanes) consummatum Bates, 1873, but not to B. dolorosum. Later, Morita (2010) studied some species of Bembidion inhabiting fumarola fields on Hokkaido and northern Honshu and established the synonymy B. kuznetsovi with Bembidion (Ocydromus) negrei Habu, 1958. According to the data obtained, we establish here the following new synonymies: Bembidion (Ocydromus) dolorosum (Motschulsky, 1860) = Bembidion $($ Ocydromus) negrei Habu, 1958 syn. nov. = Bembidion (Peryphus) kuznetsovi Lafer, 2002 syn. nov. It is noteworthy that the diagnostic features of Bembidion (Ocydromus) ozakii Morita, 2010, described by Morita (2010) from Japan, entirely correspond to the individual variation range of $B$. dolorosum. Thus, B. ozakii is probably only another synonym of $B$. dolorosum as well.

\section{Bembidion (Peryphanes) sanatum}

This species is widely distributed in different habitats over a wide altitudinal range on the Japanese islands of Hokkaido and Honshu (BATEs 1883, JedličKa 1965, Watanabe 1989, Kimoto \& Yasuda 1995, Yasui \& Shiyake 2008, Yoshitake et al. 2011, Mori 2016, Yoshimatsu et al. 2018), but in the Kunashir Island, it was found only on the slopes of the Mendeleev Volcano (Appendices: Fig. A15), in the valley of Kislaya River (KrYzhanovskij et al. 1975, SunDukov \& Makarov 2016, Makarov et al. 2019b, our data). The beetles inhabit the bank of an acidic mineralized stream flowing down from fumarola fields (Appendices: Fig. A4). It noteworthy that these fumarola fields and streams are also the sole habitat for the endemic Kunashir tiger beetle, Cylindera elisae kunashirensis.

Notes. In the original description, BATEs (1883) considered B. sanatum as closer to the European B. lunatum (Duftschmid, 1812). Later authors placed this species to the subgenus Peryphus Dejean, 1821 (Netolitzky 1943, JedLičKA 1965, Kirschenhofer 1984), while others to Bembidion incertae sedis (MARGGI et al. 2017). Based on the structure of the male aedeagus and female spermatheca, B. sanatum belongs to Peryphanes (Sundukov \& MaKarov 2016). Most species of this subgenus are restricted to the western Palaearctic. In eastern Asia, only five species are known to occur (JEDLIČKa 1933, HABU \& UÉNo 1955, Habu 1973, NaKane 1979, Kirschenhofer 1984), which are recorded from Japan (B. dostali Kirschenhofer, 1984; B. hayachinense Nakane, 1979; B. hikosanum Habu et Uéno, 1955), China (B. parepum Jedlička, 1933) or Taiwan (B. lulinense Habu, 1973). Originally, all those species were described in different subgenera, and only recently were they all classified as Peryphanes (Toledano 2009, 2011, MARGgi et al. 2017). Based on the conformation of the spermatheca (a large number of whorls of a sclerotized vas deferens, the proportions and shape of the chambers), as well as structure of the aedeagus (large lateral scle- 
rites, large basal sclerites protruding far from the base, the absence of a ventral tubercle), B. sanatum is very similar to the western Palaearctic Bembidion (Peryphanes) stephensii Crotch, 1866 (Fig. 7).

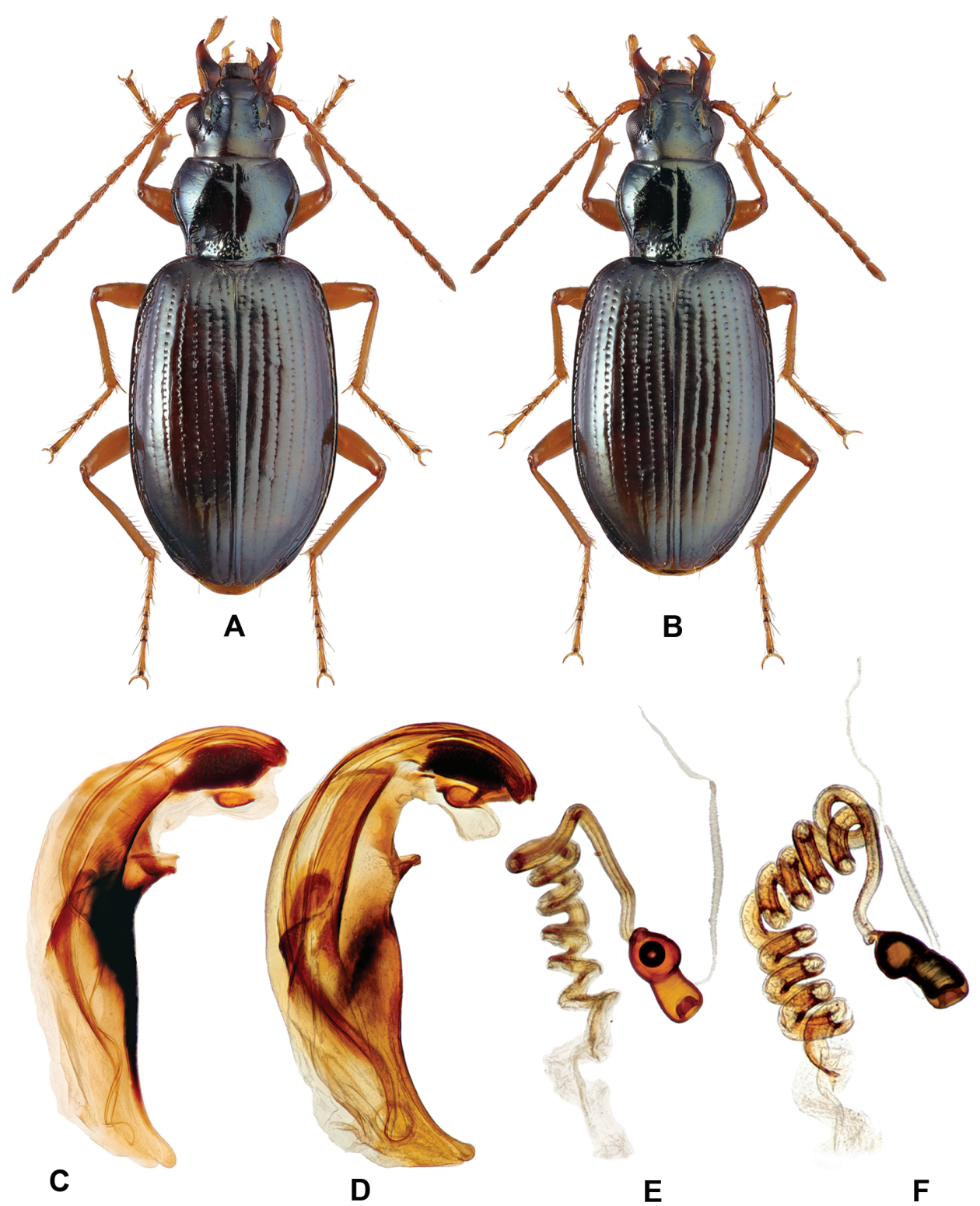

Fig. 7. Bembidion sanatum and B. stephensii: $\mathrm{A}-\mathrm{C}, \mathrm{E}=\mathrm{B}$. sanatum; $\mathrm{D}, \mathrm{F}=\mathrm{B}$. stephensii; $\mathrm{A}, \mathrm{B}=$ dorsal habitus, male and female; $\mathrm{C}, \mathrm{D}=$ aedeagus; $\mathrm{E}, \mathrm{F}=$ spermatheca 


\section{Poecilus (Poecilus) samurai}

On Kunashir Island, this species lives in open habitats such as forest edges and clearings, as well as meadows, including sites with dense and tall grass (Lafer 1989, Makarov et al. 2019b, this paper). As a rule, it does not co-occur together with the closely related Poecilus (Poecilus) fortipes (Chaudoir, 1850) (Appendices: Figs A16, A17). In fumarole habitats, P. samurai was observed only on the Dokuchaev Mountain Ridge ("Bolshoye" fumarola field, Appendi-

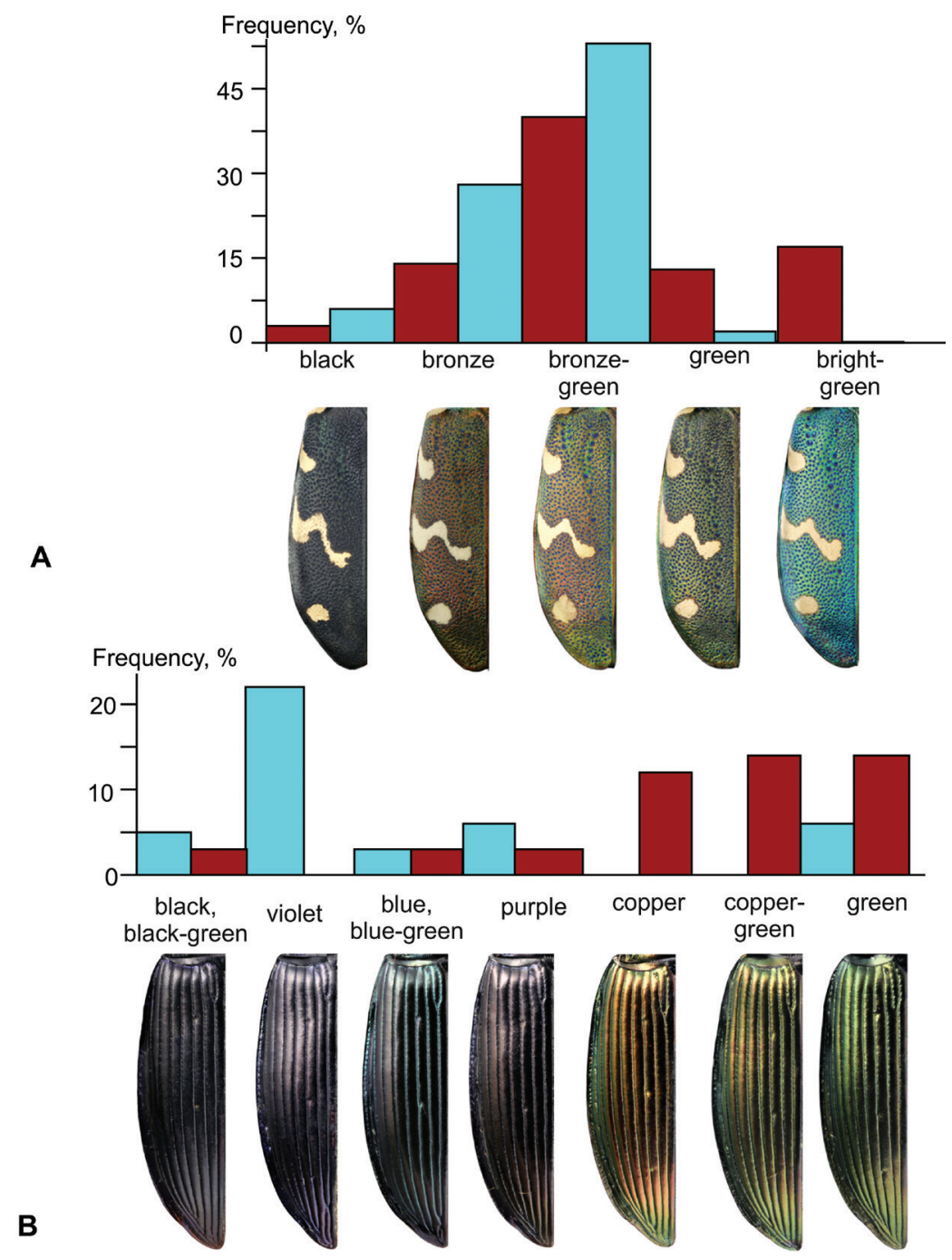

Fig. 8. Variability coloring Cicindela sachalinensis (A) and Poecilus samurai (B) on Kunashir Island . Cyan = specimens from fumarole fields; brown = specimens from common habitats 
ces: Fig. A3). These specimens significantly $(\mathrm{p}<0.01)$ differed from others both by their larger size (Fig. 9D) and the higher level of cuticular melanization (Fig. 8B, Appendices: Figs A96-A97 vs. A98-A99). However, the structure of the internal sack of the aedeagus was not different (Appendices: Figs A100-103).
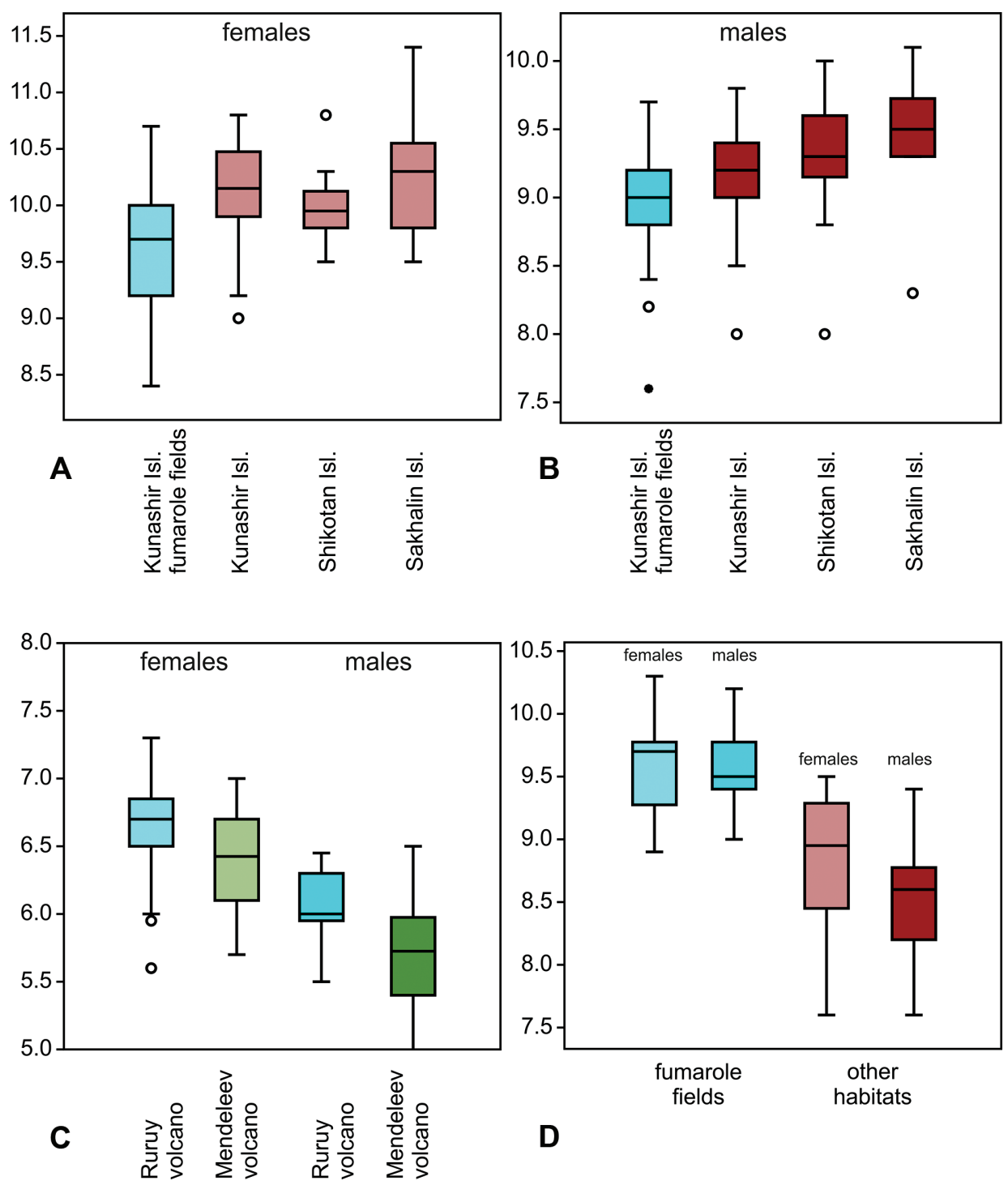

Fig. 9. Variability of sizes (EL) ground beetles inhabiting the fumarole fields: $A-B=$ Cicindela sachalinensis $(\mathrm{A}=$ females, $\mathrm{B}=$ males), $\mathrm{C}=$ Cylindera elisae; $\mathrm{D}=$ Poecilus samurai 


\section{CONCLUSIONS}

In most cases, the study of the influence of volcanic activity is limited to direct, often catastrophic effects on animals, including Coleoptera (see review by Elizalde 2014). Fumarola fields are one of the manifestations of volcanism under constant change. The micro-relief of the fumarola fields is formed or destroyed by thermal springs, mud pools and steam-gas emissions, also because hydrothermally altered rocks are subjected to denudation. According to lichen
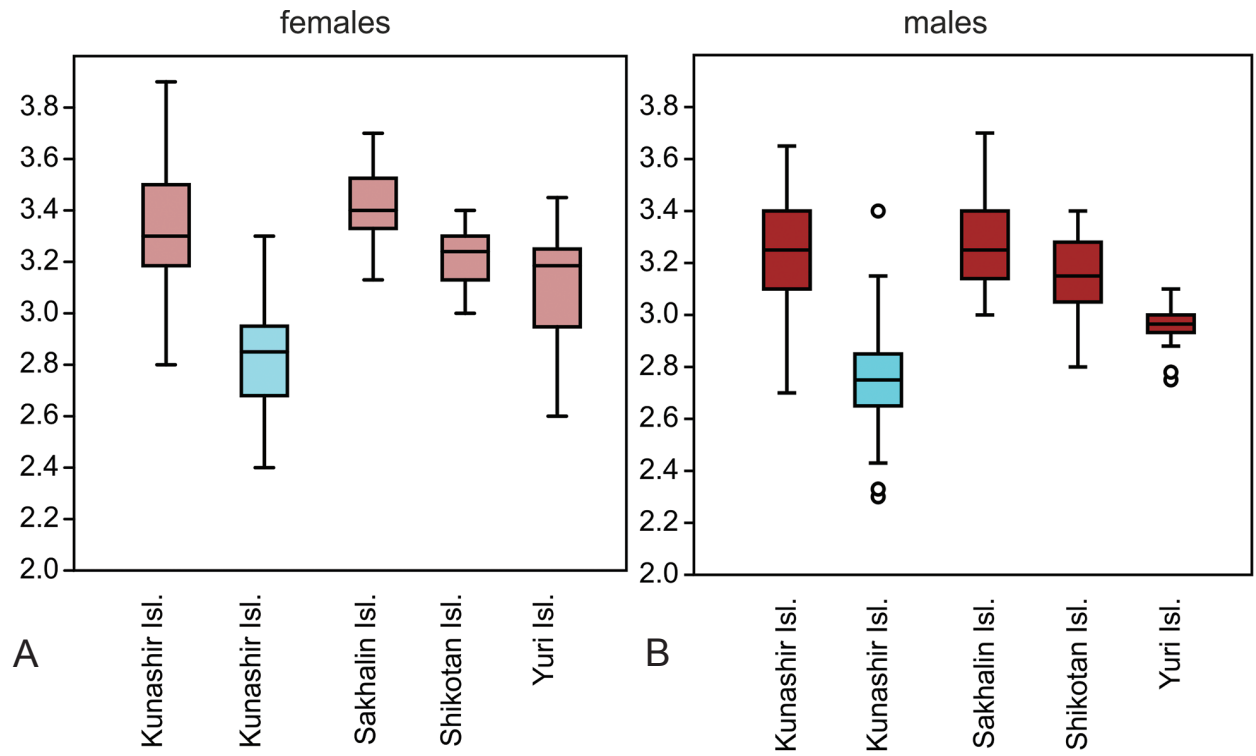

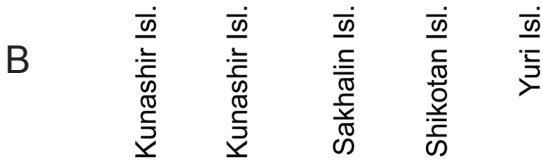
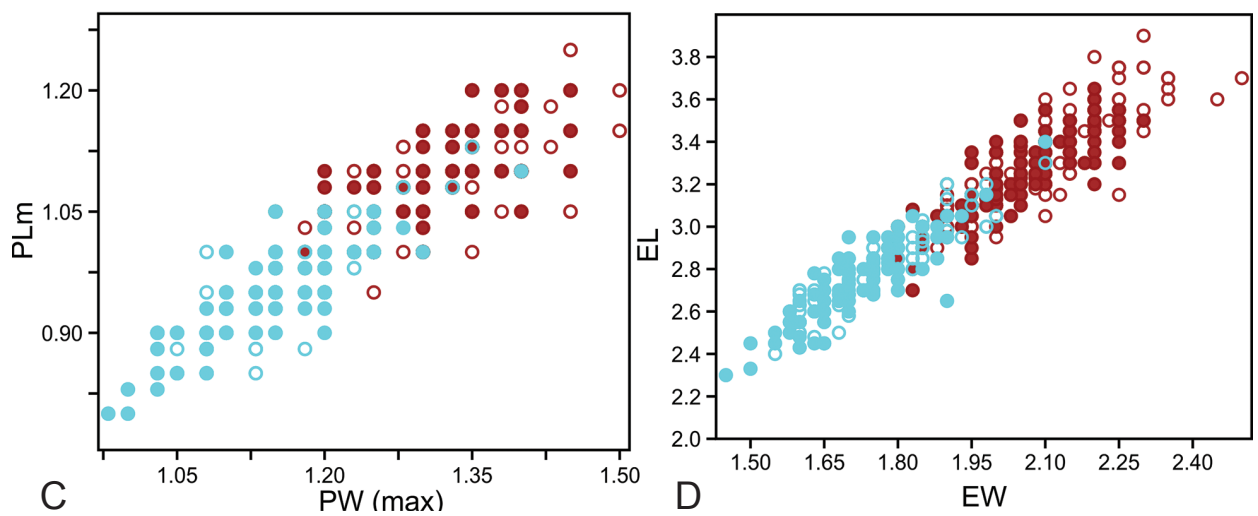

Fig. 10. Variation in size and proportion of Bembidion dolorosum: $A, B=$ length of elytra, $C=$ proportion of pronotum, $\mathrm{D}=$ proportion of elytra. Cyan = specimens from fumarole fields; brown $=$ specimens from common habitats 
bioindication data (EzHKIN 2019), fumarola fields have an influence 'halo' of ca. $600 \mathrm{~m}$ on Kunashir Island, but at distances of $>2 \mathrm{~km}$ such an effect is absent. The presence of such environmental gradients creates the prerequisites for gradual development of the adaptations in different species during their occupation of fumarola fields. Thus, the species inhabiting the fumarolas could be considered as model objects for the study of microevolutionary processes.

On Kunashir Island, only a few species of ground beetles have been able to colonize such fumarole fields. It is hardly surprising that the inhabitants of open spaces or the rocky banks of streams have become successful colonists. However, only $C$. sachalinensis and B. dolorosum were recorded from all volcanoes studied (Appendices: Figs A13, A14), while the remaining few species were narrowly localized. Cylindera elisae was found only on the Mendeleev and Ruruy volcanoes (Appendices: Fig. A12), B. sanatum only on the Mendeleev Volcano (Appendices: Fig. A15), while P. samurai, widespread across the island (Appendices: Fig. A16), only on the fumaroles of the Dokuchaev Mountain Ridge. Obviously, this unevenness and patchiness could have hardly been caused by environmental conditions, which were generally similar in all fumarole fields studied, and requires additional explanation.

The reaction of carabids to the special conditions of fumarole fields was species-specific. On the one hand, fumarola-inhabiting specimens of $C$. sachalinensis slightly differed from those in other habitats (Figs 8A, 9A, B); likewise, $B$. sanatum from the Kunashir, hardly differed from specimens from Honshu. On the other hand, specimens of $P$. samurai populating the fumarole fields differed noticeably in size and melanization (Figs 8B, 9D; Appendices: Figs A96-A97 vs. A98-A99), while C. elisae kunashirensis, in addition to the smaller size (Fig. 9C) and melanization (Fig. 1A), showed a relatively narrow labrum and was noticeably separated genetically (Fig. 2). The most interesting pattern of variability in all studied fumarole fields is demonstrated by B. dolorosum: as both temperature and acidity increase, specimens of this species become relatively small, elongated, and partially depigmented.

These differences could be associated both with certain features of different species and with the time of their adaptations to the conditions of fumarola fields. According to the data obtained, morphological changes do not depend on the taxonomic similarity of a species. Thus, $B$. dolorosum was extremely variable, while $B$. sanatum showed almost no particular change on the fumarola fields. Similar differences can also be seen between C. sachalinensis and C. elisae.

It is more difficult to assess the influence of time in the adaptation process. We can reasonably assume that widespread, flying species found in high numbers near the borders of fumarole fields (C. sachalinensis, B. dolorosum) have constantly inhabited these particular habitats. Specimens taken within or beyond fumarola fields were not distinguishable by their barcodes. Yet, 
they showed differences in morphological adaptations. Cicindela sachalinensis changed only slightly, while $B$. dolorosum, under increasing temperatures and acidity, was capable of developing forms that could erroneously be determined as different species.

The denuded landscapes of the fumarole fields and the headwaters of the streams on the Mendeleev Volcano, the single place where both Kunashir endemic carabids, C. elisae kunashirensis and B. sanatum, have been found, are formed at the site of explosion craters about 2,100-1,500 уВP (АвDURAKHMANOv et al. 2004). It is evident that such landscapes could have existed on the cone of Mendeleev Volcano earlier. The oldest volcanic layers not covered by marine sediments date back to about 39,000 yBP (LeBedev et al. 1980). We believe that the conditions of thermal (including fumarole) fields could have ensured the survival of some species under the colder conditions during the Pleistocene and Holocene, as in Bembidion ruruy Makarov et Sundukov, 2014 and several rove beetles (Shavrin \& Makarov 2019). Therefore, we believe that $C$. elisae kunashirensis might have colonized the Kunashir Island much earlier, and the time of its isolation could probably be associated with the Last Glacial Maximum, ca. 20,000 yBP (CLARK et al. 2009).

Earlier DNA studies support our hypothesis. Based on the sequences of the 28S rDNA and COI genes (Soт et al. 2011), C. elisae from various localities in Korea, Japan and Taiwan shows minimal divergence, especially in the COI sequences. At all localities studied, only one haplotype is widely distributed, the one that seems to have given rise to the remaining 17 haplotypes. Thereby most of those numerous haplotypes are separated from the basal one by no more than one to three mutational steps. Only the Taiwanese C. e. reductelinea$t a$ is distinct from the basal haplotype by 18-26 mutational steps (SотA et al. 2011: fig. 5A). The divergence time of this subspecies is ca. $0.6 \mathrm{Mya}$, this being comparable with the divergence time of ca .0.9 Mya for the more strongly related Cylindera bonina (Nakane et Kurosawa, 1959) which is endemic to the Bonin Islands (SотA et al. 2011: Fig. 4). According to these data, most of the insular and mainland subspecies of C. elisae (at least C. e. koreanica, C. e. novitia, C. e. mikurana and C. e. formosana) could be considered varieties. The presence of two subspecies of $C$. elisae on the Kunashir Island is not unique, because two subspecies of this species co-occur also in Taiwan. According to Sота et al. (2011), C. e. reductelineata could have populated Taiwan much earlier than C.e. formosana did. Based on the results of DNA analyses performed by us and considering the results by SотA et al. (2011), we can assume that $C$. e. kunashirensis could have colonized the Kunashir Island much earlier than the nominative subspecies. In our opinion, the evolution under the particular conditions of fumarola fields and the long-term isolation might have caused a significant genetic divergence of this subspecies. 
Estimating the divergence time of $B$. sanatum is more difficult because the species, both morphologically and genetically, is very close to the European B. stephensii, due to possible convergence (Netolitzky 1943: 37). Such patterns/disjunctions (amphi-Palaearctic or Euro-Manchurian) are also found among plants (Nakamura 2008, Denk \& Grimm 2009 etc.), vertebrates and various insect orders, such as Lepidoptera (Dubatolov \& Kosterin 2000), Odonatoptera (Kosterin 2002), Diptera (Oosterbroek et al. 2001), and Coleoptera (Semenov-Tian-Shansky 1911). Usually, the time of the origin of such disjunctions is attributed to the Pliocene or Miocene (MiккоLa 1987, NAKAMURA 2008). However, is likely that the later, repeated periods of warming allowed repeated recolonisation of former distribution areas, and that an estimate of 110,000-100,000 yBP is more realistic (Belova 1985, Dubatolov \& Kosterin 2000, Kosterin 2002). Thus, we can assume that the ancestors of $B$. sanatum could have entered this region no later than 100,000 yBP, and the isolation of the B. sanatum was associated with the Last Glacial Maximum under the conditioning influence of fumarola fields.

Although the isolation of the endemic forms of C. elisae and B. sanatum on the Mendeleev Volcano might have occurred at about the same time, the level of genetic divergence differs by an order of magnitude. The variance in the COI sequence of C. elisae elisae and C. elisae kunashirensis amounts to 206 mutation steps, while the same parameter for B. sanatum and B. stephensii is only 66 .

We conclude that the degree of the divergence of ground beetles, both morphological and genetic, during the adaptation to the specific conditions of fumarole fields varies very considerably and does not depend on taxonomic similarity or the time of colonization of fumarolas. This forces us to be careful in generalizations such as "the level of morphological (genetic) differences is enough to distinguish a species or subspecies".

Taking the ground beetles living in the specific and extreme conditions of fumarola fields as examples, we can see that the combination of flexible and conservative traits is one of the important reasons for the exceptionally high biological diversity of this family

Acknowledgements - We sincerely thank the administration and staff of the Kuril'sky Nature Reserve for the support rendered during our work and the arrangement of everyday life during the field surveys. We thank L. A. Sundukova (Lazo, Russia) and D. N. Kochetkov (Arkhara, Russia) for collecting and providing the authors with their collections from the southern Kuril Islands, V. I. Gusarov (Oslo, Norway) for the guidance on analytical procedures, I. A. Belousov (Saint-Petersburg, Russia) for comments on earlier drafts of the manuscript, A. A. Gusakov (Moscow, Russia) and B. M. Kataev (Saint-Petersburg, Russia) who kindly loaned the necessary type specimens for our study, David R. Maddison (Corvallis, USA) for the information on the DNA sequences of Bembidion sanatum and his 
helpful comments, Sergei Golovatch (Moscow, Russia) for checking the English, and to anonymous referees for their comments. Molecular lab work at the Natural History Museum, University of Oslo, was supported by the Norwegian Agency for International Cooperation and Quality Enhancement in Higher Education (Diku) (grant CPRU-2017/10072).

\section{REFERENCES}

Abdurakhmanov, A. I., Razjigaeva, N. G., Rybin, A. V., Gurianov, V. B. \& Zharkov, R. V. (2004): Vulkan Mendeleyeva - istoriya i sovremennoe sostoyanie (o. Kunashir, Kurilskie ostrova). Pp. 45-47. In: Gordeyev, E. I. (ed.): Vzaimosvyas' mezhdu tektonikoy, seysmichnost'yu, magmoobrazovaniyem i izverzheniyami vulkanov v vulkanicheskikh dugakh. Materialy IV Mezhdunarodnogo sovetshaniya po protsessam v zonakh subduktsii Yaponskoy, Kurilo-Kamchatskoy i Aleutskoy ostrovnykh dug. - Institut vulkanologii i seysmologii DVO RAN, Petropavlovsk-Kamchatskiy. [In Russian]

Bandelt, H., Forster, P. \& RöHL, A. (1999): Median-joining networks for inferring intraspecific phylogenies. - Molecular Biology and Evolution 16(1): 37-48. https://doi. org/10.1093/oxfordjournals.molbev.a026036

Bates, H. W. (1883): Supplement to the geodephagous Coleoptera of Japan, chiefly from the collection of Mr. George Lewis, made during his second visit, from February, 1880, to September, 1881. - The Transactions of the Entomological Society of London 1883: 205-290, pl. xiii. https://doi.org/10.1111/j.1365-2311.1883.tb02947.x

Belousov, I. A. \& Sокоlov, I. M. (1996): Review of the Caucasian species of the subgenus Peryphanes Jeannel (Coleoptera: Carabidae: Bembidion). - Stuttgarter Beiträge zur Naturkunde (Serie A: Biologie) 549: 1-40.

Belova, V. A. (1985): Vegetation and climate of the Late Cenozoic of the south of Eastern Siberia. - Nauka, Novosibirsk, 160 pp. [In Russian]

Clark, P. U., Dyke, A. S., Shakun, J. D., Carlson, A. E., Clark, J., Wohlfarth, B., Mitrovica, J. X., Hostetler, S. W. \& McCabe, A. M. (2009): The Last Glacial Maximum. Science 325: 710-714. https://doi.org/10.1126/science.1172873

Denk, T. \& Grimm, G. W. (2009): The biogeographic history of beech trees. - Review of Palaeobotany and Palynology 158(1): 83-100. https://doi.org/10.1016/j.revpalbo.2009.08.007

Dubatolov, V. V. \& Kosterin, O. E. (2000): Nemoral species of Lepidoptera (Insecta) in Siberia: a novel view on their history and the timing of their disjunctions. - Entomologica Fennica 11: 141-166. https://doi.org/10.33338/ef.84061

ElizALDE, L. (2014): Volcanism and arthropods: a review. - Ecología Austral 24: 3-16. https:// doi.org/10.25260/EA.14.24.1.0.32

Elven, H., Bachmann, L. \& Gusarov, V. I. (2010): Phylogeny of the tribe Athetini (Coleoptera, Staphylinidae) inferred from mitochondrial and nuclear sequence data. -Molecular Phylogenetics and Evolution 57: 84-100. https://doi.org/10.1016/j.ympev.2010.05.023

EzHKIN, A. K. (2019): Lichens of woody substrates in areas of solfataric activity in the southern Kuriles. - Geosistemy perekhodnykh zon 3(2): 256-263. https://doi.org/10.30730/25418912.2019.3.2.256-263 [In Russian]

Fedorchenko, V. I., Abdurakhmanov, A. I. \& Rodionova, R. I. (1989): Volcanism of the Kuril island-arc system. - Nauka, Moscow, 239 pp. [In Russian]

Folmer, O., Black, M., Hoen, W., Lutz, R. \& Vrijenhoek, R. (1994): DNA primers for amplification of mitochondrial cytochrome c oxidase subunit I from diverse metazoan invertebrates. - Molecular Marine Biology and Biotechnology 3: 294-299. 
Habu, A. (1967): Carabidae Truncatipennes group (Insecta: Coleoptera). Fauna Japonica. - Biogeographical Society of Japan, Tokyo, xiv + 338 pp., 27 pls.

Habu, A. (1973): A new Bembidion species from the Gotô Islands, Japan (Coleoptera, Carabidae). - The Entomological Review of Japan 25: 9-10.

Habu, A. \& UÉno, S.-I. (1955): A new subgenus and a new species of the tribe Bembidiini. (The Carabidae-fauna of Mt. Hiko, III). - Mushi 28: 43-47.

Hammer, O., Harper, D. A. T. \& Ryan, P. D. (2001): PAST: Paleontological statistics software package for education and data analysis. - Palaeontologia Electronica 4(1): 1-9.

InOuYe, H. (1971): The carabid-beetles from Shiretoko Peninsula, Hokkaido, Japan (I). - The Entomological Review of Japan 23(1): 39-44.

JEDLIČKA, A. (1933): Bestimmungstabelle der mir bekannten Bembidion-Arten aus China. Časopis Československé Společnosti Entomologické 30: 56-64, 97-103.

JedličKA, A. (1965): Monographie des Tribus Bembidiini aus Ostasien (Coleoptera, Carabidae). - Entomologische Abhandlungen und Berichte aus dem Staatlichen Museum für Tierkunde in Dresden 32[1964-1967]: 79-199.

Кімото, S. \& Yasuda, N. (1995): The ground beetles of Hokkaido. Ecological and biological survey. - Tokai University Press, Tokyo, 315 pp. [In Japanese]

Kimura, M. (1980): A simple method for estimating evolutionary rates of base substitutions through comparative studies of nucleotide sequences. - Journal of Molecular Evolution 16: 111-120. https://doi.org/10.1007/BF01731581

Kirschenhofer, E. (1984): Neue paläarktische Bembidiinae unter besonderer Berücksichtigung der von Eigin Suenson in Ostasien durchgeführten Aufsammlungen. 1. Teil, Bembidion Latreille. - Koleopterologische Rundschau 57: 57-92.

Konakov, N. N. (1956): Fumarole fauna of the southern Kurile volcanoes. - Trudy AN SSSR. Seria zoologicheskaya 3(6): 163-172. [In Russian]

Kosterin, O. E. (2002): Western range limits and isolates of eastern odonate species in Siberia and their putative origins. - Odonatologica 34(3): 219-242.

Kryvolutskaja, G. O. (1973): Entomofauna of the Kuril Islands. Principal features and origins. - Nauka, Leningrad, 316 pp. [In Russian]

KryzhanovskiJ, O. L. (1968): New or poorly-known ground beetles (Coleoptera, Carabidae) of the fauna of the USSR and adjacent countries. - Entomologicheskoe Obozrenie 47: 160-175. [In Russian]

Kryzhanovskij, O. L., Belousov, I. A., Kabak, I. I., Kataev, B. M., Makarov, K. V. \& ShileNкоv, V. G. (1995): A checklist of the ground-beetles of Russia and adjacent lands (Insecta, Coleoptera, Carabidae). - Pensoft Publishers, Sofia-Moskow, 271 pp.

Kryzhanovskij, O. L., Окнотіna, M. V., Bromlei, G. F. \& Lafer, G. Sh. (1975): A review of the ground-beetles (Coleoptera, Carabidae) of the Kuril Islands. - Entomologicheskie issledovaniya na Dalnem Vostoke. Trudy Biologo-pochvennogo instituta DVO AN SSSR 28(3): 119-142. [In Russian]

Kumar, S., Stecher, G., Li, M., Knyaz, C. \& Tamura, K. (2018): MEGA X: Molecular evolutionary genetics analysis across computing platforms. - Molecular Biology and Evolution 35: 1547-1549. https://doi.org/10.1093/molbev/msy096

Kuwayama, S. (1967): Insect fauna of the southern Kurile Islands. - Sapporo, 225 pp.

LAfer, G. SH. (1978): Review of the tiger beetles (Coleoptera, Carabidae) of Far East of the USSR. Pp. 3-18. In: Ivliev, L. A., Paschenko, N. F. \& Simakova, T. P. (eds): Biology of some useful and harmful insects of the Far East. - Dalnauka, Vladivostok. [In Russian]

Lafer, G. Sh. (1989): 4. Family Carabidae - The ground-beetles. Pp. 71-222. In: Lehr, P. A. (ed.): Opredelitel' nasekomykh Dal'nego Vostoka SSSR. T. 3. Zhestkokrylye, ili zhuki. Part 1. - Nauka, Leningrad. [In Russian] 
Lafer, G. Sh. (1992): 4. Family Carabidae - The ground-beetles. 42. Agonum Bon. Pp. 602621. In: Lehr, P. A. (ed.): Opredelitel' nasekomykh Dal'nego Vostoka SSSR. T. 3. Zhestkokrylye, ili zhuki. Part 2. - Nauka, St. Petersburg. [In Russian]

LAFER, G. SH. (1998): Supplementary accounts of the ground-beetle fauna (Coleoptera, Carabidae) of the Southern Kuril Islands. - Far East Entomologist 59: 19-20.

LAfER, G. SH. (1999): Contributions to the knowledge of Coleoptera fauna (Insecta) of Kunashir, Kuril Islands. - Far Eastern Entomologists 77: 1-16.

LAFER, G. SH. (2002a): Ground beetles (Coleoptera, Caraboidea) of southern oceanic islands of the Great Kuril Ridge. - Euroasian Entomological Journal 1(1): 47-66. [In Russian]

LAfer, G. SH. (2002b): A new species of the genus Bembidion Latreille (Coleoptera, Carabidae) from Kunashir, southern Kuril Islands. - Baltic Journal of Coleopterology 2(1): 45-48.

LAfER, G. SH. (2006): Ground-beetles (Coleoptera: Cicindelidae, Carabidae) of Moneron Island. Pp. 218-227. In: Storozhenko, S. Yu. (ed.): Flora and fauna of Moneron Island. Materials of the International Sakhalin Island Project. - Dalnauka, Vladivostok. [In Russian]

Lebedev, L. M., Shurmanov, L. P. \& Nikitina, I. B. (1977): New data on the mineralogy of a sulfide lode on the northeastern slope of Mendeleev Volcano. Pp. 104-122. In: LebeDEv, L. M. (ed.): Modern hydrothermal vents and mineral formation. - Nauka, Moscow. [In Russian]

Lebedev, L. M., Zotov, A. V., Nikitina, I. B., Dunichev, V. M. \& Shurmanov, L. P. (1980): Sovremennye protsessy mineraloobrasovaniya na vulkane Mendeleyeva (o-v Kunashir). Nauka, Moscow, 176 pp. [In Russian]

Leigh, J. W. \& BRyant, D. (2015): PopART: Full-feature software for haplotype network construction. - Methods in Ecology and Evolution 6(9): 1110-1116. https://doi. org/10.1111/2041-210X.12410

Makarov, K. V., Kryzhanovskij, O. L., Belousov, I. A., Zamotailov, A. S., KabaK, I. I., Kataev, B. M., Shilenkov, V. G., Matalin, A. V., Fedorenko, D. N. \& Komarov, E. V. (2020): Taxonomical list of ground beetles (Carabidae) of Russia. Last updated: May 25, 2020 https://www.zin.ru/animalia/coleoptera/rus/car_rus.htm [In Russian]

Makarov, K. V., Melnik, I. V. \& Matalin, A. V. (2013): Concrete and local faunas of the Coleoptera of Kunashir. Pp. 54-56. In: Zamotajlov, A. S. \& Shapovalov, M. I. (eds): Biodiversity. Bioconservation. Biomonitoring. - Adyghei State University, Maikop. [In Russian]

Makarov, K. V. \& Sundukov, Yu. N. (2011): First records of Euplynes batesi and Agonum lampros (Coleoptera: Carabidae, Platynini) from Russia. - Far Eastern Entomologist 234: 34-36.

Makarov, K. V. \& Sundukov, Yu. N. (2014): Bembidion (?Nipponobembidion) ruruy sp. n., a new brachypterous ground beetle (Coleoptera, Carabidae) from Kunashir Island, Kuriles, Russia. - ZooKeys 463: 75-93. https://doi.org/10.3897/zookeys.463.8504

Makarov, K. V. \& Sundukov, Yu. N. (2016): Distribution and biology of the ground beetle Carabus (Damaster) blaptoides rugipennis (Motschulsky, 1861) on Kunashir Island, Kurile Islands, Russia. - Nature Conservation Research 1(3): 7-15. https://doi. org/10.24189/ncr.2016.026

Makarov, K. V., Sundukov, Yu. N. \& Korepanov, M. K. (2019a): A review of the genus Odacantha (Coleoptera, Carabidae) of the Russian Far East. - Far Eastern Entomologist 380: 8-19. https://doi.org/10.25221/fee.380.2

Makarov, K. V., Sundukov, Yu. N. \& Matalin, A. V. (2019b): Ground beetles (Coleoptera, Carabidae) of Kunashir Island's fumarole fields, Kuril Archipelago. - ARPHA Conference Abstracts 2: e38521, P. 1-3 (XIX ECM). https://doi.org/10.3897/aca.2.e38521 
Marggi, W., Toledano, L. \& Neri, P. (2017): Subtribe Bembidiina Stephens, 1827. Pp. 294-342. In: LöвL, I. \& LöвL, D. (eds): Catalogue of Palaearctic Coleoptera. Volume 1. Archostemata - Myxophaga - Adephaga. Revised and Updated Edition. Volume 1. Brill, Leiden-Boston.

Miккоца, K. (1987): Pattern of noctuid species common between the extremities of the Palaeacrtic zone: a result of glacial and postglacial movements. - Tinea 12(Suppl.): 310-315.

Mori, M. (2016): Mizugiva scavenger beetles in Hyogo Prefecture. - Kiberi Ha Mushi 39(1): 26-35. [In Japanese]

Morita, S. (2010): Notes on the Bembidiinae (Coleoptera, Carabidae) of Japan XXIII. Bembidion (Ocydromus) negrei Habu and its new relatives, found in the habitats of hot springs. - Elytra 16(1): 13-21.

NAKAmura, Y. (2008): Biogeographical study of Japanese beech forests under different climatic conditions. - Berichte der Reinhold-Tüxen-Gesellschaft 20: 179-194.

Nakane, T. (1963): A list of Coleoptera from the Shiretoko Peninsula, Hokkaido, Japan (Insecta). - The Scientific Reports of the Kyoto Prefectural University (A: Nat. Sci.) 3(5): 237-245.

Nakane, T. (1979): New or little-known Coleoptera from Japan and its adjacent regions, XXX. - Reports of the Faculty of Science of Kagoshima University (Earth Sciences E Biology) 12: 51-60.

Nakane, T. \& Kurosawa, Y. (1959): A new species of the genus Cicindela from Bonin islands. - Bulletin of the National Science Museum 4: 372-373.

Neri, P. \& Vigna Taglianti, A. (2010): Note su Ocydromus alticola e O. incognitus, con descrizione di una nuova razza di O. alticola dei Monti della Laga, Appennino Centrale (Coleoptera, Carabidae). - Bollettino della Società Entomologica Italiana 142: 111-120.

NetolitzKy, F. (1943): Bestimmungstabellen europäischer Käfer (9. Stück). II. Fam. Carabidae. Subfam. Bembidiinae. 66. Gattung: Bembidion Latr. Bestimmungstabelle der Bembidion-Arten des paläarktischen Gebietes. (Mit Hinweisen auf holarktische, äthiopische und orientalische Arten). - Koleopterologische Rundschau 29: 1-70.

Окоnеснnikov, K., Golosova, O., Fursov, M. \& the UGENE team. (2012): Unipro UGENE: a unified bioinformatics toolkit. - Bioinformatics 28(8): 1166-1167. https://doi. org/10.1093/bioinformatics/bts091

Oosterbroek, P., Dufour, C. \& Pilipenko, V. (2001): On the presence of Dolichopeza (subgenus Oropeza) in the West Palaearctic (Diptera, Tipulidae). - Bulletin de la Société Neuchâteloise des Sciences Naturelles 124: 119-123.

Puchkov, A. V. \& Matalin, A. V. (2003): Subfamily Cicindelinae Latreille, 1802. Pp. 99118. In: Löbl, I. \& Smetana, A. (eds): Catalogue of Palaearctic Coleoptera. Volume 1. Archostemata - Myxophaga - Adephaga. - Apollo Book, Stenstrup.

Puchkov, A. V. \& Matalin, A. V. (2017): Subfamily Cicindelinae Latreille, 1802. Pp. 217249. In: LöвL, I. \& LöвL, D. (eds): Catalogue of Palaearctic Coleoptera. Volume 1. Revised and Updated Edition. Archostemata - Myxophaga - Adephaga. Brill, Leiden-Boston. https://doi.org/10.1163/9789004330290

PütZ, A. \& Wiesner, J. (1994): Cylindera (Cicindina) elisae kunashirensis - eine neue subspezies von der Kurileninsel Kunashir (Col., Cicindelinae). - Entomologische Nachrichten und Berichte 38: 251-254.

Sabirov, R. N., Sabirova, N. D., Ktitorov, P. S., Sundukov, Yu. N., Savchenko, G. G., Ezhrin, A. K. \& Grishchenko, M. Yu. (2014): The Nature Monument "Mendeleev Volcano" on Kunashir Island. - Vestnik Sakhalinskogo muzeya 21: 290-318. [In Russian] 
Semenov-Tian-Shansky, A. (1911): Un représentant nouveau du genre Rosalia Serv. (Coleoptera, Cerambycidae) provenant du district d'Ussuri (Sibérie or.). - Revue Russe d'Entomologie 9(1): 118-123.

Shavrin, A. V. \& MaKarov, K. V. (2019): Contribution to the knowledge of the fauna of rove beetles of the subfamily Omaliinae MacLeay, 1825 (Coleoptera: Staphylinidae) of Kunashir Island, Kurile Islands. - Russian Entomological Journal 28(1): 36-53. https:// doi.org/10.15298/rusentj.28.1.06

Sota, T., Liang, H., Enokido, Y. \& Hori, M. (2011): Phylogeny and divergence time of island tiger beetles of the genus Cylindera in East Asia. - Biological Journal of the Linnean Society 102: 715-727. https://doi.org/10.1111/j.1095-8312.2011.01617.x

Sundukov, Yu. N. (2001): New data on the carabid fauna (Coleoptera, Carabidae) of the Russian Far East. - Entomological Review 81(6): 729-732.

Sundukov, Yu. N. (2008): Species of the subgenus Baudia of the genus Badister (Coleoptera, Carabidae) from the Southern Sikhote-Alin Mountains. - Entomological Review 88(8): 948-953. https://doi.org/10.1134/S0013873808080083

Sundukov, Yu. N. (2011): A review of the genus Cymindis Latreille, 1806 (Coleoptera, Carabidae, Lebiini) of East Asia. - Amurian Zoological Journal 3(4): 315-344. [In Russian]

Sundukov, Yu. N. (2017): The ground beetles (Coleoptera, Carabidae) of the Yuri Island, southern Kuriles. - A. I. Kurentsov's Annual Memorial Meetings 28: 101-110. [In Russian]

Sundukov, Yu. N. \& Makarov, K. V. (2013): The ground beetles (Coleoptera, Carabidae) of Shikotan Island, Kuril Islands, Russia. - Euroasian Entomological Journal 12(4): 339348. [In Russian]

Sundukov, Yu. N. \& Makarov, K. V. (2016): New or little-known ground beetles (Coleoptera: Carabidae) of Kunashir Island, Kurile Islands, Russia. - Russian Entomological Journal 25(2): 121-160. https://doi.org/10.15298/rusentj.25.2.01

Sundukov, Yu. N. \& Makarov, K. V. (2019): The Dokuchaev Mountain Ridge as the main faunal refugium of Kunashir Island. - A. I. Kurentsov's Annual Memorial Meetings 30: 63-79. [In Russian] https://doi.org/10.25221/kurentzov.30.5

Tamura, K., Battistuzzi, F. U., Billing-Ross, P., Murillo, O., Filipski, A. \& Kumar, S. (2012): Estimating divergence times in large molecular phylogenies. - Proceedings of the National Academy of Sciences 109: 19333-19338. https://oi.org/10.1073/ pnas.1213199109

Toledano, L. (2009): Notes on the Bembidiina of Taiwan with description of three new species (Coleoptera: Carabidae). - Acta Entomologica Musei Nationalis Pragae 49: 577-598.

Toledano, L. (2011): Notes on new and poorly known Chinese Bembidiina (Coleoptera: Carabidae). - Koleopterologische Rundschau 81: 5-19.

Watanabe, T. (1989): The Coleoptera of Miyagi Prefecture, Japan. - Japanese Society of Coleopterology, Tokyo, 365 pp. $+X$ pls.

Wiesner, J. (1992): Verzeichnis der Sandlaufkäfer der Welt. Checklist of the Tiger Beetles of the World (Coleoptera, Cicindelidae). - Erna Bauer Verlag, Keltern, 364 pp.

Wiesner, J., Bandinelli, A. \& Matalin, A. (2017): Notes on the tiger beetles (Coleoptera: Carabidae: Cicindelinae) of Vietnam. - Insecta Mundi 589: 1-131.

Yasui, M. \& Shiyake, Sh. (2008): Fauna and distribution of the bembidiine ground beetles (Coleoptera: Carabidae) in Yamatogawa River system, central Japan. - Bulletin of the Osaka Museum of Natural History 62: 27-45.

Yoshitake, H., Kurihara, T., Yoshimatsu, Sh., Nakatani, T. \& Yasuda, K. (2011): A list of carabid specimens (Insecta: Coleoptera) collected by the late Dr. Akinobu Habu 
preserved in the Insect Museum of the National Institute for Agro-Environmental Sciences. - Bulletin of National Institute for Agro-Invironmental Sciences 28: 1-327.

Yoshimatsu, S., Ito, N., Nakatani, Y. \& Yoshitake, H. (2018): A list of ground beetles (Insecta: Coleoptera: Caraboidea) in Dr. Kazuo Tanaka Collection preserved in the Insect Museum of Institute for Agro-Environmental Sciences, NARO. - Bulletin of the NARO, Agro-Environmental Sciences 39: 15-192. [In Japanese]

Received November 23, 2020, accepted December 7, 2020, published December 28, 2020

\section{Appendix 1. Detailed characteristics of the studied fumarola fields.}

\section{Ruruy Volcano}

Despite the high density and variety of volcanic edifices in the northern part of the Kunashir Island, two areas of thermal-solfatara activity: "Neskuchenskie springs" and "Dal'nie springs" are known only on the western seashore.

The "Neskuchenskie Springs" is stretched along the seacoast for ca. $1.2 \mathrm{~km}$ and covers an area of about $1.5 \mathrm{~km}^{2}$. The fumarola fields a total area ca. $3000 \mathrm{~m}^{2}$ (ZнаRкоv 2014). The "First Upper" solfatara field is located at an altitude of $70 \mathrm{~m}$ a.s.l. and covers an area of about $1700 \mathrm{~m}^{2}$. The solfatara activity is observed in its apical part, where the gas temperature reaches $100{ }^{\circ} \mathrm{C}$. The "Second Upper" solfatara field with an area of about $800 \mathrm{~m}^{2}$, is located slightly to the north. Its fumarola outcrops also have a temperature of $100.0-100.9^{\circ} \mathrm{C}$, and the waters of the streams flowing from there are subneutral $(\mathrm{pH}=6.9-7.3)$. The "Third Upper" solfatara field is located at an altitude of $210 \mathrm{~m}$ a.s.l. Its sulphate calcium-sodium waters are acidic $(\mathrm{pH}=2.2)$, with the temperatures of up to $91.7^{\circ} \mathrm{C}$. Besides, there are two "extinct" fumarola sites and numerous acidic hydrothermal and solitary fumarola outcrops.

The "Dal'nie Springs" site was discovered only in 2017 (SunduKov \& KozlovsKI 2017) and volcanologists have never studied it. The site with hydrothermal-solfataric activity was located in a bowl-shaped depression at an altitude of 390-560 m a.s.l. and covered an area of about $1 \mathrm{~km}^{2}$. It includes two solfatara fields, "Dlinnoe" and "Bolshoye". The "Bolshoye" field is $3500 \mathrm{~m}^{2}$ located at $390-400 \mathrm{~m}$ a.s.l. The "Dlinnoe" field is $100 \mathrm{~m}$ to the southwest and has an area of about $1500 \mathrm{~m}^{2}$. In both these fields, only a weak solfataric activity is presently observed. The gases escaping from the fumarolas have a temperature of $18.0-22.3^{\circ} \mathrm{C}$, the temperature of the streams flowing through the fields ranges from 20.4 ${ }^{\circ} \mathrm{C}$ to $22.5^{\circ} \mathrm{C}$, their water being weakly acidic $(\mathrm{pH}=4.0-4.2)$.

\section{Mendeleev Volcano}

The outputs of the solfatara gases are concentrated on the Mendeleev Volcano in four fields: southeastern, eastern, northeastern, and northwestern. In the valleys of the rivers and streams originating from these fields, there are groups of thermal springs with varying temperatures and chemical composition (Tables $1 \& 2$ ).

The southeastern field is $400-575 \mathrm{~m}$ a.s.l. and has an area of about $75,000 \mathrm{~m}^{2}$, with numerous outlets of small gas jets, as well as thermal and cold mineral springs in its upper part. Thermophilic algae grow in places where the thermal waters come out, and there is a strong odour of hydrogen sulfide. The water is acidic $(\mathrm{pH}=2.5)$, siliceous, sulphatechloride, with a complex cationic composition and a mineralization level of about $1 \mathrm{~g} / \mathrm{l}$ (MarkHinin \& Stratula 1977). 
The eastern field is stretched out in a narrow strip along the upper reaches of Lechebnyi Stream at $650-450 \mathrm{~m}$ a.s.l. It includes a small thermal lake $\left(\mathrm{T}=60-85^{\circ} \mathrm{C}, \mathrm{pH}=3.3\right)$ and numerous springs, mud griffins and funnels with the temperatures of $53-101^{\circ} \mathrm{C}$ and $\mathrm{pH}=2.7-3.6$. The thermal waters are sulphate calcium-magnesium with increased content of $\mathrm{Al}^{3+}, \mathrm{Fe}^{2+}, \mathrm{H}^{+}$and a mineralization level of about $1 \mathrm{~g} / \mathrm{l}$. According to the composition of gases, they are carbonic: $\mathrm{CO}_{2}-43.6 \%, \mathrm{~N}_{2}-39.1 \%, \mathrm{CH}_{4}-14.2 \%$, with no $\mathrm{H}_{2} \mathrm{~S}$ detected (MARKHININ \& Stratula 1977).

The northeastern field is the most active area. In 1880, a weak phreatic eruption occurred there (Milne 1896), and in 1901, 1946, 1977 and 1987 emissions of the steam-gas jets up to a height of 150-200 $\mathrm{m}$ and tangible earthquakes were observed. This fumarola field is at $250-350 \mathrm{~m}$ a.s.l. and an area ca. $2 \mathrm{~km}^{2}$. There are three eroded funnels of phreatic explosions, which are the centres of discharging acid sulphate-chloride fluids (LeBEDEv et al. 1977). There are numerous fumarolas with the temperatures of up to $99.6^{\circ} \mathrm{C}$, and in the valley of Kislaya River, flowing from this field, there are dozens of springs with the temperatures of $90.0-98.5^{\circ} \mathrm{C}$ and $\mathrm{pH}=2.4-2.5$. The waters of these springs are acidic, carbonic $\left(\mathrm{CO}_{2}\right.$ - about $89 \%, \mathrm{H}_{2} \mathrm{~S}-$ up to $\left.4.7 \%, \mathrm{O}_{2}-0.5 \%\right)$ sulphate sodium-calcium-magnesium hydrothermal fluids (MARKHININ \& STRATUla 1977).

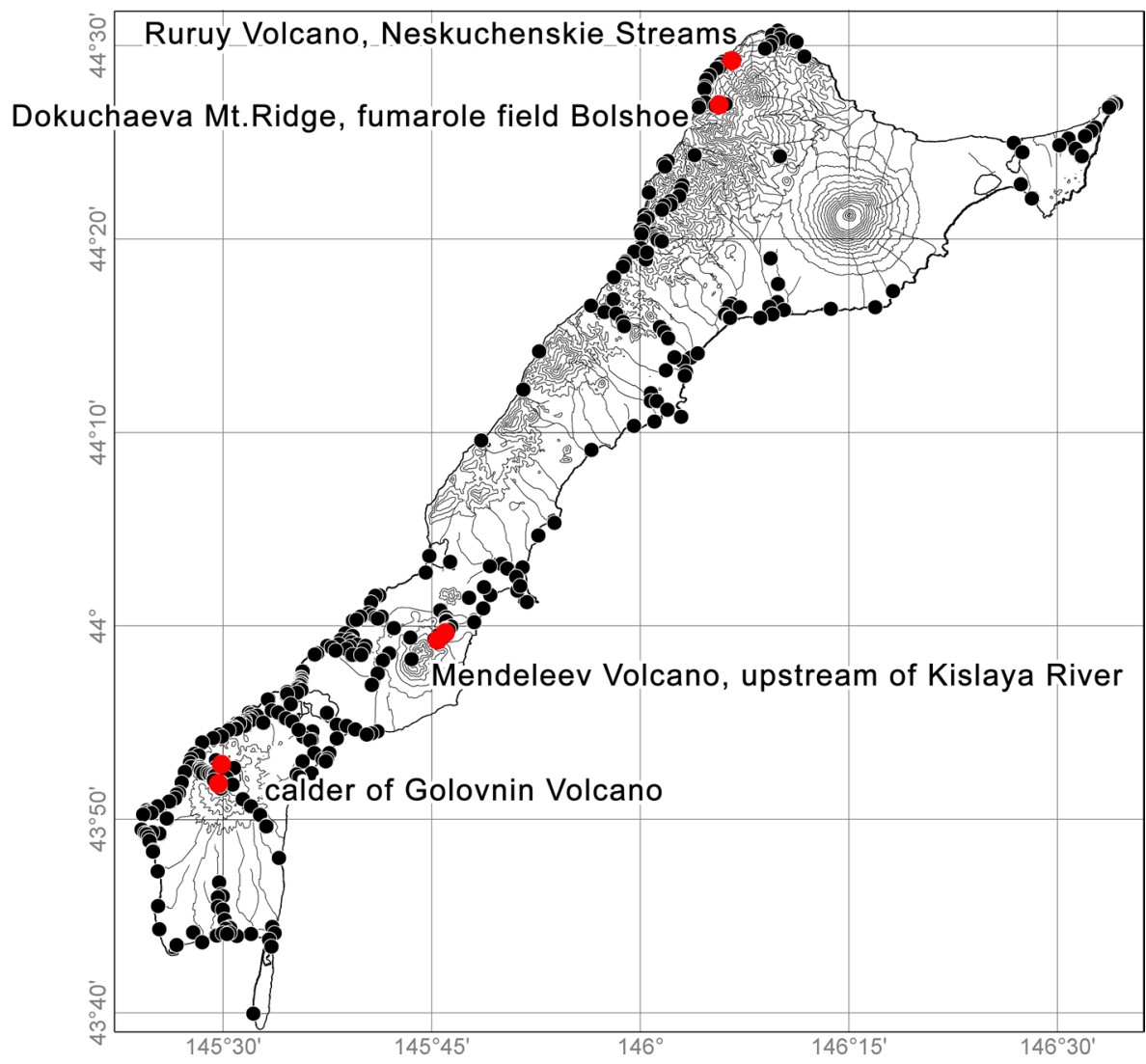

Fig. A1. Locations of the collection sites (black points) and the studied solfatar fields (red points) on the Kunashir Island 
The northwest field is at a $400 \mathrm{~m}$ a.s.l. and is about $50,000 \mathrm{~m}^{2}$ in area. Its solfataric activity is relatively high: in 1978 and 1984, the temperature increased to $111-113{ }^{\circ} \mathrm{C}$, accompanied by the appearance of molten sulfur (ZнаRкоv 2014). This field also supports a "boiling" spring with a temperature of $>90^{\circ} \mathrm{C}$. Its water is highly acidic $(\mathrm{pH}=2.5-3.0)$, sulphate-chloridic, with a total mineralization level of up to $4.4 \mathrm{~g} / \mathrm{l}$. Carbon dioxide and hydrogen sulphide $\left(\mathrm{CO}_{2}-88.1 \%, \mathrm{H}_{2} \mathrm{~S}-9.8 \%, \mathrm{~N}_{2}-2.1 \%\right.$, the $\mathrm{CH}_{4}$ content being negligible) prevail in the gas composition (MARKHININ \& StRATUla 1977).

\section{Golovnin Volcano}

A large eruption that formed the modern caldera about $4.7 \mathrm{~km}$ in diameter, according to various estimates, occurred about 52,000-30,000 yBP (MeleKestsev et al. 1988, Bulgakov 1994). At present, the caldera contains five terrestrial and one underwater fumarola fields and two lakes, with thermal waters. Its chemical composition is given in Tables 1 and 2.

The Central Eastern solfatara field is located at the foot of the southern slope of the Central Eastern dome. All gas outlets and thermal springs are situated along the shores or under the water of Lake Kipyashcheye. Both solfataras $\left(\mathrm{T}=90-100^{\circ} \mathrm{C}\right)$, as well as the boiling cauldrons of various sizes, consistencies and colors $\left(\mathrm{T}=60-95^{\circ} \mathrm{C}\right)$, are located there. Their waters range from subneutral hydrocarbonate-sulphate sodium-calcium $(\mathrm{pH}=6.0$ 8.5) to acidic sodium sulphate ( $\mathrm{pH}=2.0-2.5)$ (Zнаккоv 2014).

Lake Kipyashcheye is a phreatic explosion funnel filled with water, with an area of $66,000 \mathrm{~m}^{2}$ and a depth of $16 \mathrm{~m}$ (Kozlov \& Zharkov 2010). Its acidic (pH = 2.5), chloridesulphate sodium waters are heated up to $90^{\circ} \mathrm{C}$ in the places where gas-hydrothermal vents emerge. In the central part of the lake, the chemical composition of the water is predominantly sodium chloride, $\mathrm{pH}=3.7$, and the surface temperature is about $30^{\circ} \mathrm{C}$ (MARKHININ \& Stratula 1977).

Lake Goryacheye occupies the northern part of the caldera with a $3.1 \mathrm{~km}^{2}$ area, 62.3 $\mathrm{m}$ maximum depth, and a surface water temperature of $17-18^{\circ} \mathrm{C}$. The water is acidic $(\mathrm{pH}=$ 2.5-3.0) and contains sulphate-chloride sodium-calcium (Zотоv et al. 1988). There are four fumarola fields at the lake shores.

The Central Western solfatara field is at the southern shore of the lake. Its formation seems to have been associated with a phreatic eruption on the northern slope of the Central West extrusive dome. The solfataras and thermal boilers are the hottest ones on the volcano - from $90{ }^{\circ} \mathrm{C}$ to $102.5^{\circ} \mathrm{C}$ (Zнаккоv 2014). In terms of gas composition, they are similar to the solfatars of the Central Eastern field, but carbon dioxide and hydrogen sulphide are contained in equal proportions ( $48 \%$ each), and the condensate of the gases has a sulphate calcium chemical composition and $\mathrm{pH}=2.8$ (MARKHININ \& STRATUla 1977). The lower part of this field shows a temperature of $98^{\circ} \mathrm{C}$ and has highly acidic $(\mathrm{pH}=2.0)$, sulphate-chloride calcium-sodium waters.

At the northern bank of Lake Goryacheye, three small solfatara fields are located: Cherepakhovoye, Nabokovskoye, and Bezymyannoye. The solfatars and hydrosulfatars of the Cherepakhovoye field are quite intense. The temperature of the solfataras reaches $98{ }^{\circ} \mathrm{C}$, while the temperature of the springs is $80{ }^{\circ} \mathrm{C}$; the solfataras are carbonic $\left(\mathrm{CO}_{2}-94 \%\right)$ with acidic spring $(\mathrm{pH}=2.3)$, while sulphate calcium-sodium with medium mineralized, waters (Markhinin \& Stratula 1977). The Nabokovskoye field has four low-rate extinct sources with a temperature of $38-52{ }^{\circ} \mathrm{C}$ and $\mathrm{pH}=6.0$ (Zнаккоv 2014). Within the Bezymyannoye field, the solfataras are concentrated to two areas: at and a few dozen meters off the bank of 
Lake Goryacheye. This field is characterised by the development of mud pots with temperatures up to $89^{\circ} \mathrm{C}$ and $\mathrm{pH}=3.4$. In the channel of the stream and the upland areas, there are

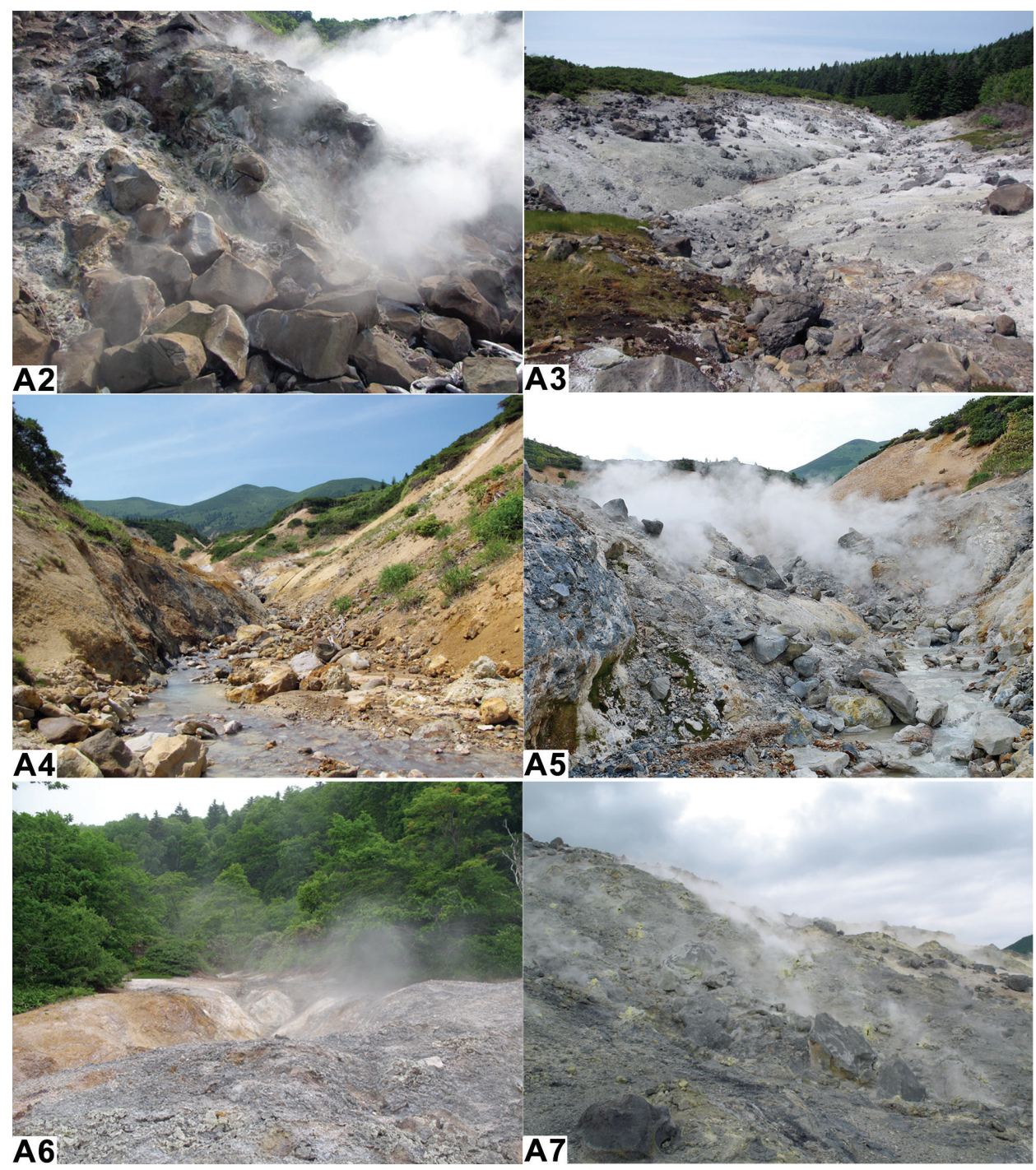

Figs A2-A7. Habitats of ground beetles in the solfatar fields of Kunashir Isl.: A2 = Ruruy Volcano, Neskuchenskie Streams (C. elisae elisae, B. dolorosum); A3 = Dokuchaeva Mt. Ridge, solfatara field "Bolshoye" (C. sachalinensis, P. samurai); A4 = Mendeleev Volcano, upstream of Kislyi Stream (C. sachalinensis, B. dolorosum, B. sanatum); A5 = Mendeleev Volcano, Northeastern solfatara field (C. elisae kunashirensis); A6 = caldera of Golovnin Volcano, solfatara field "Cherepakhovoye" (B. dolorosum); A7 = caldera of Golovnin Volcano, Central West solfatara field (C. sachalinensis) 


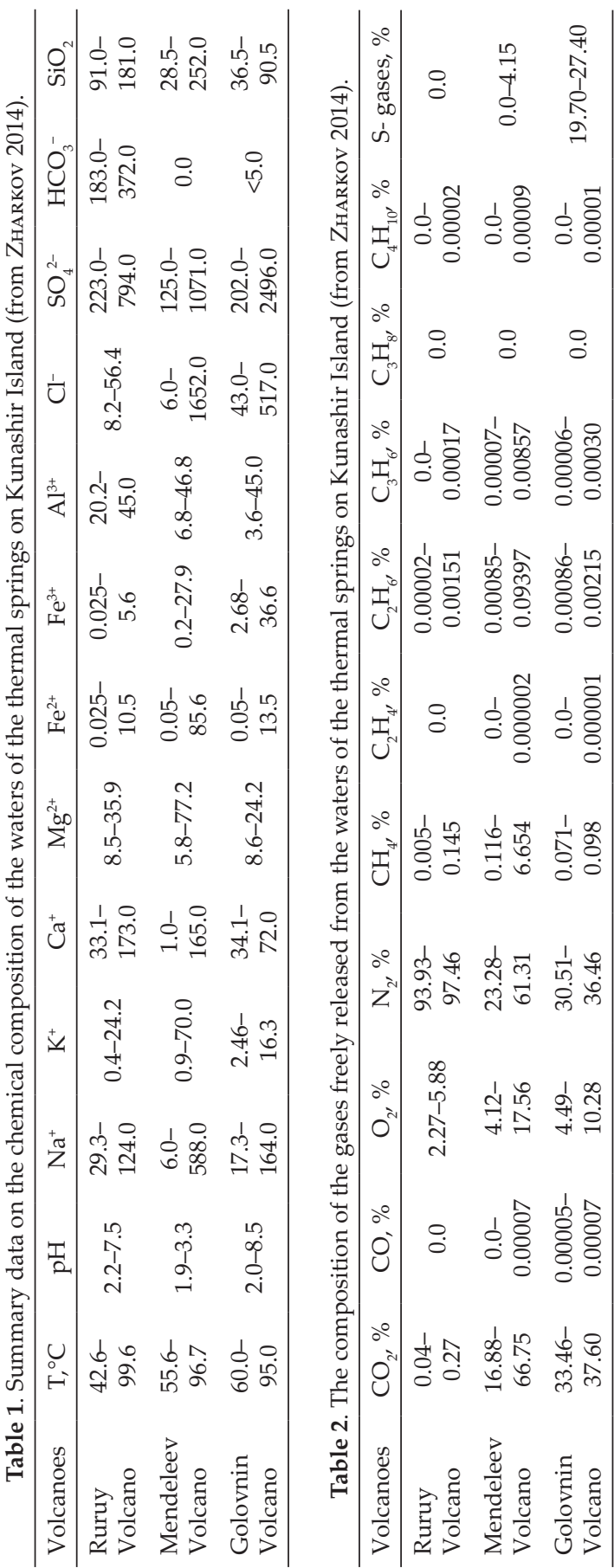

numerous outlets of gases with a temperature of $100-101{ }^{\circ} \mathrm{C}$ (ZHARKOV 2014).

Aggressive gases and hightemperature solutions continually affected the lithogenic base of all fumarola fields for an extended period. These processes have completely changed the composition of loose sediments and bedrocks, being accompanied by exogenous processes and the transformation of landforms (RAzJIGAEva 2005). These resulted in denuded volcanic landscapes with destroyed or sparse vegetation (Figs A2-A7) and a buried soil cover (GANZEY 2004).

Pioneer plants very slowly colonize active fumarola fields. In this case, the high concentrations of toxic gases, rather than $\mathrm{pH}$ or soil temperature, is the main limiting factor (MANKo \& Sidelnikov 1989).

\section{Appendix 2. Studied} material

\section{Cicindela (Cicindela)}

sachalinensis sachalinensis $A$. Morawitz, 1862:

Sachalin Isl.: Ins. Sachalin, 180-I TYPE; 1 \& [ZISP]; Dolinsky district, biological station "Sokol", 1-30.vi.2005, leg. Yu. Melnikova;

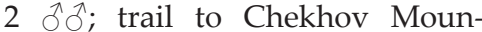
tain, $46^{\circ} 58^{\prime} 52^{\prime \prime} \mathrm{N} \quad 142^{\circ} 49^{\prime} 14^{\prime \prime} \mathrm{E}$, 26.vi.2011, leg. K. Makarov; 1 ô; south slope of Bolshevik mountain, $46^{\circ} 57^{\prime} 15^{\prime \prime} \mathrm{E} \quad 142^{\circ} 48^{\prime} 41^{\prime \prime} \mathrm{N}$, 31.vii.2017, leg. K. Makarov; 2 오; near Khomutovo, $46^{\circ} 52^{\prime} 39^{\prime \prime} \mathrm{N}$ $142^{\circ} 43^{\prime} 56^{\prime \prime} \mathrm{E}$, 25.vi.2008, leg. K. Makarov; 1 ; same, $46^{\circ} 52^{\prime} 39^{\prime \prime} \mathrm{N}$ $142^{\circ} 43^{\prime} 56^{\prime \prime} \mathrm{E}$, 27.viii.2008, leg. K. Makarov; 1 of same, $46^{\circ} 52^{\prime} 39^{\prime \prime} \mathrm{N}$ 
$142^{\circ} 43^{\prime} 56^{\prime \prime} \mathrm{E}, 17 . v i i .2011$, leg. K. Makarov; 1 q 1 ' ; $3 \mathrm{~km}$ southeast of Novikovo, $46^{\circ} 18^{\prime} 46^{\prime \prime} \mathrm{N}$

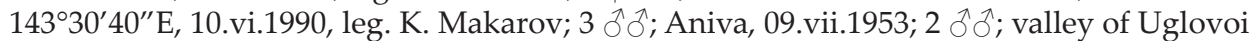
Stream, 5-6.vii.2003, leg. I. Melnik; 2 우; Korsakovskyi Kon., v.1902, leg. Pilsutsky; 1 ; near Yuzhno-Sachalinsk, 25.viii.1991, leg. I. Melnik; 1 +; Pravda vill., south of Kholmsk, 25.v.1973, leg. Kerzhner; 1 đ..

Iturup Isl.: Pioner, 19.ix.1981, leg. Kabakov; 1 i 1 ภ.

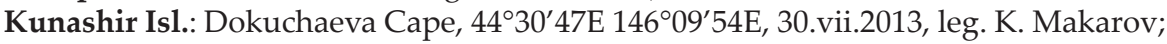

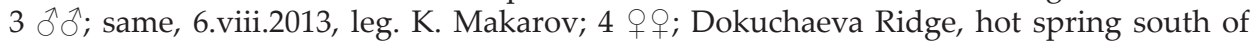

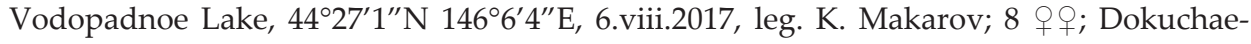
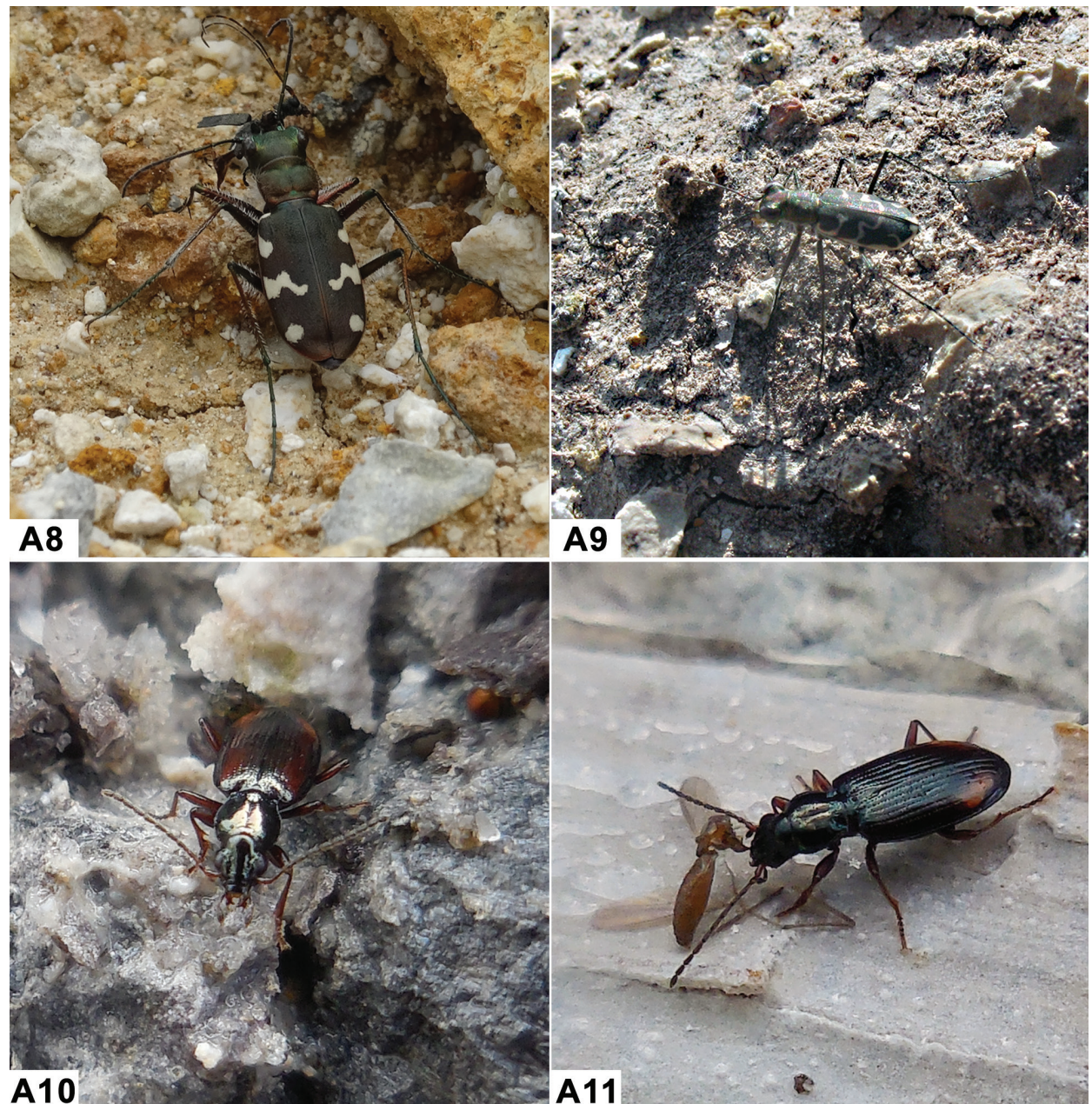

Figs A8-A11. Ground beetles on the fumarola fields of Kunashir Isl.: A8 = C. sachalinensis (Kunashir Isl., caldera of Golovnin Volcano, Kipyashcheye Lake); A9 = C. elisae elisae (Kunashir Isl., Ruruy Volcano, Neskuchenskie Streams); A10-A11 = B. dolorosum (Kunashir Isl., Dokuchaeva Mt. Ridge, solfatara field "Bolshoye") 
A12
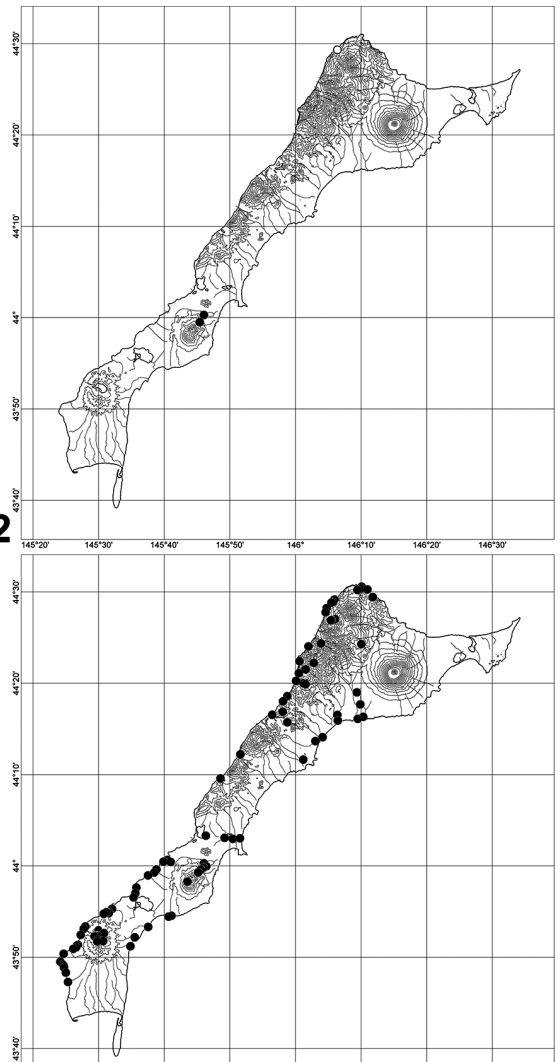

A14

A16

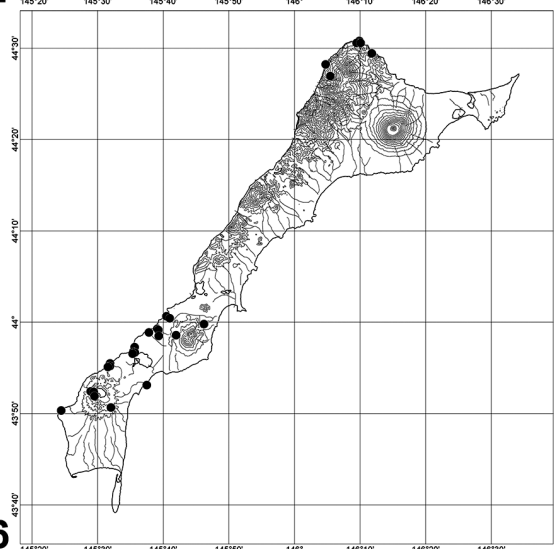

A13
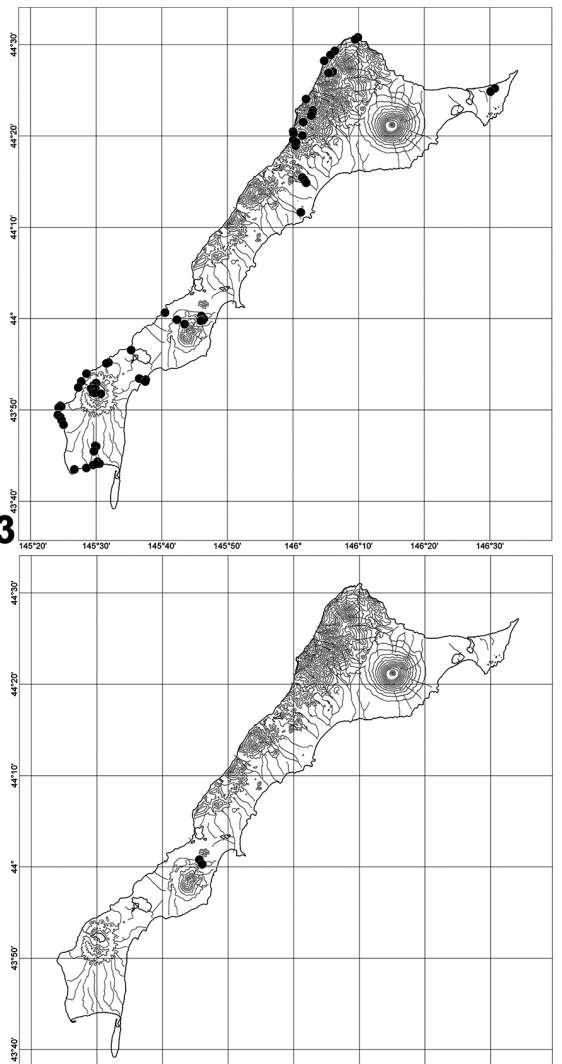

A15

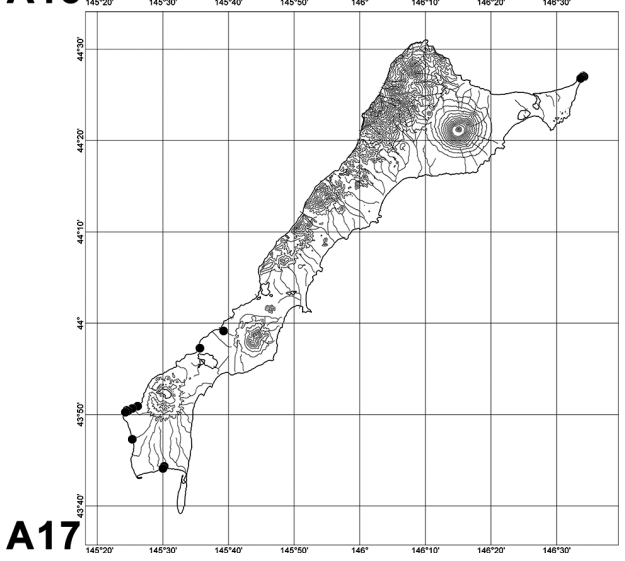

Figs A12-A17. Distribution of ground beetles on Kunashir Isl.: A12 = C. elisae (black points = C. e. kunashirensis; white point = C. e. elisae $) ; \mathrm{A} 13=$ C. sachalinensis; $\mathrm{A} 14=$ B. dolorosum; $\mathrm{A} 15=$ B. sanatum; $\mathrm{A} 16=P$. samurai; $\mathrm{A} 17=P$. fortipes 


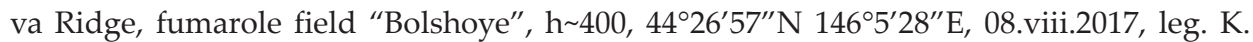

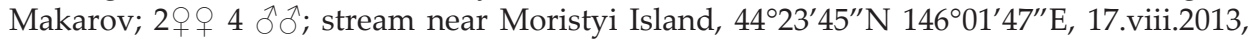

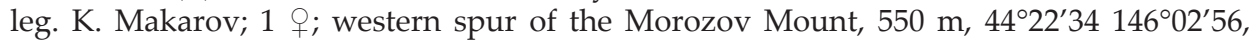
19.viii.2013, leg. K. Makarov; 3 ; ; mouth of the Zolotaya River, $44^{\circ} 20^{\prime} 48^{\prime \prime} \mathrm{N} 146^{\circ} 00^{\prime} 10^{\prime \prime} \mathrm{E}$, 15.vii.2013, leg. K. Makarov; 1 ; ; hills between Severyanka and Zolotaya rivers, $44^{\circ} 20^{\prime} 29^{\prime \prime} \mathrm{N}$ $146^{\circ} 00^{\prime} 01^{\prime \prime E}$, 1.vii.2008, leg. K. Makarov; 2 ô; right slope of Severyanka River valley, $44^{\circ} 19^{\prime} 53 \mathrm{~N} 146^{\circ} 01^{\prime} 33^{\prime \prime} \mathrm{E} 27 . v i i .2013$ leg. K. Makarov; $1 \delta^{\dagger}$; road from Rudnyi to pass

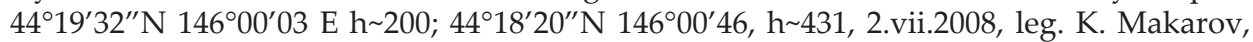

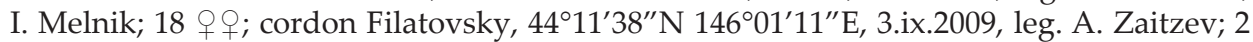

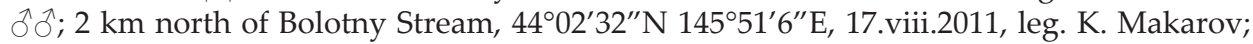

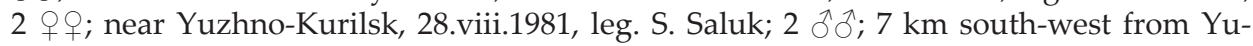

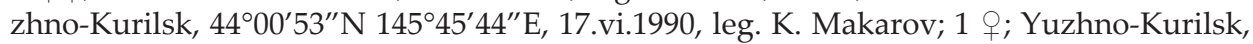
28.viii.1985, leg. B. Aristov; 1 क; south of Yuzhno-Kurilsk, 28.viii.1981, leg. Kabakov; 2 우; SW from Goryachyi Plyazh, 27.vii.1981, leg. Kabakov; 1 đ̊; Mendeleevo vill., vi.1973, leg. Kerzhner; 1 ; Mendeleev Volcano, 11.viii.1973, leg. Kerzhner; 1 đ; Kislyi Stream,

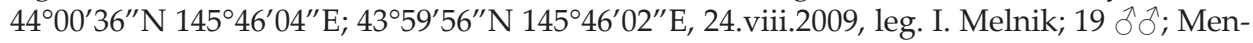
deleev Volcano, fumarole field, $43^{\circ} 59^{\prime} 40^{\prime \prime} \mathrm{N} 145^{\circ} 43^{\prime} 06^{\prime \prime} \mathrm{E}$ h $239 ; 43^{\circ} 59^{\prime} 08^{\prime \prime} \mathrm{N} 145^{\circ} 43^{\prime} 53^{\prime \prime} \mathrm{E}$ h 455, 7.viii.2008, leg. I. Melnik; 10 우; trail on Stolbovskiye hot springs, $44^{\circ} 00^{\prime} 38^{\prime \prime} \mathrm{C}$ $145^{\circ} 40^{\prime} 41^{\prime \prime E}$, 9.v.2011, leg. A. Matalin; 2 우; Stolbovskoy Stream, below hot springs,

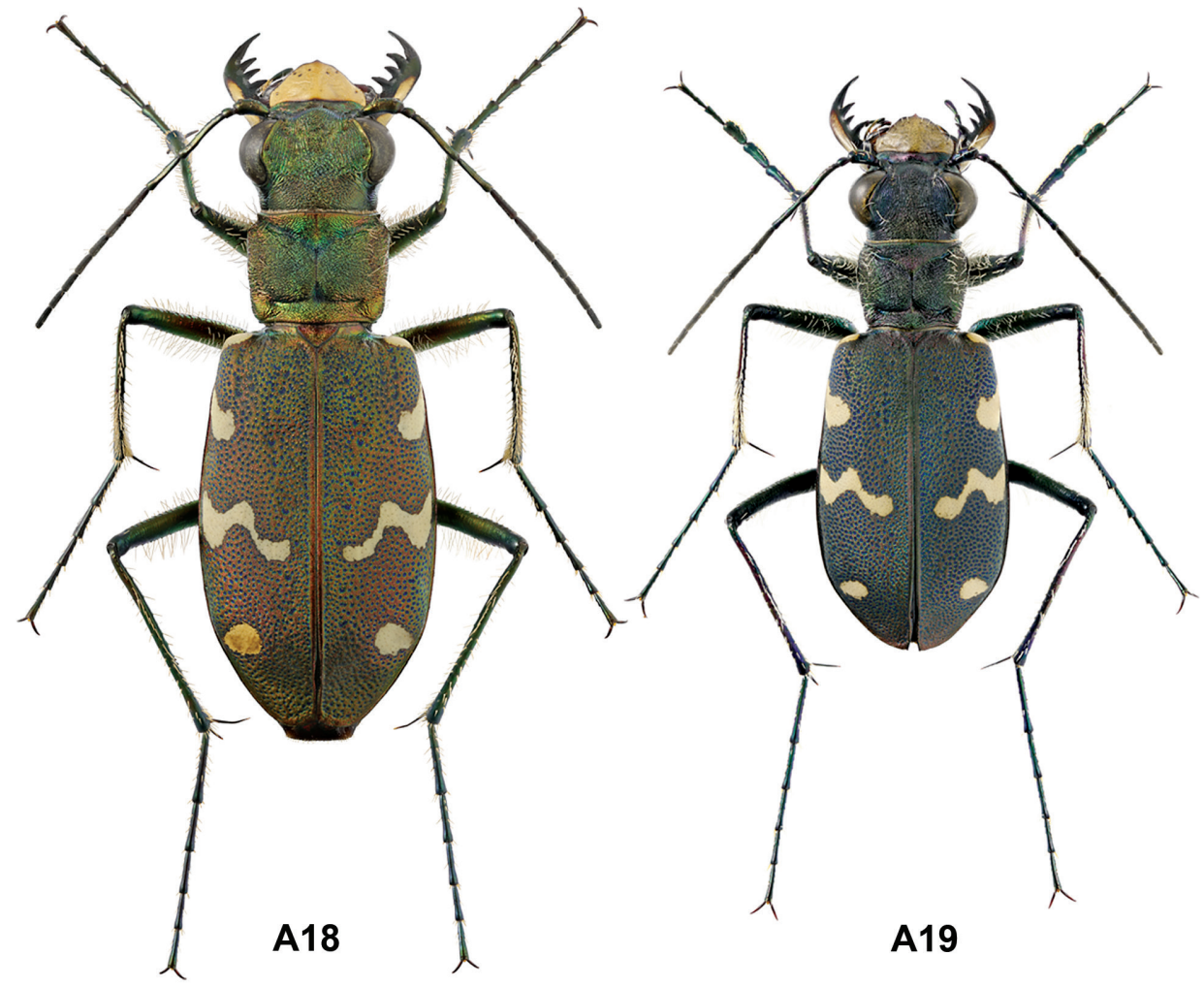

Figs A18-A19. Cicindela sachalinensis, typical (A18) and melanistic (A19) forms 
$44^{\circ} 00^{\prime} 32^{\prime \prime} \mathrm{N} 145^{\circ} 40^{\prime} 47^{\prime \prime} \mathrm{E}, 26 . v i i i .2017$, leg. K. Makarov; 4 우; valley of the Valentiny Stream, lower sulfur springs, $44^{\circ} 00^{\prime} 36^{\prime \prime} \mathrm{N} 145^{\circ} 46^{\prime} 04^{\prime \prime} \mathrm{E}$; $43^{\circ} 59^{\prime} 56^{\prime \prime} \mathrm{N} 145^{\circ} 46^{\prime} 02^{\prime \prime} \mathrm{E}$, 24.ix.2009, leg. I. Melnik; 3 우; valley of the Valentiny Stream, thermal springs, $43^{\circ} 59^{\prime} 30^{\prime \prime} \mathrm{N} 145^{\circ} 45^{\prime} 25^{\prime \prime} \mathrm{E}$,

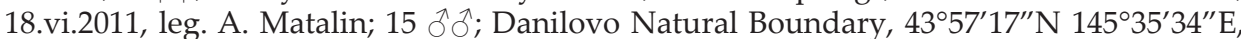
9.viii.2011, leg. K. Makarov; 1 q; same, 22.viii.2009, leg. K. Makarov; 1 q; western shore

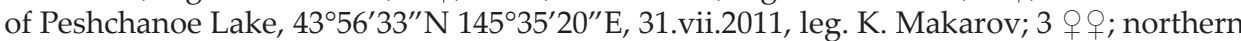

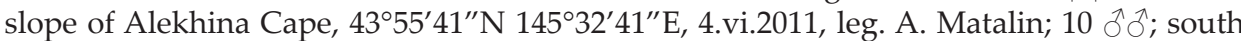
of Alekhino Outpost, Sernaya bay, on thermal, $43^{\circ} 54^{\prime} 37^{\prime \prime} \mathrm{N} 145^{\circ} 30^{\prime} 28^{\prime \prime} \mathrm{E}$, 1.vi.2011, leg. A. Matalin; 1 ; $4.5 \mathrm{~km} \mathrm{SW}$ of Alekhino, 27.vii.2011, leg. K. Makarov; 1 ; ; mouth of the Oz-

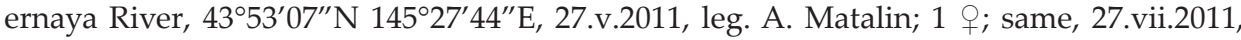
leg. K. Makarov; 2 q $9 ; 1.5 \mathrm{~km}$ south-west from mouth of the Ozernaya River, $43^{\circ} 52^{\prime} 27^{\prime \prime} \mathrm{N}$

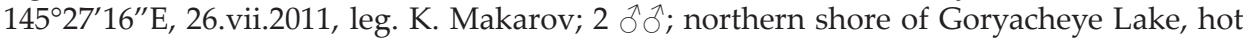

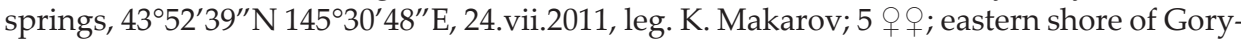

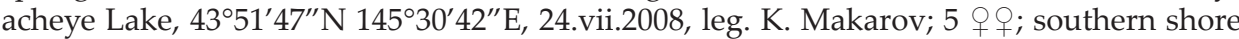
of Goryacheye Lake, fumarolas, $43^{\circ} 52^{\prime} 19^{\prime \prime} \mathrm{N} 145^{\circ} 29^{\prime} 45^{\prime \prime} \mathrm{E}$, 13.vii.2008, leg. K. Makarov; 16

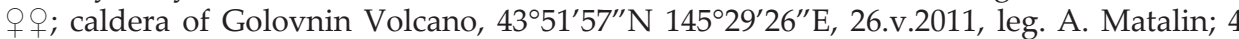

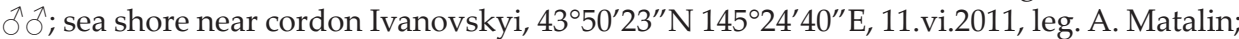

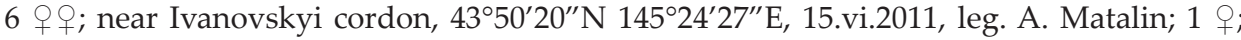

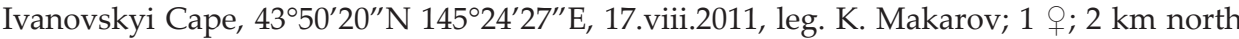
of Dubovoe, $43^{\circ} 46^{\prime} 44^{\prime \prime} \mathrm{N} 145^{\circ} 29^{\prime} 44^{\prime \prime} \mathrm{E}, 24 . v i i i .2017$, leg. K. Makarov; 4 웅 near Paltusovo, $43^{\circ} 44^{\prime} 19^{\prime \prime} \mathrm{N} 145^{\circ} 25^{\prime} 25^{\prime \prime} \mathrm{E}, 16 . v i .2011$, leg. A. Matalin; $3 \mathrm{o}^{\prime}$; watershed of the Golovnin and

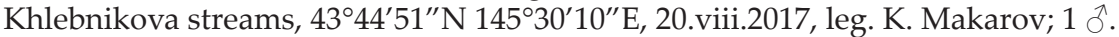

Shikotan Isl.: Sikotan, A. Diakonov, 9.ix.1949; 1 ; ; valley of the Otrada River, $43^{\circ} 51^{\prime} 10^{\prime \prime} \mathrm{N} 146^{\circ} 50^{\prime} 54^{\prime \prime} \mathrm{E}, \mathrm{h} 45$, 22.vi.2011, leg. I. Melnik; $2 \delta^{\prime}$; hills along the valley of the

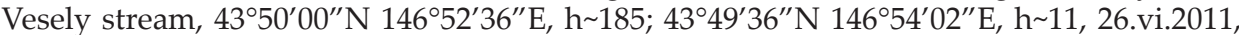
leg. I. Melnik; 11 오; northern outskirts of the village of Krabozavodskoe, $43^{\circ} 49^{\prime} 56^{\prime \prime} \mathrm{N}$ $146^{\circ} 44^{\prime} 47^{\prime \prime} \mathrm{E}, \mathrm{h} \sim 63$, 28.vi.2011, leg. I. Melnik; 1 ; ; pass the Tserkovnaya bay; source of the

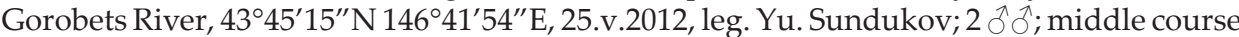

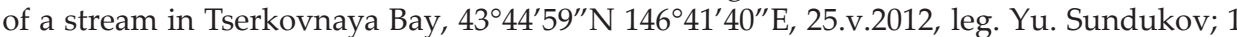

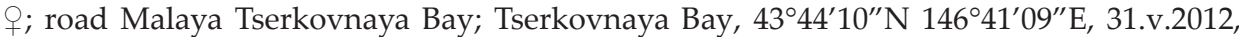
leg. Yu. Sundukov; 1 ㅇ, 1 ; ; road to the Tserkovnaya Bay, leg. A. Strelkov, 08.ix.1949; 2 ㅇ

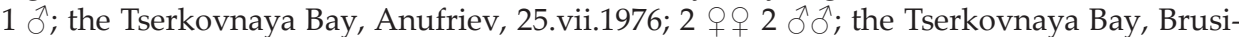

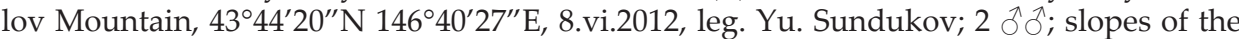
hills north of Anama (Krabovaya) Bay, A. Strelkov, 5.viii.1949; 1 ; ; upper reaches of the Gorobets River, $43^{\circ} 46^{\prime} 34^{\prime \prime} \mathrm{N} 146^{\circ} 42^{\prime} 43^{\prime \prime} \mathrm{E}, 28 . i x .2012$, leg. Yu. Sundukov; $1 \mathrm{o}^{\hat{0}}$.

\section{Cylindera (Eugrapha) elisae (Motschulsky, 1859)}

\section{C. elisae elisae:}

China: North China, 6-7.viil.14, leg. Yu. Vasiliev; 1 ; ; Manchuria, Langashi, 20.vi-11. vii.905, leg. A.Yakovlev; 2 ổ; Pekin; 1 ㅇ 1ठ; Peking, Staud., 1889; 2 우; Peking, Herz; 2

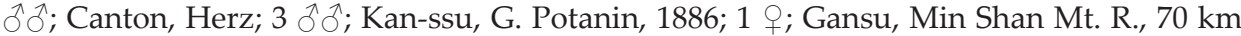
NW Wudu, h 2100 m, 1-10.vi.1997, leg. A. Gorodinski; 1 ㅇ.

Russian Far East: Amur Area, near Blagoveshensk, left bank of Zeya River, 21.vii.1997, leg. A. A. Kuzmin; 1 ; ; Korsakovo na Amure, 100 km W Svobodnoe, 7.viii.1959, leg. Falko-

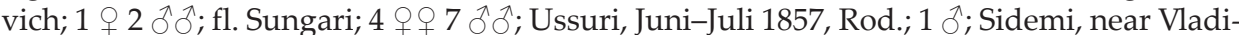

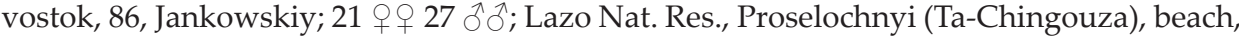


$43^{\circ} 00^{\prime} 34^{\prime \prime} \mathrm{N} 134^{\circ} 07^{\prime} 43^{\prime \prime} \mathrm{E}, 17-22 . v i i i .2007$, leg. K. Makarov, A. Zaitsev; 1 +; Kedrovaya Pad' Nat. Res., 7.viii.1978, leg. Stepanov; 1 đ.. $2 \hat{\jmath}$.

Sachalin Isl.: Susuya River, near Lugovoe vill., 26.viii.2010, leg. A. Vertyankin; 2 qㅇ

Kunasir Isl.: Ruruy Volcano, thermal fields, $\sim 1 \mathrm{~km} \mathrm{~N}$ of the Dalnie Streams,

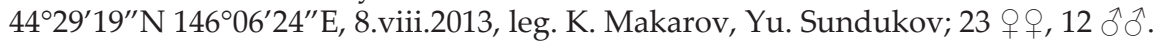

C. elisae novitia:

Japan: Okinawa Met., Ishigaki Isl., Maehama, vi.1974, leg. S. Nakamura; 1 1 ภ.

C. elisae mikurana:

Japan: Tokyo Met., Hacnijojima Isl., Sueyoshi-Noboru Pass., 18-22.vii.1985. leg. M. Nishimura; 1 ふै; Tokyo Met., Konzushima Isl., near Tsuzukido, 31.vii.1983, leg. M. Nishimura; 1 万; Tokyo, Bodemeyer -2 우요.

C. elisae kunashirensis:

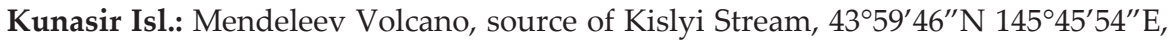
19.vi.1990, leg. I. Melnik, K. Makarov; 4 우우, 2 수 수; Mendeleev Volcano, Kislyi Stream, 2-3. ix.1992, leg. A. Sokolov; 2 우, 1 o; Mendeleev Volcano, Kislyi Stream below hot springs,

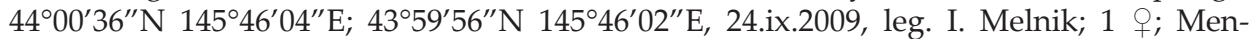
deleev Volcano, Kislyi Stream below hot springs, $44^{\circ} 00^{\prime} 36^{\prime \prime} \mathrm{N} 145^{\circ} 46^{\prime} 04^{\prime \prime} \mathrm{E}$; $43^{\circ} 59^{\prime} 56^{\prime \prime} \mathrm{N}$

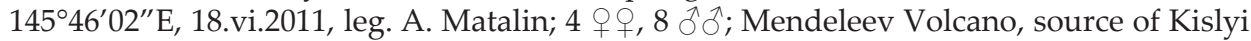
Stream below the solfatara field, $43^{\circ} 59^{\prime} 46^{\prime \prime} \mathrm{N} 145^{\circ} 45^{\prime} 54^{\prime \prime} \mathrm{E}, 15 . v i i .2017$, leg. Yu. Sundukov, L. Sundukova; 7 우, $9 \hat{\jmath}$.

\section{Bembidion (Ocydromus) dolorosum (Motschulsky, 1860):}

Urup Isl.: Ukromnaya Bay, seashore rocky debris, 20.viii.1996, leg. K. Eskov; 2 ๙ิ ô.

Kinashir Isl.: $2.5 \mathrm{~km}$ NW of Cape Nelyudimyi, $44^{\circ} 29^{\prime} 26^{\prime \prime} \mathrm{N} 146^{\circ} 11^{\prime} 47^{\prime \prime} \mathrm{E}$, 2.viii.2013,

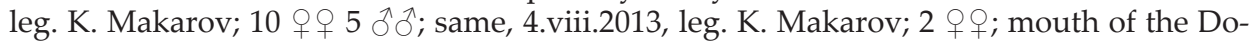
kuchaev River, $44^{\circ} 30^{\prime} 16^{\prime \prime} \mathrm{N} 146^{\circ} 10^{\prime} 58^{\prime \prime} \mathrm{E}, 30 . v i i .2013$, leg. K. Makarov; 2 우 1 `’; Cape Belyy

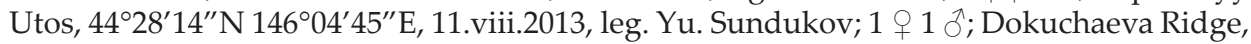

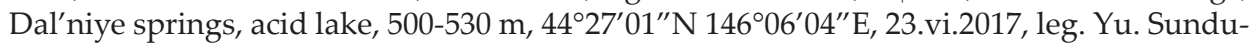

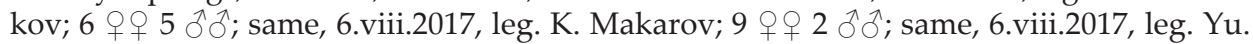

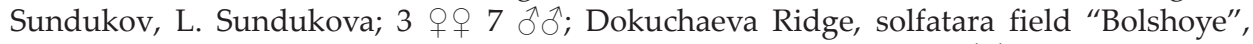

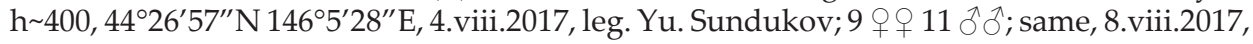

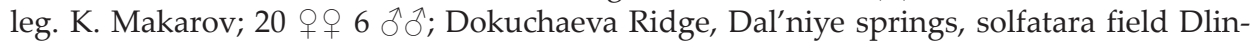
noye, $400 \mathrm{~m}, 44^{\circ} 26^{\prime} 54^{\prime \prime} \mathrm{N} 146^{\circ} 5^{\prime} 24^{\prime \prime} \mathrm{E}, 21 . v i .2017$, leg. Yu. Sundukov; 3 우 2 o $^{\lambda} \delta^{\wedge}$; Dokuchaeva Ridge, E slope, Williams Lake, $535 \mathrm{~m}, 4^{\circ} 24^{\prime} 10^{\prime \prime} \mathrm{N} 146^{\circ} 10^{\prime} 06^{\prime \prime} \mathrm{E}, 23 . i x .2017$, leg. Yu. Sun-

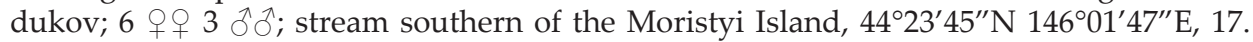
viii.2013, leg. K. Makarov; 1 ㅇ 1 `ं rocky brook south of Prasolov Cape, $44^{\circ} 21^{\prime} 15^{\prime \prime} \mathrm{N}$

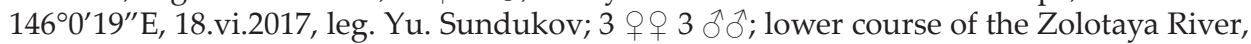
$44^{\circ} 21^{\prime} 06^{\prime \prime} \mathrm{N} 146^{\circ} 00^{\prime} 31^{\prime \prime} \mathrm{E}, 30 . v i .2008$, leg. I. Melnik; 1 '̊; same, 24.vii.2013, leg. K. Makarov;

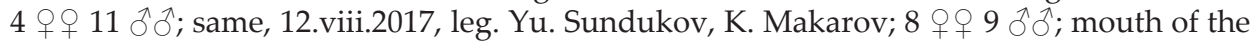

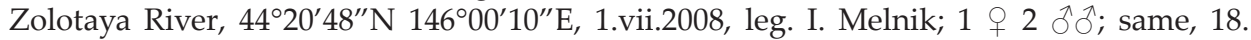
vi.2017, leg. Yu. Sundukov; 2 우 1 d ; same, 11.viii.2017, leg. K. Makarov; 1 '; mouth of the Severyanka River, $44^{\circ} 19^{\prime} 58^{\prime \prime} \mathrm{N} 146^{\circ} 01^{\prime} 15^{\prime \prime} \mathrm{E}, 15 . v i .2017$, leg. Yu. Sundukov; 2 우 $30^{\wedge} \mathrm{o}^{\prime}$; lower course of the Severyanka River, $44^{\circ} 19^{\prime} 58^{\prime \prime} \mathrm{N} 146^{\circ} 01^{\prime} 15^{\prime \prime} \mathrm{E}, 17 . v i .2014$, leg. Yu. Sundukov;

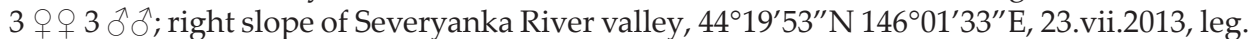

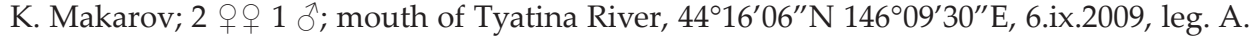



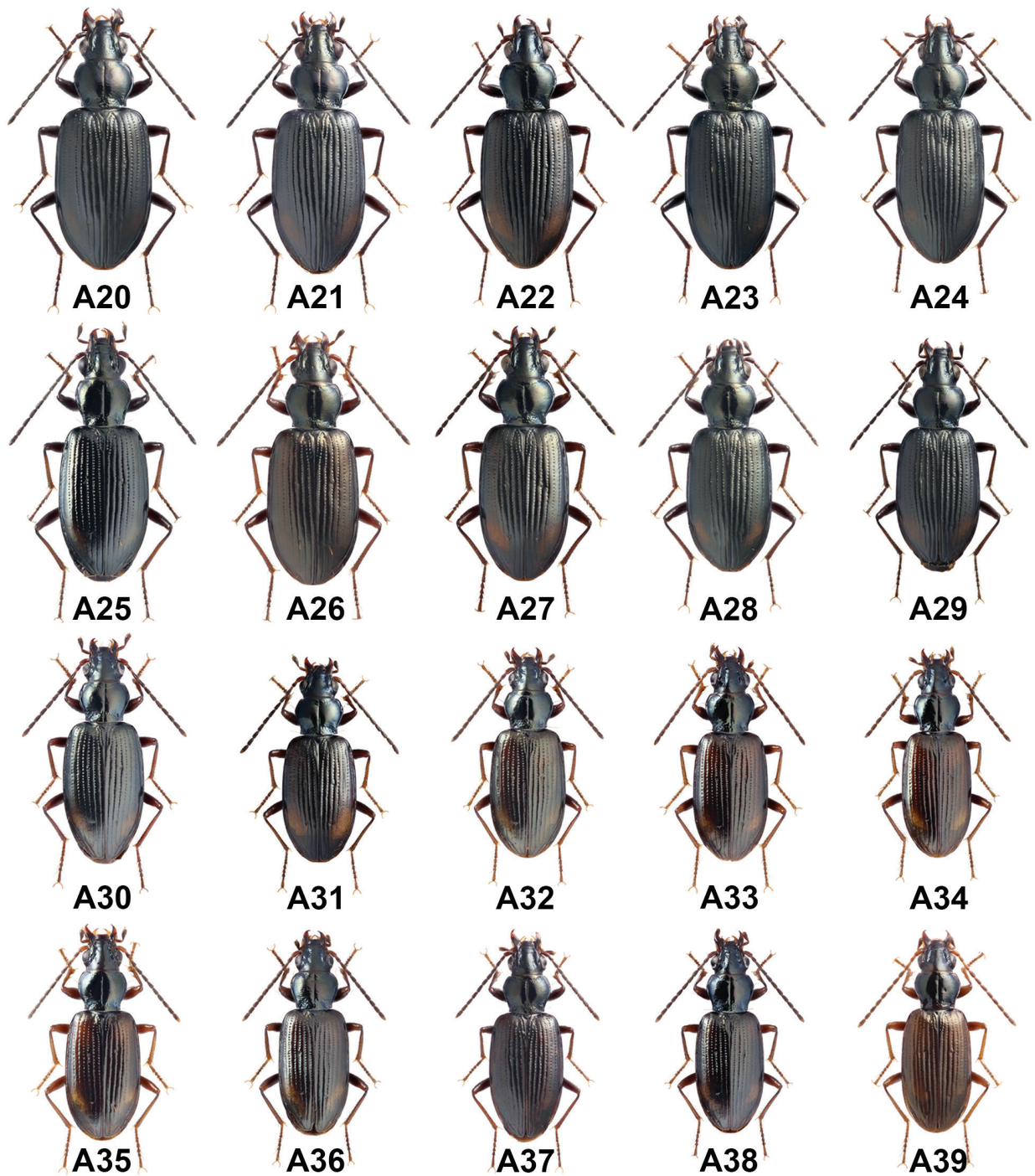

Figs A20-A39. Variability B. dolorosum, females: A20 = Kunashir Isl., mouth of the Ozernaya River; A21 = Kunashir Isl., mouth of the Mednyi Stream; A22 = Sakhalin Isl., near Khomutovo; A23 = Sakhalin Isl., Rogatka River; A24 = Kunashir Isl., caldera of Golovnin Volcano, near cordon Ozernyi; A25 = Yuriy Isl., Shirokaya Bay; A26 = Kunashir Isl., Mendeleev Volcano, mouth of Kislyi Stream; A27, A31 = Kunashir Isl., Dokuchaeva Mt. Ridge, solfatara field "Bolshoye"; A28, A29 = Shikotan Isl., Tserkovnaya Bay; A30, A32-A34, A36, A37 = Kunashir Isl., caldera of Golovnin Volcano, solfatara field "Cherepakhovoye"; A35, A39 = Kunashir Isl., Mendeleev Volcano, source of Kislyi Stream; A38 = Kunashir Isl., caldera of Golovnin Volcano, Kipyashcheye Lake (loc. typ. B. kuznetsovi) 


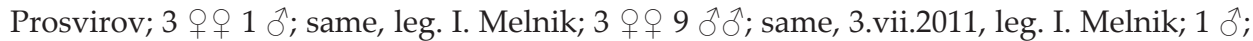
valley of the Tyatina River, 1-2 km upstream of mouth, $44^{\circ} 19^{\prime} 30^{\prime \prime} \mathrm{N} 146^{\circ} 09^{\prime} 17^{\prime \prime} \mathrm{E}$, 7.vi.2016, leg. Yu. Sundukov; 1 + 4 ôं ; valley of the Tyatina River, 10-18 km upstream of mouth, $44^{\circ} 19^{\prime} 27^{\prime \prime} \mathrm{N} 146^{\circ} 09^{\prime} 11^{\prime \prime} \mathrm{E}, 22-24.1 x .2017$, leg. Yu. Sundukov; 2 우 1 `’; lower reaches of the Saratovskaya River, riverside, $44^{\circ} 15^{\prime} 46^{\prime \prime} \mathrm{N} 146^{\circ} 06^{\prime} 13^{\prime \prime} \mathrm{E}, 15 . v i .2016$, leg. Yu. Sundukov; 5 우

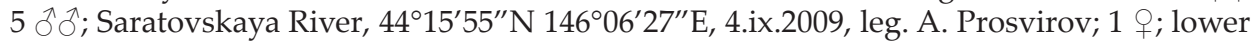
reaches of the Saratovskaya River ca. $3 \mathrm{~km}$ upstream of mouth, $44^{\circ} 15^{\prime} 46^{\prime \prime} \mathrm{N} 146^{\circ} 06^{\prime} 13^{\prime \prime} \mathrm{E}$,

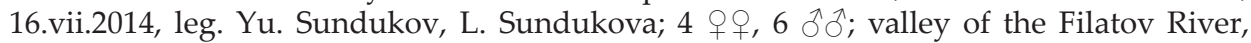
$44^{\circ} 11^{\prime} 38^{\prime \prime} \mathrm{N} 146^{\circ} 01^{\prime} 11^{\prime \prime}$ E, 2.ix.2009, leg. I. Melnik; 1 `’; same, 10.ix.2009, leg. I. Melnik; 1 ㅇ; Mikhaylovskoye Lake, $44^{\circ} 18^{\prime} 01^{\prime \prime} \mathrm{N} 145^{\circ} 58^{\prime} 07^{\prime \prime} \mathrm{E}, 14$.viii.2017, leg. Yu. Sundukov, K. Ma-

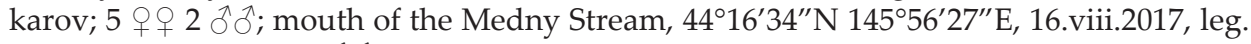

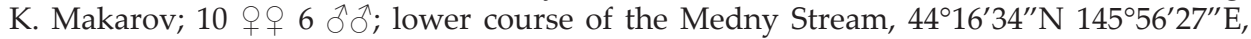
16.viii.2017, leg. Yu. Sundukov; 3 우우 2 ठㅊㅎㄱ; lower reaches of the Polynova stream,

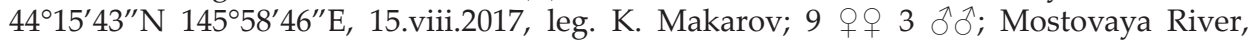
$44^{\circ} 13^{\prime} 14^{\prime \prime} \mathrm{N} 146^{\circ} 03^{\prime} 03^{\prime \prime} \mathrm{E}, 9 . i x .2009$, leg. A. Prosvirov; 1 우 2 o $^{\wedge}$; mouth of the Nazarova

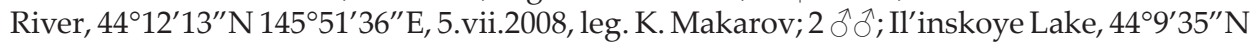
1454'34"E, 17.viii.2017, leg. K. Makarov; 6 우; same, 17.viii.2017, leg. Yu. Sundukov; 6 ${ }^{\lambda} \delta^{\prime}$; mouth of Petrova River, $44^{\circ} 4^{\prime} 13^{\prime \prime} \mathrm{N} 145^{\circ} 52^{\prime} 07^{\prime \prime} \mathrm{E}, 25 . v i i i .2017$, leg. K. Makarov; 5 우 5

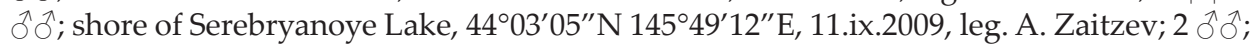
same, 12.ix.2009, leg. I. Melnik; 2 우 1 ठ; same, 12.ix.2009, leg. A. Prosvirov; 1 ㅇ 1 ठ; Men-

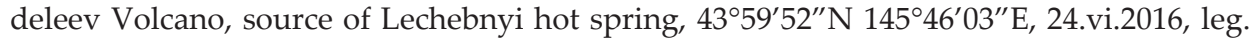
Yu. Sundukov, L. Sundukova; 1 1 ô; same, 16.vii.2017, leg. Yu. Sundukov, L. Sundukova; 2 우 1 `ं; Mendeleev Volcano, Kislyi Stream below hot springs, $44^{\circ} 00^{\prime} 36^{\prime \prime} \mathrm{N} 145^{\circ} 46^{\prime} 04^{\prime \prime} \mathrm{E}$

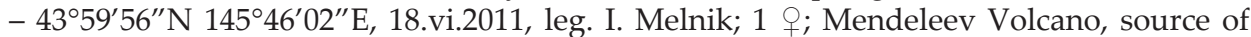
Kislyi Stream below the solfatara field, $43^{\circ} 59^{\prime} 46^{\prime \prime} \mathrm{N} 145^{\circ} 45^{\prime} 54^{\prime \prime} \mathrm{E}, 15 . v i i .2017$, leg. Yu. Sundukov, L. Sundukova; 5 오 5 ô ; ; same, 3.viii.2016, leg. Yu. Sundukov, L. Sundukova; 7

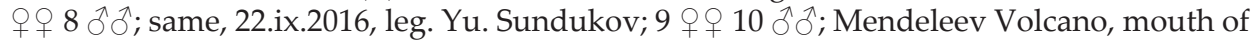

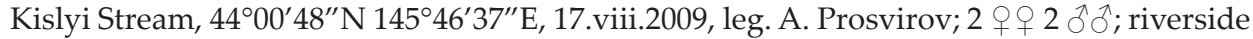
of Lesnaya River, $44^{\circ} 00^{\prime} 48^{\prime \prime} \mathrm{N} 145^{\circ} 46^{\prime} 37^{\prime \prime} \mathrm{E}$, 17.viii.2009, leg. A. Prosvirov; 1 `ं; mouth of Lesnaya River, $44^{\circ} 00^{\prime} 47^{\prime \prime} \mathrm{N} 145^{\circ} 48^{\prime} 34^{\prime \prime} \mathrm{E}$, 17.viii.2009, leg. K. Makarov; $10^{\prime}$; mouth of the

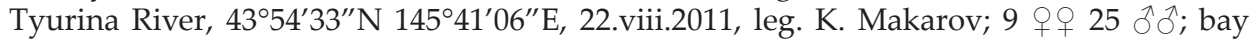

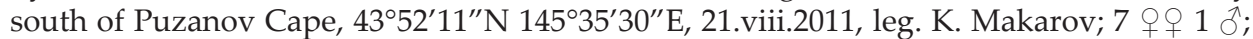

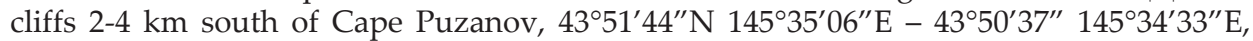

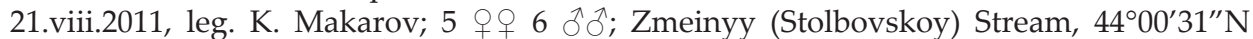

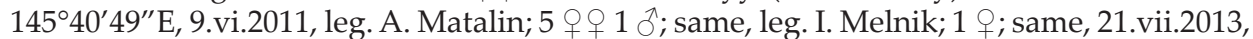

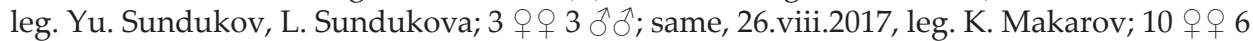

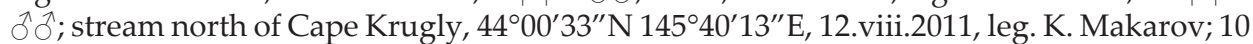
우우 3 ठํ; ; valley of the Valentiny Stream near Tretyakovo, $44^{\circ} 00^{\prime} 36^{\prime \prime} \mathrm{N} 145^{\circ} 46^{\prime} 04^{\prime \prime} \mathrm{E}, 17$. viii.2008, leg. I. Melnik; 1 §ं; same, 21.viii.2013, leg. K. Makarov; 3 우; mouth of the Val-

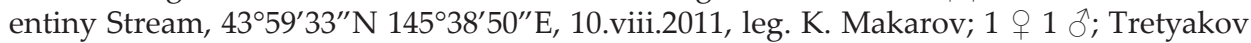

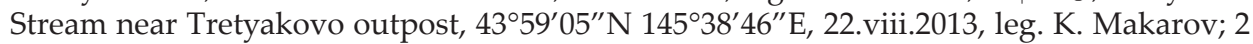
우 2 ठえ

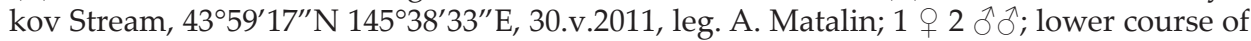

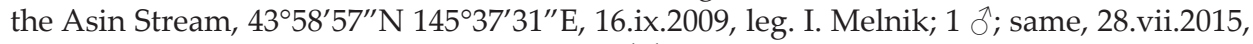

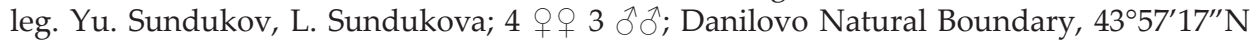
$145^{\circ} 35^{\prime} 34^{\prime \prime}$ E, 29.vii-6.viii.2008, leg. I. Melnik; 1 우 western shore of Peshchanoe Lake, $43^{\circ} 56^{\prime} 33^{\prime \prime} \mathrm{N} 145^{\circ} 35^{\prime} 20^{\prime \prime} \mathrm{E}, 6 . v i i i .2008$, leg. I. Melnik; 3 우 2 ふे $^{\wedge}$; mouth of the Alekhina Riv-

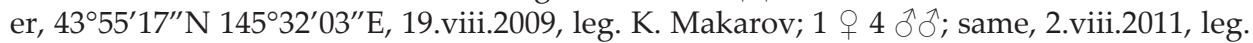




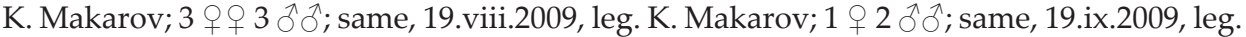
A. Prosvirov; 5 ठิ ; warm thermal hollow next to the hot stream "Imperial spring" south

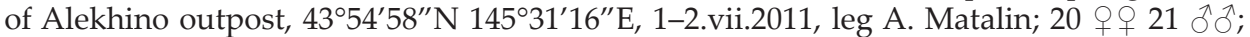

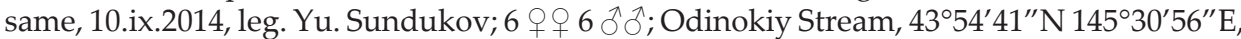
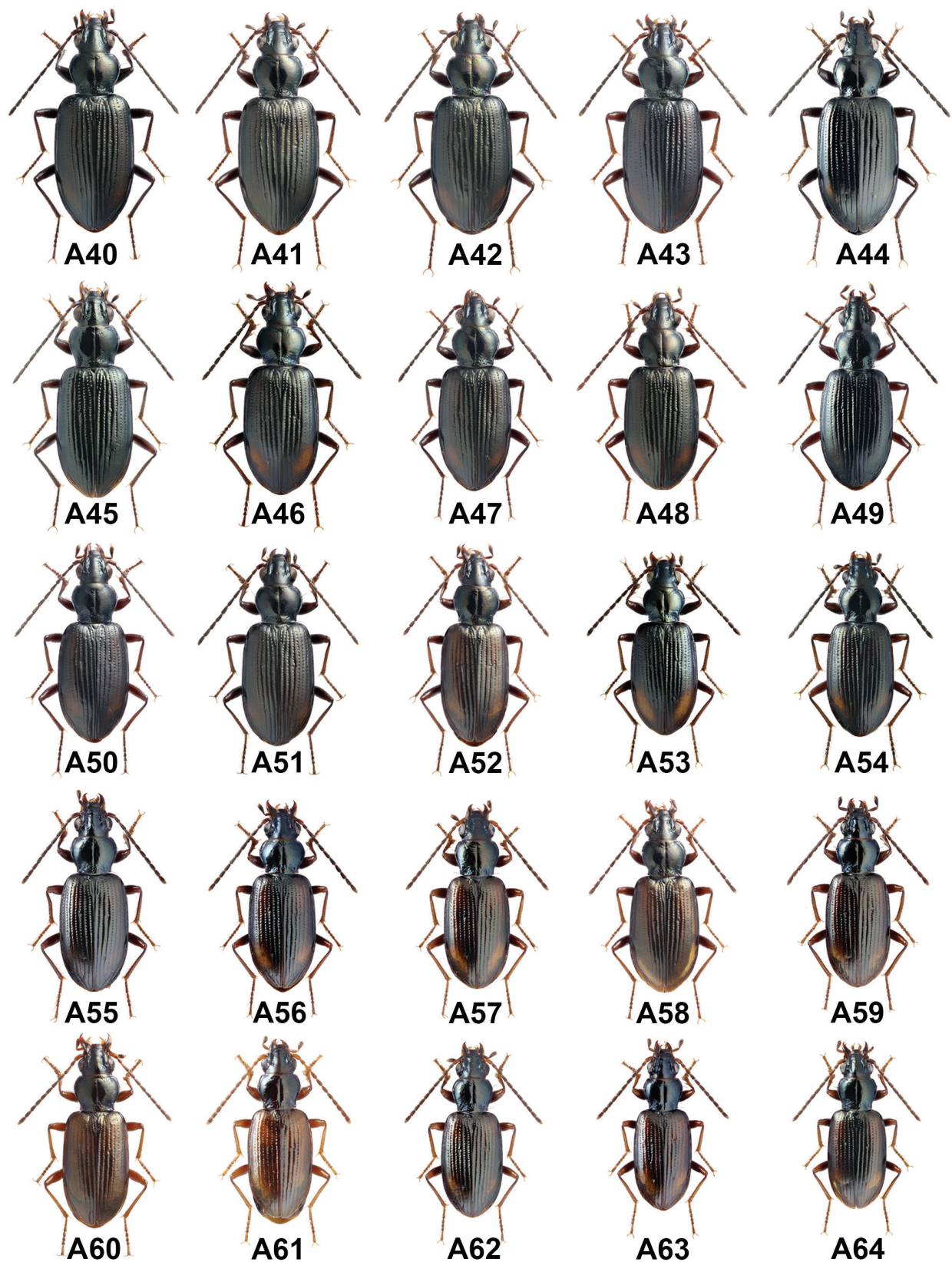


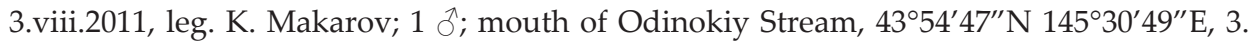

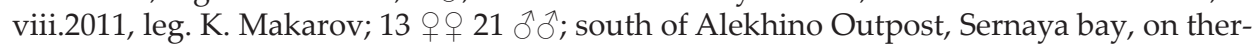

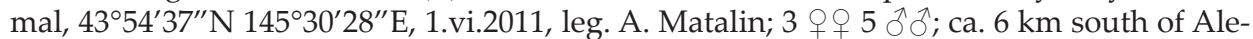

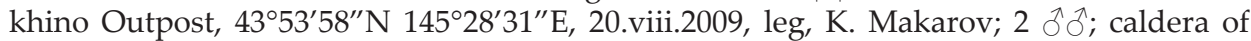
Golovnin Volcano, eastern shore of Goryacheye Lake, 43 $51^{\prime} 47^{\prime \prime} \mathrm{N} 145^{\circ} 30^{\prime} 42^{\prime \prime} \mathrm{E}$, 24.vi.2008,

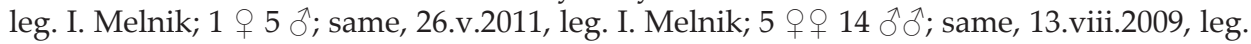
K. Makarov; 1 + 16 $\widehat{\jmath}$; caldera of Golovnin Volcano, northern shore of Goryacheye Lake,

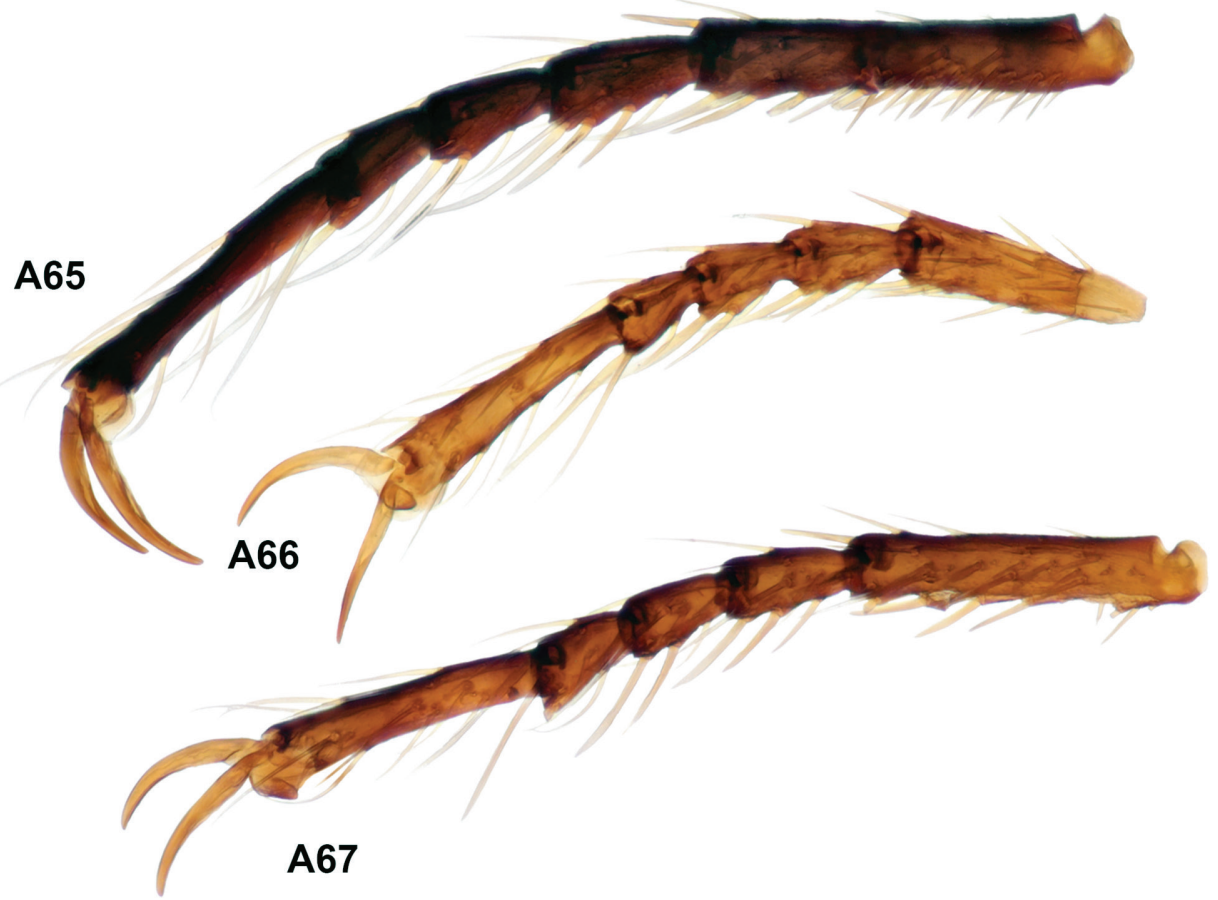

Figs A65-A67. The tarsi of B. dolorosum inhabiting solfatara fields (A66, A67) and ordinary habitats (A65): A65 = Kunashir Isl., mouth of the Ozernaya River; A66 = Kunashir Isl., caldera of Golovnin Volcano, solfatara field "Cherepakhovoye"; A67 = Kunashir Isl., caldera of Golovnin Volcano, eastern shore of Goryacheye Lake

Figs A40-A64. Variability B. dolorosum, males: A40 = Sakhalin Isl., Rogatka River; A41 = Kunashir Isl., mouth of the Ozernaya River; A42, A51 = Sakhalin Isl., near Khomutovo; A43 = Kunashir Isl., Mendeleev Volcano, mouth of Kislyi Stream; A44 = Kunashir Isl., Zmeinyy (Stolbovskoy) Stream; A45 = Kunashir Isl., mouth of the Mednyi Stream; A46, A53, A54 = Kunashir Isl., Dokuchaeva Mt. Ridge, solfatara field "Bolshoye"; A47 = Sakhalin Isl., near Khomutovo; A48 = Kunashir Isl., caldera of Golovnin Volcano, near cordon Ozernyi; A49, A50, A52 = Yuriy Isl., Shirokaya Bay; A55, A56, A57, A59, A62-A64 = Kunashir Isl., caldera of Golovnin Volcano, solfatara field "Cherepakhovoye"; A58 = Kunashir Isl., caldera of Golovnin Volcano, Kipyashcheye Lake (loc. typ. B. kuznetsovi); A60, A61 = Kunashir Isl., Mendeleev Volcano, source of Kislyi Stream 

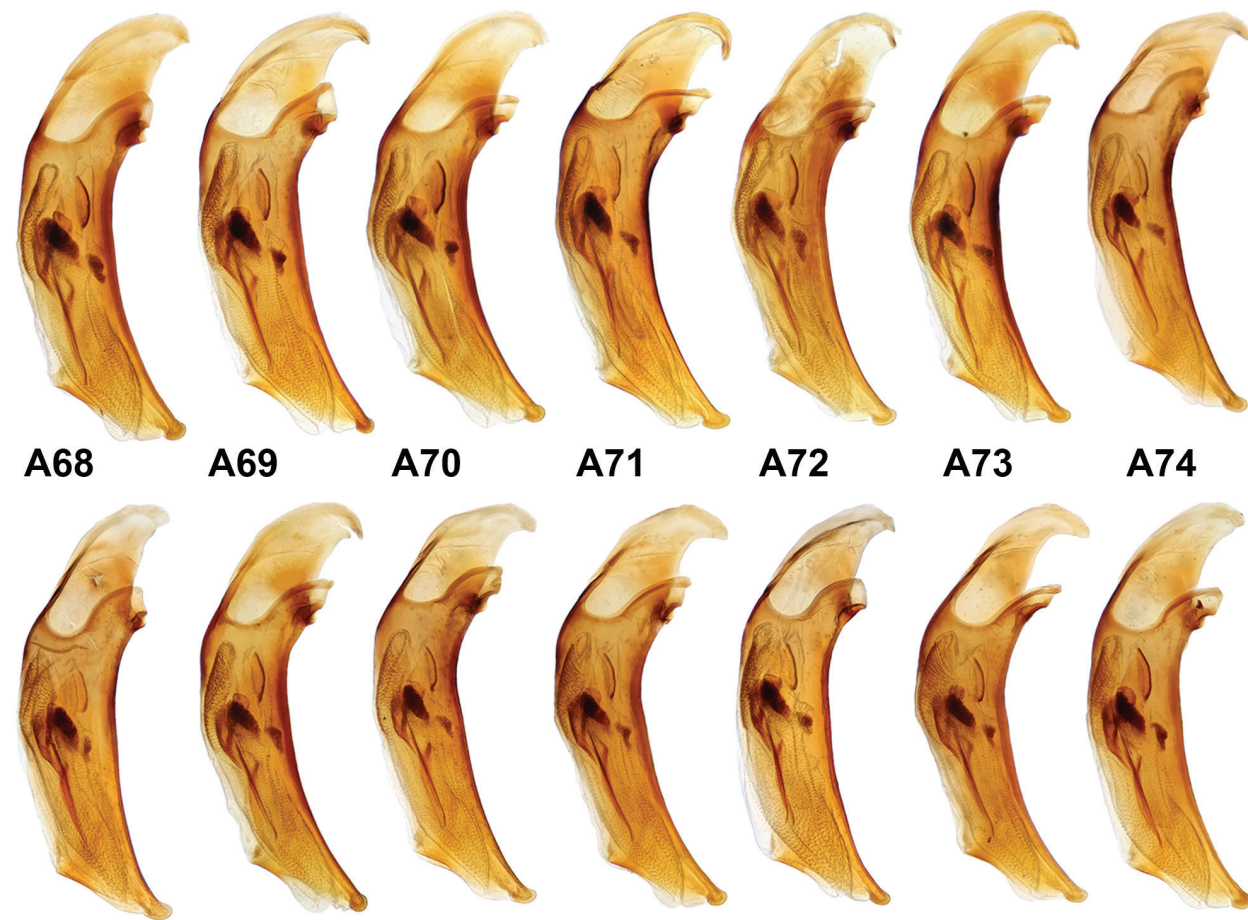

A70

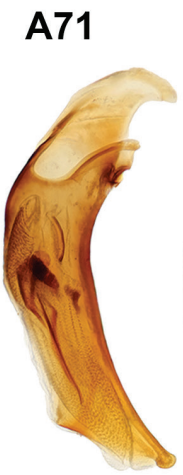

A72

A73

A74

A75

\section{A76}
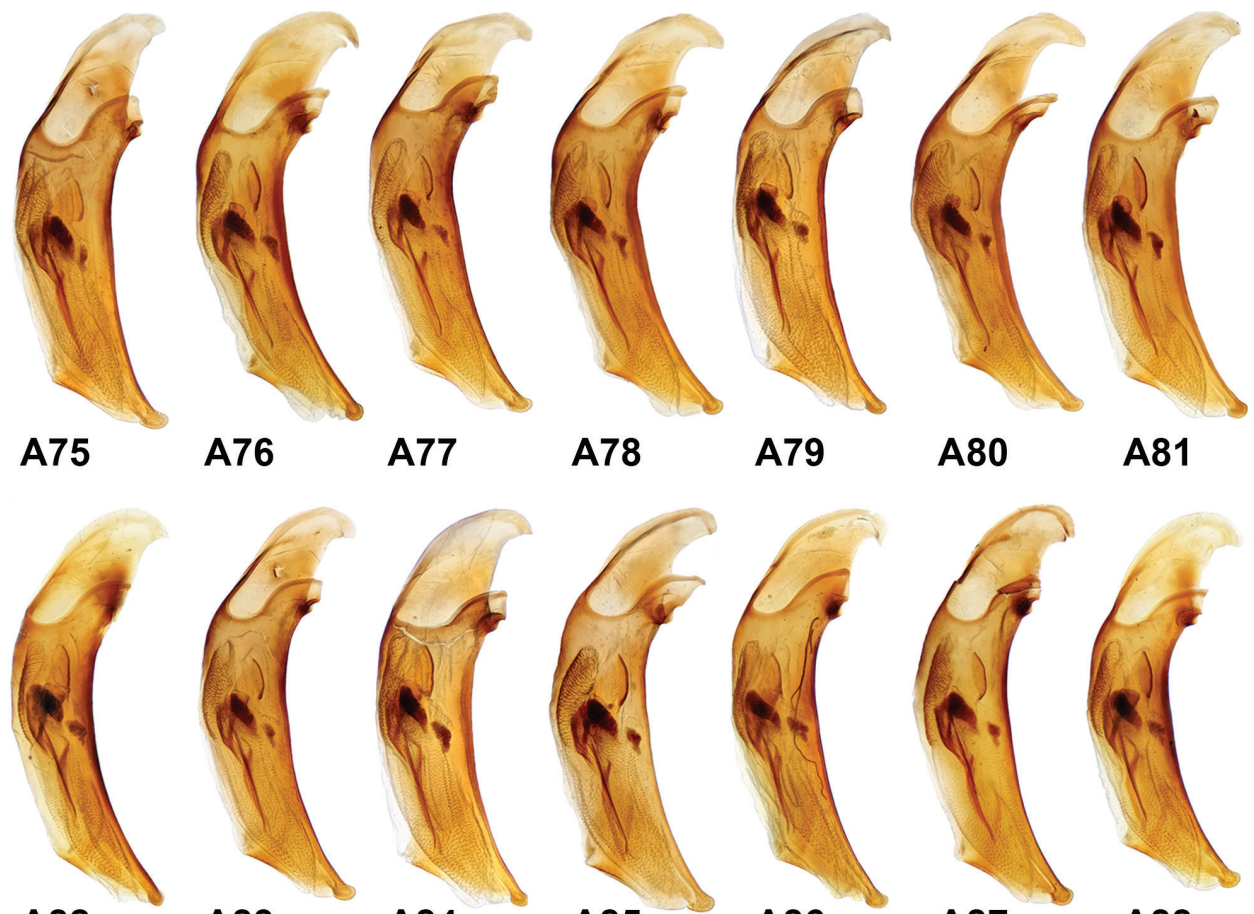

A77

A78

A79

A80

A81

A82
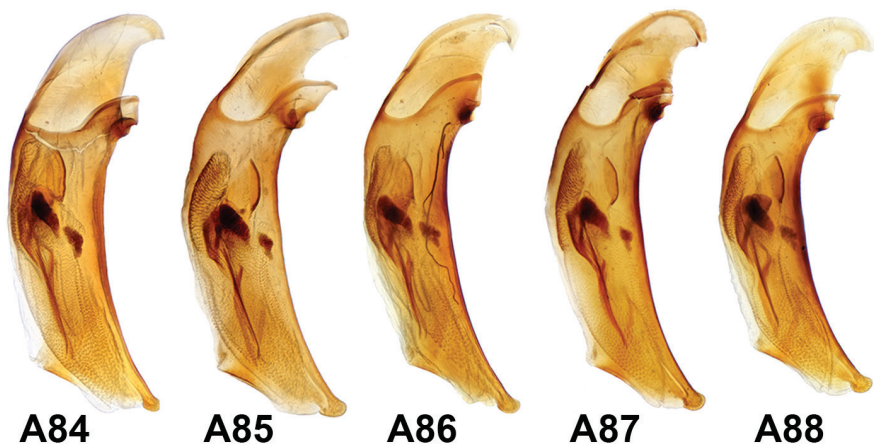

A87

A88

Figs A68-A88. Variability of the shape and size of the aedeagus B. dolorosum: A68, A73 = Shikotan Isl., Tserkovnaya Bay; A69 = Kunashir Isl., Zmeinyy (Stolbovskoy) Stream; A70 = Kunashir Isl., mouth of the Ozernaya River; A71 = Sakhalin Isl., Rogatka River; A72, A74, A75, A77, = Kunashir Isl., Mendeleev Volcano, mouth of Kislyi Stream; A79, A83, A84 = Kunashir Isl., Mendeleev Volcano, source of Kislyi Stream; A76 = Kunashir Isl., caldera of Golovnin Volcano, Kipyashcheye Lake (loc. typ. B. kuznetsovi); A78, A80, A81 = Yuriy Isl., Shirokaya Bay; A82, A86, A88 = Kunashir Isl., caldera of Golovnin Volcano, solfatara field "Cherepakhovoye"; A85 = Kunashir Isl., mouth of the Mednyi Stream; A87 = Kunashir Isl., Dokuchaeva Mt. Ridge, solfatara field "Bolshoye" 


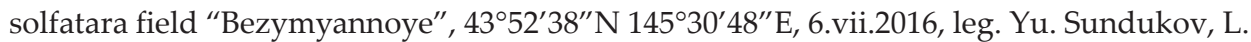
Sundukova; 12 우 10 गे $\mathrm{o}^{\text {; }}$; caldera of Golovnin Volcano, solfatara field "Cherepakhovoye",

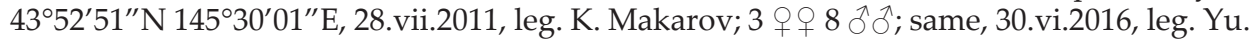
Sundukov, L. Sundukova; 1 q, 4 ô; caldera of Golovnin Volcano, solfatara field of the

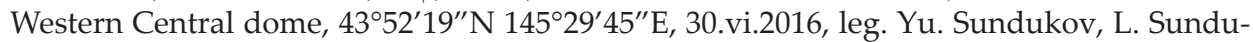

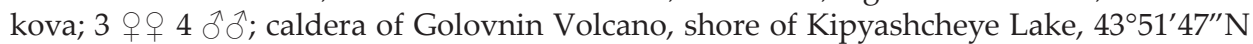
$145^{\circ} 30^{\prime} 04^{\prime \prime}$, 24.vi.2008, leg. K. Makarov; 1 ㅇ 1 के; caldera of Golovnin Volcano, south-west

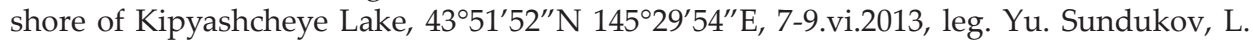

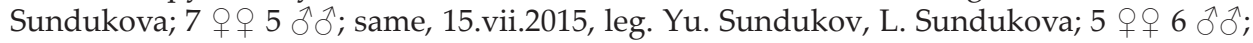
same, 5.ix.2015, leg. Yu. Sundukov; 3 우 4 $\widehat{\partial} \widehat{\delta}^{\hat{*}}$; caldera of Golovnin Volcano, southern shore of Goryacheye Lake western of the Central West Dome, 435' $17^{\prime \prime} \mathrm{N} 145^{\circ} 29^{\prime} 26^{\prime \prime} \mathrm{E}, 7$.

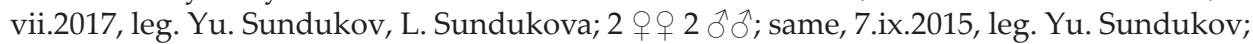
1 ; ; same, 11.ix.2015, leg. Yu. Sundukov; 1 क 1 के; caldera of Golovnin Volcano, near Gory-

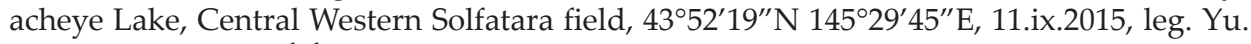

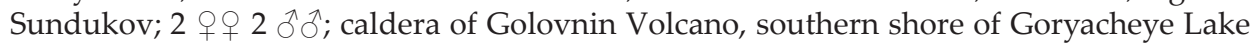

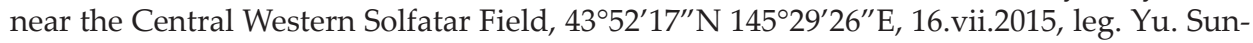

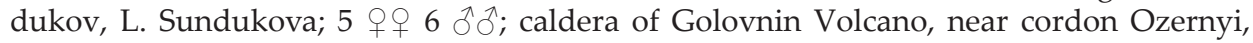

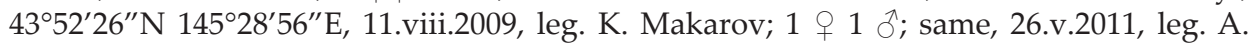

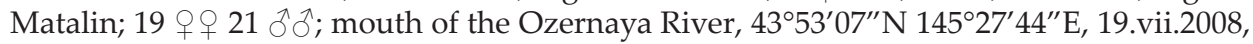

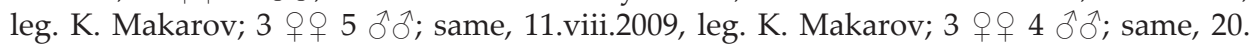

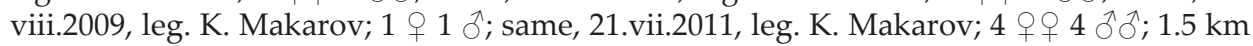
south-west mouth of the Ozernaya River, $43^{\circ} 52^{\prime} 27^{\prime \prime} \mathrm{N} 145^{\circ} 27^{\prime} 16^{\prime \prime} \mathrm{E}$, 26.vii.2011, leg. K. Ma-

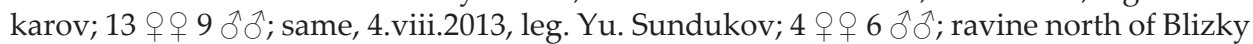

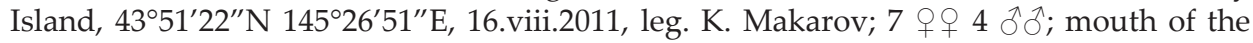

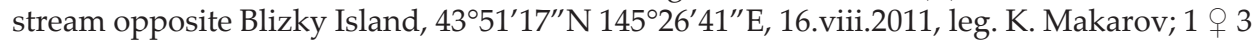

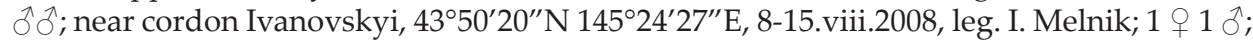
stream mouth $2 \mathrm{~km}$ south of Ivanovskyi Cape, $43^{\circ} 48^{\prime} 53^{\prime \prime} \mathrm{N} 145^{\circ} 24^{\prime} 44^{\prime \prime} \mathrm{E}$, 18.viii.2011, leg. K. Makarov; 1 ; ; waterfall $2.5 \mathrm{~km}$ south of Ivanovskyi Cape, $43^{\circ} 49^{\prime} 04^{\prime \prime} \mathrm{N} 145^{\circ} 24^{\prime} 40^{\prime \prime} \mathrm{E}, 18$.

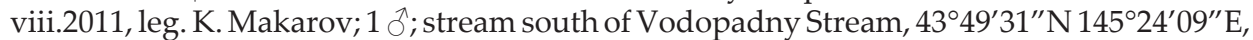
11.vi.2011, leg. A. Matalin; 7 우 1 ja ; Vodopadny Stream south of Ivanovskyi Cape,

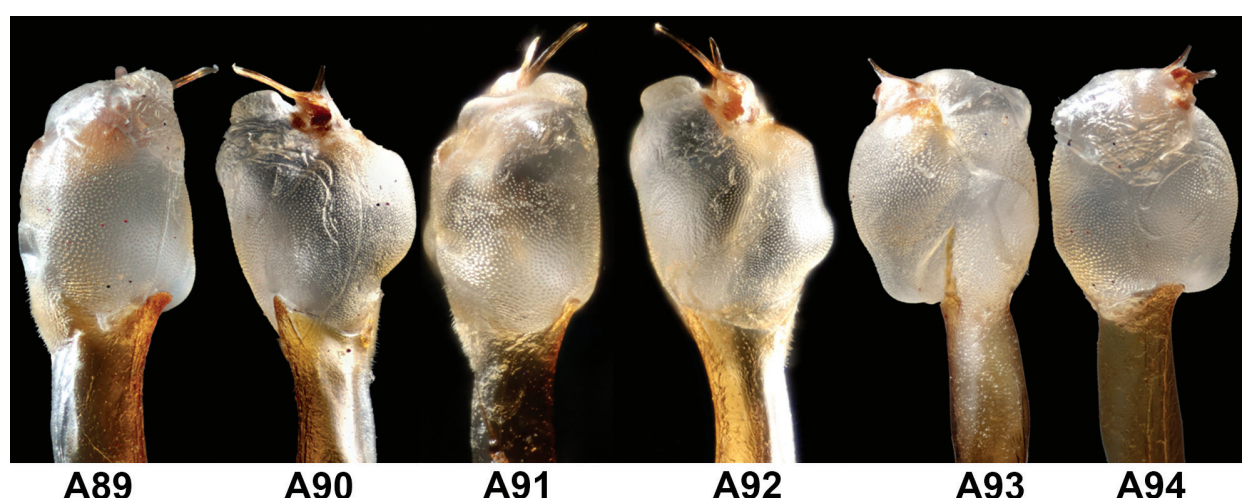

Figs A89-A94. Variability of the endophallus (shape of the sac and distal parts of the main sclerite and lamina 2) B. dolorosum: A89, A90 = Kunashir Isl., $2.5 \mathrm{~km}$ NW of Cape Nelyudimyi; A91, A92 = Kunashir Isl., caldera of Golovnin Volcano, solfatara field "Cherepakhovoye"; A93, A94 = Kunashir Isl., Dokuchaeva Mt. Ridge, solfatara field "Bolshoye" 
$43^{\circ} 49^{\prime} 20^{\prime \prime} \mathrm{N} 145^{\circ} 24^{\prime} 56^{\prime \prime} \mathrm{E}, 13 . v i i i .2008$, leg. I. Melnik; 3 q 91 ơ; same, 15.v.2011, leg. A. Mata-

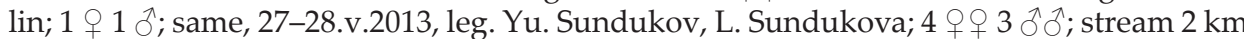

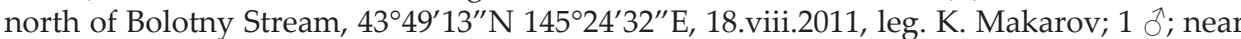
Dubovoe Vill., $43^{\circ} 45^{\prime} 58^{\prime \prime} \mathrm{N} 145^{\circ} 29^{\prime} 38^{\prime \prime} \mathrm{E}$, 21.viii.2017, leg. K. Makarov; 1 ㅇ.

Sakhalin Isl.: Chekhov Mountain, 1.vii.1986, leg. E.Nesterov; 1 đ; Aniva district,

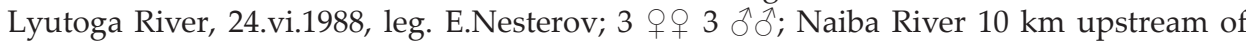
Bykovo, 6-10.viii.1991, leg. V. Grachev; 1 ; ; the Khondasa river $15 \mathrm{~km}$ to the North-West

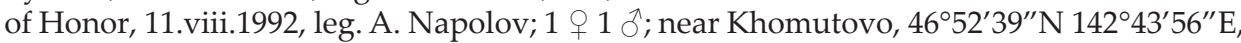

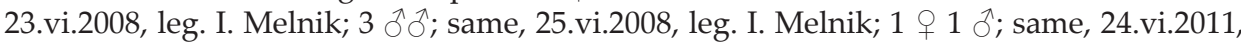

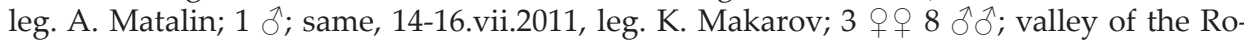
gatka River, $46^{\circ} 58^{\prime} 03^{\prime \prime} \mathrm{N} 142^{\circ} 46^{\prime} 24^{\prime \prime} \mathrm{E}$, 18.vii.2011, leg. K. Makarov; 1 q 4 ふै ơं; Vakhrushevka River near the Troitskoe Vill., 46 $55^{\prime} 48^{\prime \prime} \mathrm{N} 142^{\circ} 39^{\prime} 10^{\prime \prime} \mathrm{E}, 4 . v i i i .2018$, leg. Yu. Sundukov, L. Sundukova; 3 우 6 ठึ’; Srednyaya River near the Troitskoe Vill., riverside, $46^{\circ} 53^{\prime} 15^{\prime \prime} \mathrm{N}$

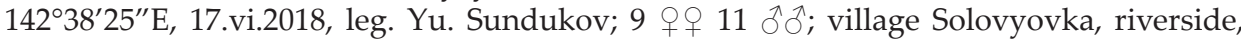

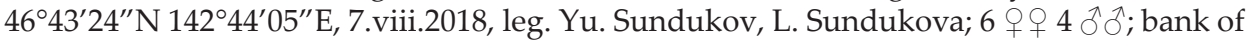
the Susuya River near Lugovoe vill., 25.vi.2011, leg. A. Matalin; 2 ô $\widehat{o}$.

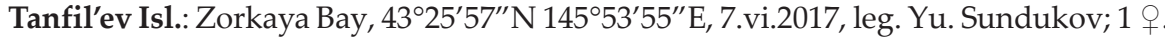

Shikotan Isl.: the Tserkovnaya Bay, stream bank, $43^{\circ} 44^{\prime} 59^{\prime \prime} \mathrm{N} 146^{\circ} 41^{\prime} 40^{\prime \prime} \mathrm{E}, 24 . v .2012$,

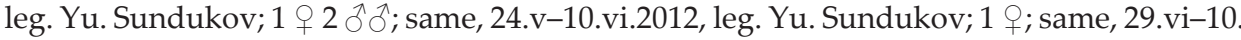

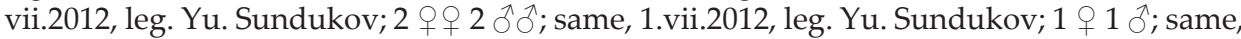

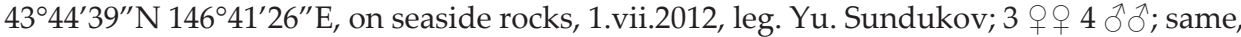
$43^{\circ} 44^{\prime} 51^{\prime \prime} \mathrm{N} 146^{\circ} 41^{\prime} 37^{\prime \prime} \mathrm{E}$, middle stream, 12.viii.2016, leg. Yu. Sundukov, L. Sundukova; 12

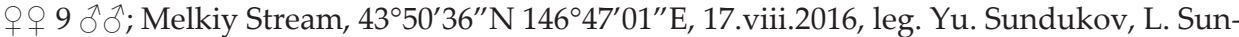

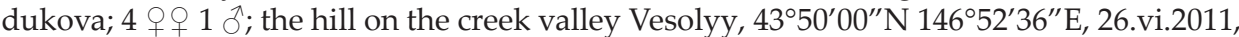

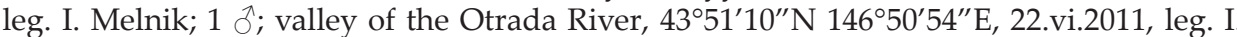

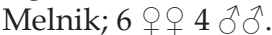

Yuriy Isl.: Shirokaya Bay, $43^{\circ} 25^{\prime} 33^{\prime \prime} \mathrm{N} 146^{\circ} 04^{\prime} 08^{\prime \prime} \mathrm{E}, 26-31 . v i i i .2016$, leg. Yu. Sundu-

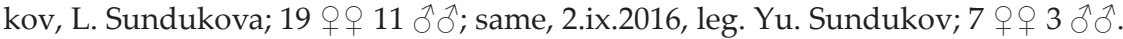

\section{Bembidion (Peryphanes) sanatum Bates, 1883} $2 ㅇ ㅗ$.

Honshu Isl.: Mt. Hikageyama Jyoushu Gunma Pref., 18.ix.1993, leg. S. Morita; $2 ð ð$

Kunashir Isl.: Kislyi Stream below hot springs, $44^{\circ} 00^{\prime} 36^{\prime \prime} \mathrm{N} 145^{\circ} 46^{\prime} 04^{\prime \prime} \mathrm{E}-43^{\circ} 59^{\prime} 56^{\prime \prime} \mathrm{N}$ $145^{\circ} 46^{\prime} 02^{\prime \prime}$ E, 18.vi.2011, leg. A. Matalin; 1 ${ }^{\top} 1$ 1 ; Mendeleev Volcano source of Kislyi Stream below the solfatara field, $43^{\circ} 59^{\prime} 46^{\prime \prime} \mathrm{N} 145^{\circ} 45^{\prime} 54^{\prime \prime} \mathrm{E}$, 3.viii.2016, leg. Yu. Sundukov, L. Sundukova; 1 1우 ; same label, 22.ix.2016, leg. Yu. Sundukov; $15 \hat{\jmath} \widehat{\partial} 17$ 우 ; same data, 15.vii.2017, leg. Yu. Sundukov, L. Sundukova; $6 \hat{\jmath}$ ำ 9 우.

\section{Poecilus (Poecilus) samurai (Lutshnik, 1916)}

Kunashir Isl.: 2.5 km NW of Cape Nelyudimyi, 44⒉ $29^{\prime} 26^{\prime \prime} \mathrm{N} 146^{\circ} 11^{\prime} 47^{\prime \prime} \mathrm{E}$, 4.viii.2013, leg. Yu. Sundukov; 1 क; mouth of the Dokuchaev River, $44^{\circ} 30^{\prime} 16^{\prime \prime} \mathrm{N} 146^{\circ} 10^{\prime} 58^{\prime \prime} \mathrm{E}$, 30.vii.2013, leg. K. Makarov; 1 ' ; Dokuchaeva Cape, Dokuchaevo [abandoned], $44^{\circ} 30^{\prime} 34^{\prime \prime} \mathrm{N}$ 14609'29" E, 31.vii.2013, leg. L. Sundukova; 1 ; ; same label, 3.viii.2013, leg. K. Makarov, Yu. Sundukov; 3 우; same label, 6.viii.2013, leg. K. Makarov; 3 $\widehat{\jmath}$; Dokuchaeva Cape, eastern coast, $44^{\circ} 30^{\prime} 21^{\prime \prime} \mathrm{N} 146^{\circ} 10^{\prime} 01^{\prime \prime} \mathrm{E}$, 1.viii.2013, leg. L. Sundukova; 1 ' ; downstream of 


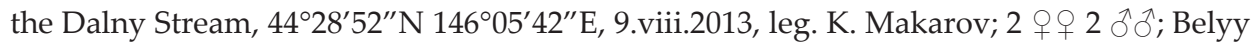
Utos Cape, $44^{\circ} 28^{\prime} 14^{\prime \prime} \mathrm{N} 146^{\circ} 04^{\prime} 45^{\prime \prime} \mathrm{E}$, 11.viii.2013, leg. Yu. Sundukov, K. Makarov; 2 우 $2 \partial^{\lambda}$; stream south of Cape Bely Utos, $44^{\circ} 27^{\prime} 46^{\prime \prime} \mathrm{N} 146^{\circ} 04^{\prime} 37^{\prime \prime} \mathrm{E}, 11 . v i i i .2013$, leg. K. Ma-

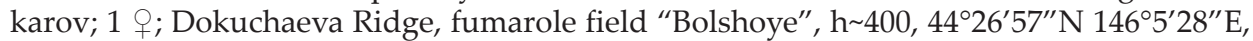

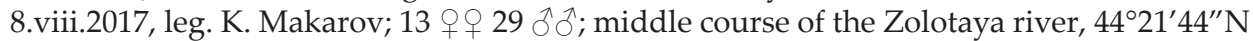

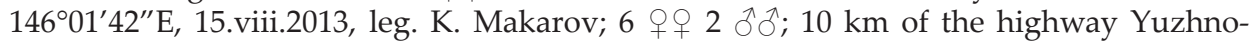
Kurilsk; Golovnino, 16.vi.1990, leg. K. Makarov; 1 ; 18 th km of the highway Yuzhno-Kurilsk - Golovnino, 44 ${ }^{\circ} 00^{\prime} 39^{\prime \prime} \mathrm{N} 145^{\circ} 42^{\prime} 04^{\prime \prime} \mathrm{E}, 12 . v i i .2018$, leg. Yu. Sundukov, L. Sundukova; 2

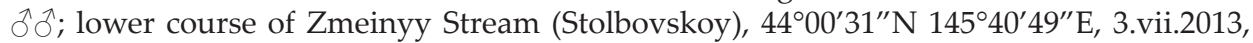

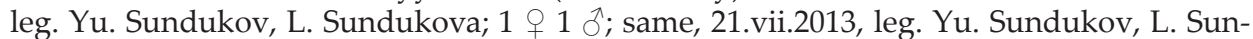

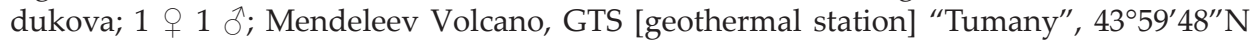
$145^{\circ} 46^{\prime} 13^{\prime \prime} \mathrm{E}, 8 . v i .2017$, leg. Yu. Sundukov; $1 \delta^{\top}$; middle course Tretyakov River, $43^{\circ} 58^{\prime} 30^{\prime \prime} \mathrm{N}$ $145^{\circ} 39^{\prime} 19^{\prime \prime}$ E, 13.viii.2011, leg. K. Makarov; 1 ; ; valley of the Asin Stream south of Tretyakovo, $43^{\circ} 58^{\prime} 52^{\prime \prime} \mathrm{N} 145^{\circ} 37^{\prime} 45^{\prime \prime} \mathrm{E}$, 2.viii.2009, leg. K. Makarov; 1 ㅇ 1 ' $;$; near mouth of Andreeva

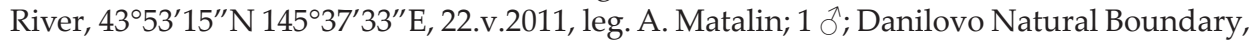

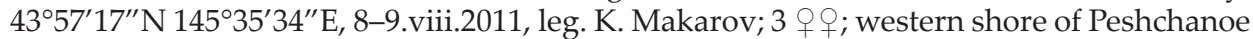
Lake, sedge meadow on the slope of the lake, $43^{\circ} 56^{\prime} 33^{\prime \prime} \mathrm{N} 145^{\circ} 35^{\prime} 20^{\prime \prime} \mathrm{E}$, 3-5.vii.2015, leg. Yu. Sundukov; $2 \hat{\delta}$; mouth of the stream between Cape Znamenka and Cape Alekhina, $43^{\circ} 56^{\prime} 00^{\prime \prime} \mathrm{N} 145^{\circ} 33^{\prime} 12^{\prime \prime} \mathrm{E}$, 4.viii.2009, leg. K. Makarov; 1 ; ; northern slope of Alekhina Cape,

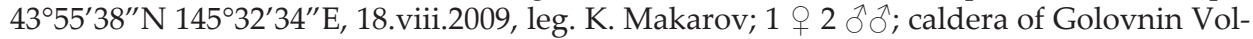

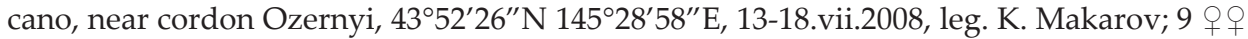

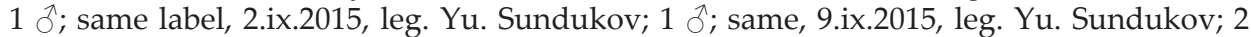

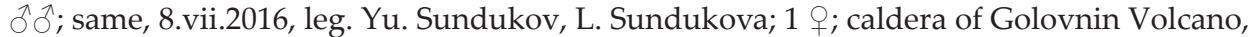
forest road of the Ozerny cordon, 43 $51^{\prime} 54^{\prime \prime} \mathrm{N} 145^{\circ} 29^{\prime} 31^{\prime \prime} \mathrm{E}, 14 . v i i .2015$, leg. Yu. Sundukov, L. Sundukova; 2 + 9 ; caldera of Golovnin Volcano, meadow south of West Central Dome, $43^{\circ} 51^{\prime} 54^{\prime \prime} \mathrm{N} 145^{\circ} 29^{\prime} 53^{\prime \prime} \mathrm{E}, 15 . v i i .2015$, leg. Yu. Sundukov, L. Sundukova; $2{ }^{\wedge} \partial^{\wedge}$; trail from the Golovnin volcano caldera to $43 \mathrm{~km}$ of the route (eastern slope of Golovnin volcano), $43^{\circ} 49^{\prime} 44^{\prime \prime} \mathrm{N} 145^{\circ} 33^{\prime} 08^{\prime \prime} \mathrm{E}-43^{\circ} 52^{\prime} 19^{\prime \prime} \mathrm{N} 145^{\circ} 29^{\prime} 43^{\prime \prime} \mathrm{E}, 30 . v i .2016$, leg. Yu. Sundukov, L. Sun-

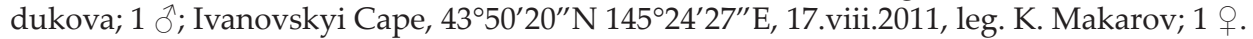

Sakhalin Isl.: env. Yuzhno-Sakhalinsk, 46 $57^{\prime} 44^{\prime \prime} \mathrm{N} 142^{\circ} 45^{\prime} 53^{\prime \prime} \mathrm{E}$, 27.viii.2008, leg.

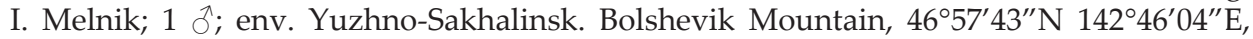
15.vii.2011, leg. K. Makarov; 1 ; ; env. Yuzhno-Sakhalinsk, left source of the Elanka River,

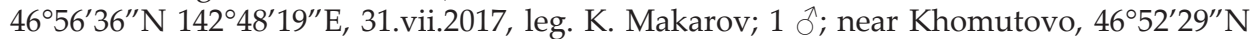

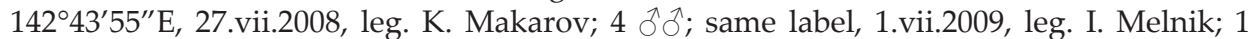
†; Naiba River 10 km above Bykovo, 6.viii.1991, leg. V. Grachev; 1 đో; same label, 6-10. viii.1991, leg. V. Zherikhin; 1 \%; same, 11-17.viii.1991, leg. V. Grachev; 1 q. 
Appendix 3. GenBank/BOLD accession numbers of COI sequences for each taxon Bembidion subgenus Ocydromus Clairville, 1806 and outgroup (subgenus Odontium LeConte, 1848).

Bembidion (Ocydromus) decorum subconvexum K. Daniel et J. Daniel, 1902 - JN171004

Bembidion (Ocydromus) decorum decorum (Panzer, 1799) - GU347079, GU347079, GU347080, GU347081, GU347082, GU347083, GU347084, GU347085, GU347086, GU347087, GU347088, HQ953381, HQ954518, HQ954566, KM442982, KM443094, KM444732, KM445300, KM447519, KU876576, KU876611, KU876614, KU876628, KU876759, KU906522, KU910828, KU917526, KU918240, MF170682, MF170683, MF170684, MF170685

Bembidion (Ocydromus) dolorosum (Motschulsky, 1860) from solfatar fields - MW240493, MW240494, MW240495, MW240496

Bembidion (Ocydromus) dolorosum (Motschulsky, 1860) from other habitats - MW240497, MW240498, MW240499, MW240500, MW240501, MW240502

Bembidion (Ocydromus) grapii Gyllenhal, 1827 - BETN4356-19, INRMA1455-14, JF888233, JN171043，KJ964478, KR490216, KR490777, KT959682, KT959846, KT959881, KU874327, KU874328, KU874329, MG056889

Bembidion (Ocydromus) lugubre LeConte, 1857 - BBCCA469-12, HM433259, HM433264, JN171062

Bembidion (Ocydromus) modestum (Fabricius, 1801) - HQ954512, JF889194, JF889195, JF889196, JF889197， JF889198， JN171071， KM439802， KM442245， KM443902, KM444358, KM447325, KM449092, KM449261, KU876577, KU876677, KU876712

Bembidion (Ocydromus) sarpedon Casey, 1918 - JN171106, KU233815, KU233818, KU233823, KU233827

Bembidion (Ocydromus) saxatile Gyllenhal, 1827 - KJ962084, KJ962534, KJ962627, KJ962713, KJ962861, KJ962948, KJ966772, KM444848，KU906432，KU907499, KU907637, KU910139, KU914526, KU915056, KU916970

Bembidion (Ocydromus) scopulinum (Kirby, 1837) - HQ551623, JN171110, JX259800, KU874366, KU874367

Bembidion (Ocydromus) transversale Dejean, 1831 - KJ203568, KU233802, KU233814

Bembidion (Ocydromus) yukonum Fall, 1926 - KU874373, KU874374, NEONU1963-13

Bembidion (Odontium) aenulum Hayward, 1901 - DNA1622

Bembidion (Odontium) paraenulum Maddison, 2009 - DNA1620

Bembidion (Odontium) persimile A. Morawitz, 1862 - DNA1288

Bembidion (Odontium) striatum (Fabricius, 1792) - BFB_Col_FK_9026 


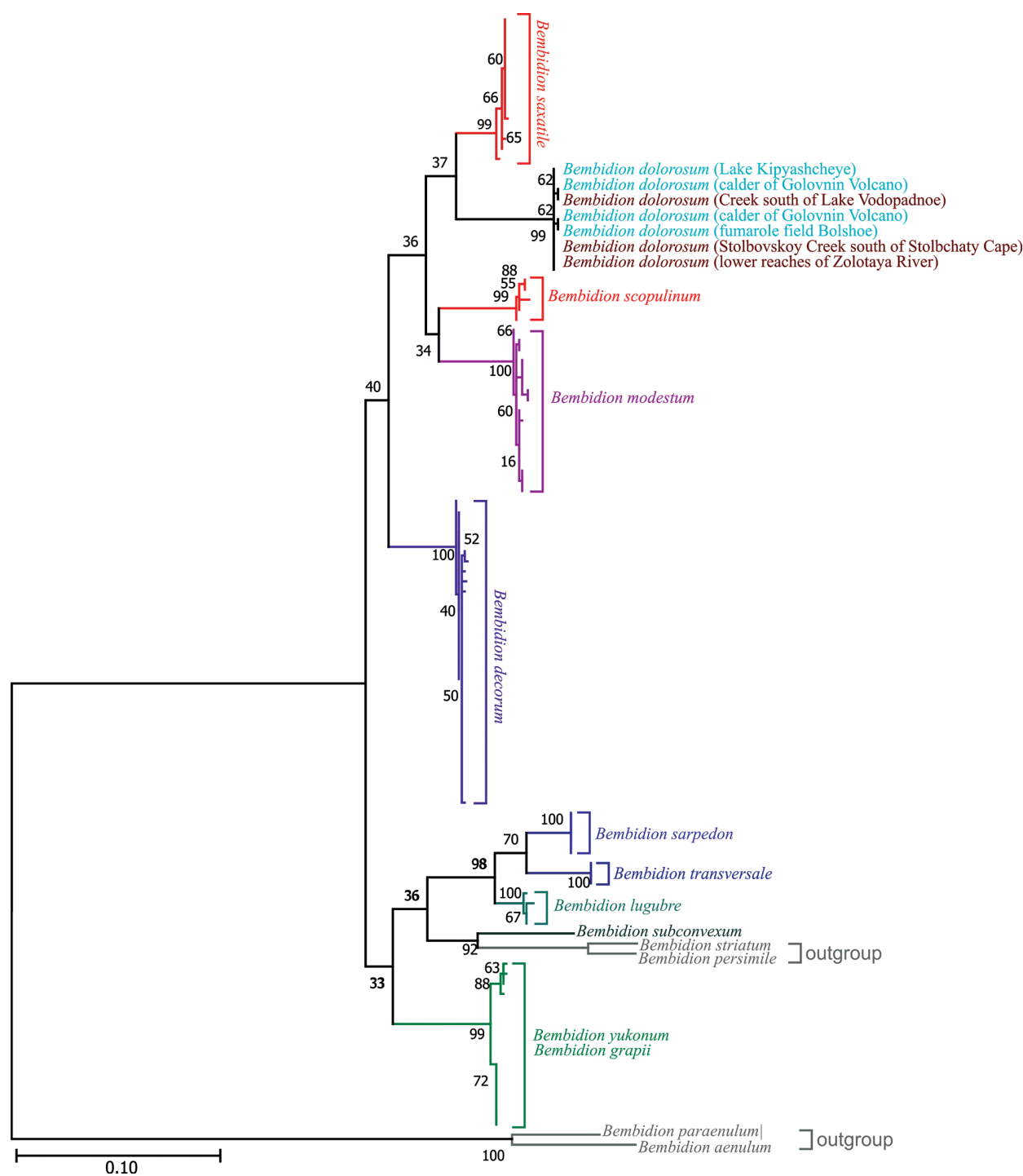

Fig. A95. Position of B. dolorosum within Ocydromus subgenus. The phylogenetic tree of COI was inferred by the maximum likelihood method (the tree with the highest log likelihood -4576.41 is shown) using 1000 replicates (numbers next to the branching points indicate the relative bootstrap-support). Bembidion species are indicated by the color code.

GenBank accession numbers for each isolate indicates in Appendix 3 

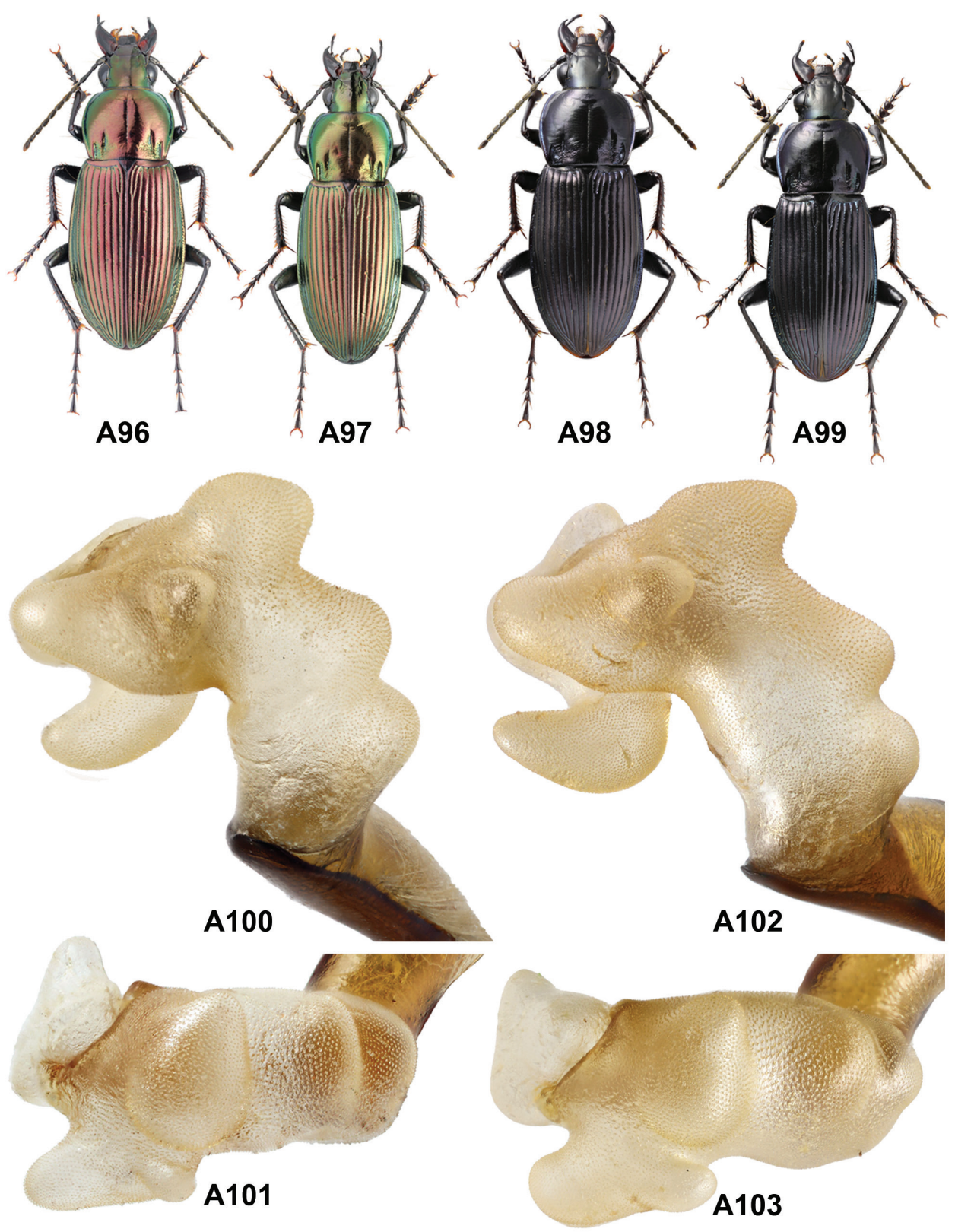

Figs A96-A103. Variation of Poecilus samurai on Kunashir Island: A96, A98 = females, habitus; A97, A99 = male, habitus; A100-A103 = endophallus, lateral (A100, A102) and dorsal (A101, A103); A96-A97, A100-A101 = specimens from common habitats; A98-A99, A102A103 = specimens, living on solfatara field "Bolshoye", Dokuchaeva Mt. Ridge 


\section{Appendix 4. A list of ground beetles found in the solfatara fields of Kunashir Island}

*Cicindela (Cicindela) sachalinensis A. Morawitz, 1862

${ }^{*}$ Cylindera (Eugrapha) elisae (Motschulsky, 1859)

Nebria (Reductonebria) ochotica R.F. Sahlberg, 1844

Carabus (Carabus) arvensis Herbst, 1784

C. (Leptocarabus) arboreus Lewis, 1882

C. (Megodontus) kolbei aino Rost, 1908

Elaphrus (Elaphrus) riparius (Linnaeus, 1758)

Clivina (Clivina) fossor sachalinica Nakane, 1952

Bembidion (Asioperyphus) bandotaro Morita, 1991

B. (Bembidion) paediscum Bates, 1883

${ }^{*}$ B. (Ocydromus) dolorosum (Motschulsky, 1860)

${ }^{*} B$. (Peryphanes) sanatum Bates, 1883

B. (Peryphus) poppii pohlai Kirschenhofer, 1984

B. (Plataphus) tetraporum Bates, 1883

*Poecilus (Poecilus) samurai (Lutshnik, 1916)

Pterostichus (Bothriopterus) adstrictus Eschscholtz, 1823

Pt. (B.) subovatus (Motschulsky, 1861)

Pt. (Euferonia) thunbergi A. Morawitz, 1862

Pt. (Phonias) diligens (Sturm, 1824)

Pt. (Pseudomaseus) rhaeticus Heer, 1837

Agonum (Europhilus) subtruncatum (Motschulsky, 1860)

Eucolpodes japonicum (Motschulsky, 1861)

Glaucagonum sylphis (Bates, 1873)

Synuchus (Synuchus) arcuaticollis (Motschulsky, 1861)

S. (S.) melantho (Bates, 1883)

Stenolophus (Stenolophus) propinquus A. Morawitz, 1862

Demetrias (Demetrias) amurensis Motschulsky, 1861

Dromius (Klepterus) prolixus Bates, 1883

Lebidia octoguttata A. Morawitz, 1862

${ }^{*}$ marked species that constantly live here. 
Appendix 5. Overall MANOVA results showing the dependence of body length and relative width of the pronotum on temperature and $\mathrm{pH}$ of water bodies at the banks inhabited by B. dolorosum.

\begin{tabular}{|c|c|c|c|c|c|c|}
\hline \multicolumn{7}{|c|}{ Tests on independent variables } \\
\hline & $\begin{array}{l}\text { Wilks } \\
\text { lambda }\end{array}$ & $\mathrm{F}$ & df1 & df2 & $\mathrm{p}$ & \\
\hline $\mathrm{T}^{\circ} \mathrm{C}$ & 0.9759 & 3.67 & 2 & 297 & 0.02665 & \\
\hline $\mathrm{pH}$ & 0.5765 & 109.1 & 2 & 297 & 3.007E-36 & \\
\hline \multicolumn{7}{|c|}{ Tests on dependent variables } \\
\hline & $\mathrm{R}^{2}$ & $\mathrm{~F}$ & df1 & df2 & $\mathrm{p}$ & \\
\hline EW/PW & 0.3181 & 69.51 & 2 & 298 & $1.672 \mathrm{E}-25$ & \\
\hline L_abs & 0.5656 & 194 & 2 & 298 & $1.104 \mathrm{E}-54$ & \\
\hline \multicolumn{7}{|c|}{ Regression coefficients and statistics } \\
\hline & & Coeff. & Std.err. & $\mathrm{t}$ & $\mathrm{p}$ & $\mathrm{R}^{2}$ \\
\hline \multirow[t]{3}{*}{ EW/PW } & Constant & 1.4835 & 0.014313 & 103.64 & $8.4635 \mathrm{E}-236$ & \\
\hline & $\mathrm{T}^{\circ} \mathrm{C}$ & -0.00038661 & 0.00024508 & -1.5775 & 0.11574 & 0.15846 \\
\hline & $\mathrm{pH}$ & 0.016147 & 0.0019331 & 8.353 & 2.5487E-15 & 0.31242 \\
\hline \multirow[t]{3}{*}{ L_abs } & Constant & 4.4875 & 0.087028 & 51.564 & $1.5588 \mathrm{E}-150$ & \\
\hline & $\mathrm{T}^{\circ} \mathrm{C}$ & -0.0038028 & 0.0014901 & -2.552 & 0.011211 & 0.27933 \\
\hline & $\mathrm{pH}$ & 0.16472 & 0.011754 & 14.014 & $1.2665 \mathrm{E}-34$ & 0.55612 \\
\hline
\end{tabular}

\section{References cited in the Appendix}

Bulgakov, R. F. (1994): The history of the development of the southern islands of the Great Kurile chain in the Pleistocene. - Abstract of a dissertation for the degree of a candidate of geographical sciences. - MSU, Moscow, 22 pp. [In Russian]

GanzeY, K. S. (2004): Landscape differentiation of the Mendeleev volcano (Kunashir Island, southern Kurils). - Geoekologiya i problemy ratsional'nogo prirodopol'zovaniya na Dal'nem Vostoke: Materialy konferentsii. Vladivostok. Pp. 74-77. [In Russian]

Kozlov, D. N. \& Zharkov, R. V. (2010): Morphology and genesis of the lakes of Golovnin and Zavaritsky calderal complexes (Kuril Islands). - Vestnik DVO RAN 3: 103-106.

Lebedev, L. M., Shurmanov, L. P. \& Nikitina, I. B. (1977): New data on the mineralogy of a sulfide lode on the northeastern slope of Mendeleev Volcano. Pp. 104-122. In: LebeDEv, L. M. (ed.): Modern hydrothermal vents and mineral formation. - Nauka, Moscow. [In Russian]

Manko, Yu. D. \& Sidelnikov, A. N. (1989): The influence of volcanism on vegetation. - The Far Eastern Branch of the Soviet Academy of Sciences Press, Vladivostok, 161 pp. [In Russian] 
Markhinin, E. K. \& Stratula, D. S. (1977): Hydrotherms of Kuril Islands. - Nauka, Moscow, 212 pp. [In Russian]

Melekestsev, I. V., Braitseva, O. A. \& Sulerzhitskiy, L. D. (1988): Catastrophic explosive volcanic eruptions in Kamchatka and the Kurile Islands in the Late Pleistocene early Holocene time. - Doklady Akademii nauk SSSR 300(1): 175-181. [In Russian]

Milne, J. (1896): The volcanoes of Japan. - Transactions of the Seismologiocal Society of Japan 9(2): 539-548.

Razjigaeva, N. G. (2005): Evolution of Quaternary situations of sediment accumulation in the islands of East Asia. - Avtoreferat dissertatsii na soiskanie nauchnoy stepeni doktora geograficheskikh nauk. - St. Petersburg, 43 pp. [In Russian]

Sundukov, Yu. N. \& Kozlovski, E. E. (2017): A newly described group of thermal springs and solfatar fields on the western slope of Dokuchaev Mountain Ridge, Kunashir Island. - Nature Conservation Research 2(2): 83-88. [In Russian]

Zнаккоv, R. V. (2014): Thermal springs of the South Kuril Islands. - Dalnauka, Vladivostok, 378 pp. [In Russian]

Zotov, A. V., Sorokin, V. I. \& Nikitina, I. B. (1988): Some peculiarities of the modern hydrothermal activity in the caldera of Golovnin volcano (Kunashir Island). Pp. 54-69. In: Chuknrov, F. V. (ed.): Sovremennye gidrotermy i mineraloobrazovanie. - Nauka, Moscow. [In Russian] 